\title{
A Safety and Economic Study of Special Trains for Shipment of Spent Fuel
}

December 1977

Prepared for the

U.S. Department of Energy

under Contract EY-76-C-06-1830 


\title{
NOTICE
}

This report was prepared as an account of work sponsored by the United States Government. Neither the United States nor the Department of Energy, nor any of their employees, nor any of their contractors. subcontractors, or their employees, makes any warranty, express or implied, or assumes any legal liability or responsibility for the accuracy, completeness or usefulness of any information, apparatus, product or process disclosed, or represents that its use would not infringe privately owned rights.

The views, opinions and conclusions contained in this report are those of the contractor and do not necessarily represent those of the United States Covernment or the United States Department of Energy.

\author{
PACIFIC NORTHWEST LABORATORY \\ operated by \\ BATTELLE \\ for the \\ UNITED STATES DEPARTMENT OF ENERGY \\ Under Contraci EY-76-C-06-1830
}

\begin{tabular}{|c|c|}
\hline \multicolumn{2}{|c|}{$\begin{array}{c}\text { Printed in the United States of America } \\
\text { Available from } \\
\text { National Technical Information Service } \\
\text { United States Department of Commerce } \\
5285 \text { Port Royal Road } \\
\text { Springileld, Virginia } 22159\end{array}$} \\
\hline Printed Cc & $\because$ Microfiche $53.0 \mathrm{x}$ \\
\hline "Pages & $\begin{array}{c}\text { NTIS } \\
\text { Selling Price }\end{array}$ \\
\hline $001-025$ & $\$ 4.50$ \\
\hline $026-050$ & 55.00 \\
\hline $051-075$ & 55.50 \\
\hline $076-100$ & $\$ 6.00$ \\
\hline $101-125$ & $\$ 6.30$ \\
\hline $126-150$ & 57.00 \\
\hline $151-175$ & 57.75 \\
\hline $176-290$ & $\$ 8.50$ \\
\hline $201-225$ & $\$ 8.75$ \\
\hline $226-250$ & $\$ 9.00$ \\
\hline $251-275$ & $\$ 10,00$ \\
\hline $276-300$ & $\$ 70.25$ \\
\hline
\end{tabular}


A SAFETY AND ECONOMIC STUDY OF SPECIAL TRAINS FOR SHIPMENT OF SPENT FUEL

by

Technical Contributors

W.V. Loscutoff

E.S. Murphy

L.L. Clark

R.W. McKee

R.J. Hal1

Program Coordinator

R.E. Rhoads

December 1977

Battelle

Pacific Northwest Laboratories

Richland, Washington 99352 


\section{ACKNOWLEDGEMENTS}

The authors would like to acknowledge Dr. K. P. Furber of the Association of American Railroads, Mr. J. G. German of the Missouri-Pacific Railroad and Mr. D. B. Phillips of the Southern Railway System for reviewing the draft versions of this document and providing valuable comments and assistance toward the development of this final report. 
9 


\section{SUMMARY}

Spent fuel from nuclear reactors has been transported in routine commerce in the U.S. for over 25 years. During this period, no accident has occurred that resulted in the release of radioactive material from a spent fuel cask. By 1986, the annual rate of spent fuel shipments by rail is expected to be nearly 20 percent of the total shipments during the last 25 years. Because of this increased shipping rate, the railroad industry contends that the transportation environment for spent fuel shipments must be controlled to maintain this excellent safety record. To provide this control over the transportation environment, the Association of American Railroads (AAR) has proposed that all spent fuel be handled in special train service. A set of operating practices for spent fuel special trains has been proposed that includes a $35 \mathrm{mph}$ maximum speed restriction, a passing restriction and a no-other-freight restriction. The purpose of this study was to evaluate the potential effects of these restrictions on the safety and cost of shipping spent fuel by train. The analysis is based on estimated quantities of spent fuel transported in 1986.

Data were not available to directly compare the safety of special trains and conventional freight trains. The potential effects of the spent fuel special train operating restrictions were examined using data from the Federal Railroad Administration for freight train accidents that occurred from 1972-1974. Based on this data, evaluations were made on the relative safety of special trains and conventional trains using accident frequency and severity as comparative measures. Dollar damage to railroad equipment during an accident was selected as the best available measure of accident severity.

Increased cask and equipment damage (expressed in terms of dollar damage) does not necessarily represent decreased safety to the general public. Threshold levels of accident stresses (e.g., impact and puncture forces and fire temperature and duration) are required to compromise the integrity of spent fuel casks before any of the contained radioactive materials could 
be released. Analytical studies, scale model tests and full scale tests of spent fuel casks in transportation accident situations have demonstrated that casks will survive severe accident conditions. Based upon these studies and tests, it is expected that the casks would maintain their integrity even at the highest level of dollar damage (greater than $\$ 250,000$ ) investigated in this study. Additionally, accidents that could compromise cask containment integrity are expected to occur very infrequently. Analyses of accident severity using dollar damage as a basis can provide some insights into the potential safety benefits of the proposed special train requirements but care should be taken in the strict use of the results since there is no direct correlation between dollar damage and cask failure threshold levels.

The potential effect of the speed restriction was investigated by analyzing data on the frequencies of train accidents as a function of train speed and accident severity (dollar damage). Data for all train accidents and for head-on and rear-end collision accidents only were analyzed. It was found that about 80 percent of all freight train accidents occur at speeds less than $35 \mathrm{mph}$. It was also estimated that the accident rate (accidents/ mile traveled) for travel at speeds below $35 \mathrm{mph}$ was more than double the accident rate for travel at speeds above $35 \mathrm{mph}$. This suggests that accidentfactors are greatest in those portions of the railroad system that have speed limits below $35 \mathrm{mph}$. Thus, it appears that speed restrictions necessary for safety already exist and that additional speed restrictions may not significantly affect the safety of the current shipping system.

Three levels of dollar damage were investigated to determine the effect of the speed restriction on the frequency of involvement in severe accidents. The three levels of dollar damage used - \$75,000, $\$ 150,000$ and $\$ 250,000$ represent, respectively, 7 percent, 3 percent and 1 percent of all freight train accidents. It was determined that about 58 percent of accidents resulting in $\$ 75,000$ or more damage; about 70 percent of all accidents resulting in $\$ 150,000$ damage or more; and 77 percent of all accidents resulting in \$250,000 damage or more, occur at speeds above $35 \mathrm{mph}$. This indicates that accidents at speeds above $35 \mathrm{mph}$ are more likely to result in high 
dollar damage than accidents at lower speeds. The $35 \mathrm{mph}$ speed restriction does, therefore, appear to have some potential for reducing the frequency of involvement of a spent fuel cask in high dollar damage accidents, but it would not eliminate involvement in severe accidents. In addition, the measure of accident severity being used is total dollar damage in the accident. Much of the apparent benefit of the speed restriction in reducing the frequency of severe accidents may lie in the fact that, on the average, more cars are involved per accident in accidents at higher speeds. It was found that the average dollar damage per car is not strongly dependent on the speed at which the accident occurs. This may be partly explained by the fact that only the first few cars involved in an accident experience the maximum impact forces. After initial contact, the relative speed of other cars involved in the accident is reduced.

Data for head-on, rear-end and side-or-raking collision accidents also show that the speed restriction has only a limited potential for improving the safety of spent fuel transportation. It was found that 20 percent of collision accidents resulting in $\$ 75,000$ damage or more; 18 percent of collision accidents resulting in $\$ 150,000$ damage or more and 23 percent of collision accidents resulting in $\$ 250,000$ damage or more occur at speeds greater than $35 \mathrm{mph}$. Based on this data, imposition of the $35 \mathrm{mph}$ speed restriction could have the potential to eliminate a maximum of about 20 percent of the most severe head-on, rear-end and side-or-raking collision accidents.

The effect of the passing restriction was investigated by analyzing data for side or raking accidents. This restriction may be redundant, since on many rail lines, one train is stopped on a siding when a passing situation occurs. The restriction would only have an effect on the railroad lines with double main tracks. These lines presently comprise about 11 percent of the total length of roadway for Class I line haul railroads. It was c found that currently about 71 percent of side or raking accidents occur with one train standing. The passing restriction, therefore, appears to have a negligible effect on the safety of spent fuel transportation. 
The effect of the no-other-freight restriction was investigated by examining the expected frequency of exposure of a spent fuel cask to fires lasting longer than 30 minutes. This fire duration was selected because as part of the licensing process, spent fuel casks must be shown to be capable of maintaining their containment integrity after exposure to a $1475^{\circ} \mathrm{F}$ fire for 30 minutes. Although exposure to fires of longer duration does not necessarily imply a release of radioactive materials, the licensing standard does provide a basis for comparing the fire hazard in regular train service with special train service. It was estimated that for 1986 shipping levels, a spent fuel cask carried in regular train service might be exposed to a fire lasting longer than 30 minutes once in 1300 years. For casks carried in special train service, many of the potential fire sources present in a regular train are eliminated. The casks may still be exposed to locomotive fires or fires from other sources, however. It was estimated that for 1986 shipping leve1s, a spent fuel cask carried in special trains might be exposed to a fire lasting longer than 30 minutes once in 1600 years. The no-other-freight restriction appears to have only a small effect on the safety of shipping spent fuel by rail.

The economics analysis examined the differences in costs between conventional freight and special train shipments from two viewpoints: costs to the shipper and revenues to the railroads. Average shipper costs were calculated for a set of reference shipping parameters. Average shipping costs for conventional freight train service were estimated to be $\$ 15.50$ per $\mathrm{kgU}$ ( $\mathrm{kg}$ of uranium in the fuel) and $\$ 23.50$ per $\mathrm{kgU}$ if special trains were used. A sensitivity analysis was performed to determine the relative importance of the reference shipping parameters and to evaluate the effects of changes in the basic cost assumptions. It was found that the results of the analysis were most sensitive to the assumptions regarding cask use charges, cask turnaround time, average train speed and special train cost charges. Analysis of possible variations in these parameters showed that the cost of shipping spent fuel in special train service could range from $20 \%$ 1ower to $200 \%$ higher than the cost of shipping the fuel in regular train service. It was also found that for the reference shipping parameters, the cost of shipping spent fuel in special train service is minimized if three spent fuel casks are shipped in each special train. 
Analysis of railroad revenues (freight and special train charges) showed that special train requirements will probably double average railroad revenues for shipment of spent fuel. The revenues vary from about 50 percent increase (for five spent fuel casks per special train) to 250 percent increase (for one spent fuel cask per special train).

The results of the study indicate that transportation of spent fuel in special trains under the operating restrictions proposed by the AAR has the potential to substantially increase the costs of spent fuel transportation. Although special trains could offer economic or logistic advantages for some shippers, analysis of available data does not indicate any clearcut advantage of the special train operating practices from a safety standpoint. 


$$
\checkmark
$$




\section{CONTENTS}

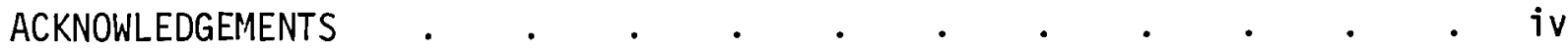

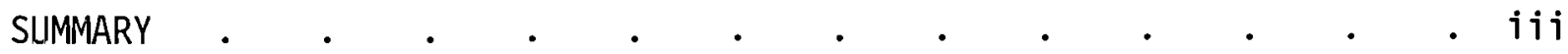

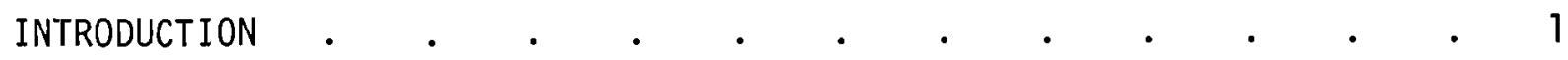

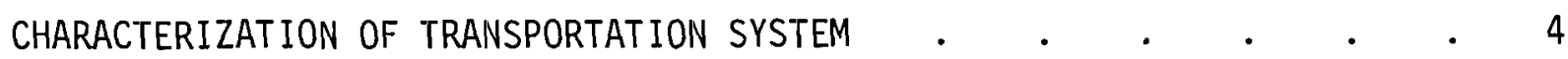

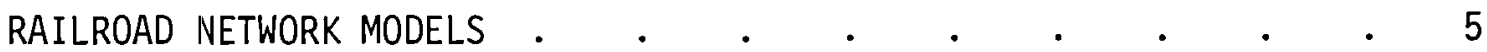

SPENT FUEL SHIPMENT CHARACTERISTICS • • • • • • • • 6

Shipping Casks .

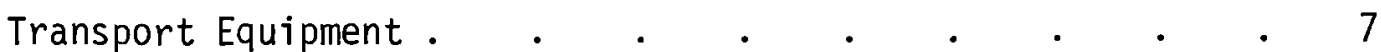

Accident-Resistance of Spent Fuel Casks . . . . . . $\quad$. 8

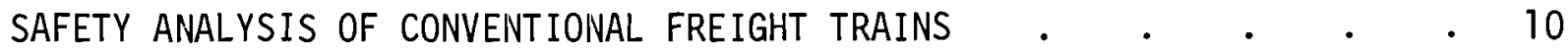

EXPERIENCE WITH SPECIAL TRAINS $\quad \cdot \quad \cdot \quad \cdot \quad \cdot \quad \cdot \quad \cdot \quad \cdot \quad \cdot 11$

TRAIN ACCIDENT STATISTICS $\quad \cdot \quad \cdot \quad \cdot \quad \cdot \quad \cdot \quad \cdot \quad \cdot \quad \cdot \quad \cdot 12$

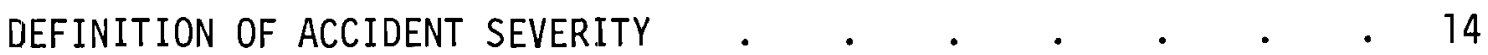

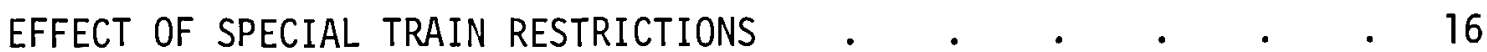

Effect of Speed Restriction . . . . . . . . . 16

Effect of Passing Restriction . . . . . . . 27

Effect of No-0ther-Freight Restriction . . . . . . 28

Considerations in the Safety of

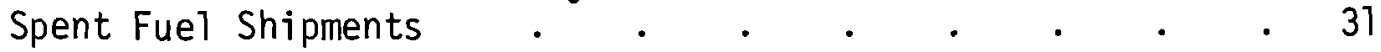

ECONOMIC IMPACT OF SPECIAL TRAIN REQUIREMENTS

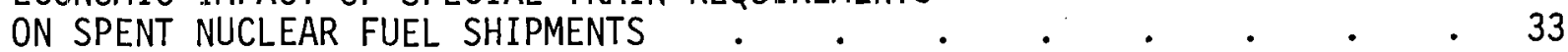

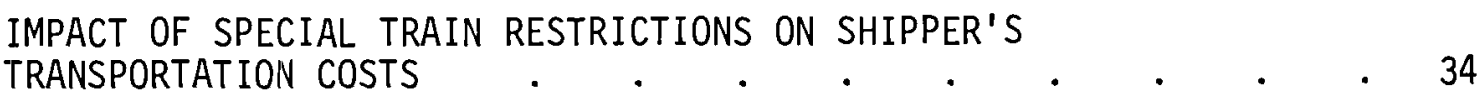

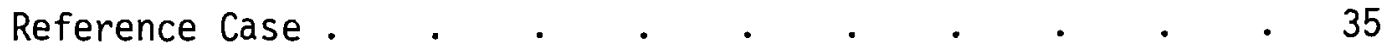

Sensitivity of the Study Parameters . . . . . . 38

ANALYSIS OF COST PARAMETERS $\quad . \quad \cdot \quad \cdot \quad \cdot \quad \cdot \quad \cdot \quad \cdot \quad \cdot 39$

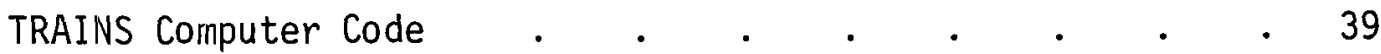

Effect of Multiple Cask Shipments . . . . . . . 40

Effect of Cask Size . . . . . . . . . . . . 40

Effect of Cask Terminal Time . . . . . . . . 43

Effect of Cask Use Charges . . . . . . . . . . 44 
Effect of Train Speed . . . . . . . . . 44

Effect of Special Train Charges . . . . . . 46

Range of Unit Costs for Special Trains . . . . . 47

IMPACT OF SPECIAL TRAIN REQUIREMENTS ON

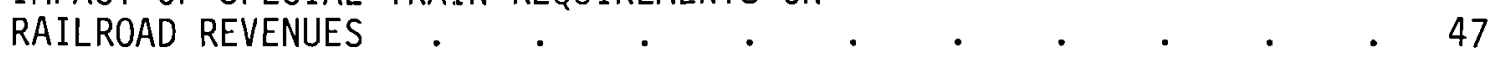

SUMMARY OF ECONOMIC ANALYSIS . $. \quad . \quad . \quad . \quad . \quad . \quad . \quad 50$

REFERENCES . . . . . . . . . . . . Ref-1

APPENDIX A - TRANSPORT NETWORK MODEL FOR SPENT
FUEL SHIPMENTS IN $1986 . .$.

APPENDIX B - FREIGHT TRAIN ACCIDENT DATA . . . . . . . . B-1

APPENDIX C - TRAINS - COMPUTER CODE FOR ECONOMIC ANALYSIS . . . C C-1

APPENDIX D - RAILROAD CHARGES APPLICABLE TO SHIPMENT

OF SPENT NUCLEAR FUEL ELEMENTS . . . . . . . . . . 


\section{FIGURES}

1 Accident Frequency Plotted as a Function of Train Speed for 1972-1974 (17,153 Accidents) . . . . . . 18

2 Accident Distribution Versus Train Speed for Freight Train Accidents with Damage Exceeding \$75,000

(Class I Line-Haul Railroads, 1972-1974)

3 Accident Distribution Versus Train Speed for Freight

Train Accidents with Damage Exceeding \$150,000

(Class I Line-Haul Railroads, 1972-1974) . . . . . . 20

4 Accident Distribution Versus Train Speed for Freight

Train Accidents with Damage Exceeding \$250,000

(Class I Line-Haul Railroads, 1972-1974) . . . . . 20

5 Distribution of Dollar Damage per Car

as a Function of Train Speed . . . . . . . . 23

6 Estimated Probability per car mile that a Spent Fuel

Cask in Normal Train Service will be involved in a

Fire with a Duration Exceeding that shown . . . . . 29

7 Average Unit Cost of Spent Fuel Rail

Shipments to Reprocessors in 1986 . . . . . . . 36

8 Effect of Multiple Cask Shipments for Selected Reactor

Destinations (Special Train Both Directions) . . . . . 41

9 Effect of Cask Size on 1986 Shipping Costs . . . . . . 43

10 Effect of Cask Terminal Time on 1986

Shipping Costs to Barnwe11, SC . . . . . . . . 44

Effect of Cask Use Charges on 1986
Shipping Costs to Barnwel1, SC . . . . . . . . 4 45

12 Effect of Train Speed on Shipments to Barnwe11, SC . . . 45

13 Effect of Special Train Charges . . . . . . . 46

14 Estimated Maximum and Minimum Costs of Using

Special Trains Shown with Reference Case Costs . . . . 48 


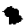
5 


\section{$\underline{\text { TABLES }}$}

1 Estimated Shipments of Spent Fuel to Reprocessing

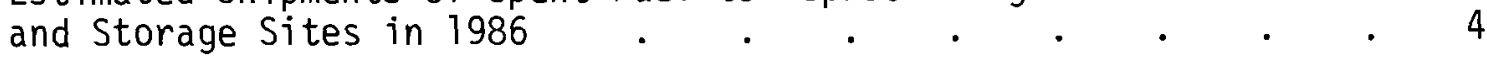

2 Freight Train Accident Rates for 1972-1974, Class I Line-Haul Railroads . . . . . . . . 13

3 Number of Freight Train Accidents by Year and by Class of Accident, Class I Line-Haul Railroads Only . . . . . 14

4 Reference Cask Parameters . . . . . . . . . . 34

5 Rail Shipping Cost Summary for 1986 Reference Case . . . 35

6 Average Costs for Spent Fuel Rail Shipments to Reprocessing Plants in 1986 . . . . . . . . 37

7 Sensitivity Analysis for Spent Fuel Shipping Parameters, Special Train Required in Both Directions (Based on Barnwel1, SC Data). . . . . . 38

8 Sample Reactor-Destination Parameters . . . . . . . 41

9 Effect of Multiple Cask Shipments Using Special Train Both Ways. . . . . . . . . 42

Parameter Values for High, Low and Most Likely
(Reference) Unit Costs for Special Trains . . . . . 48

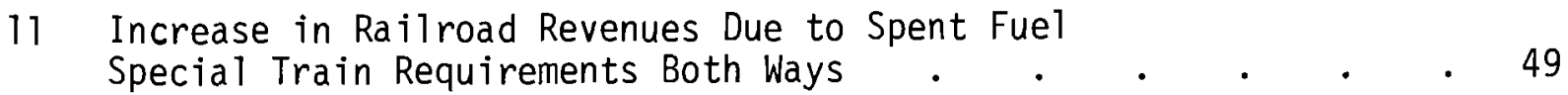




\section{INTRODUCTION}

The nuclear fuel cycle involves a variety of operations (e.g., mining, enrichment, fuel manufacture, power production, reprocessing and waste storage) which are carried out at diverse geographic locations. Proper functioning of the fuel cycle requires transportation of nuclear materials in a variety of physical and chemical forms between these facilities.

Shipments of nuclear materials are not significantly different from shipments of other hazardous materials that move in routine commerce via conventional transportation systems. Shipments of radioactive materials are regulated at the Federal level by the U.S. Department of Transportation (DOT) and the Nuclear Regulatory Commission (NRC). Standards and criteria for packaging and transportation are contained in Title 10 and Title 49 of the Code of Federal Regulations. $(1,2)$ The regulations primarily rely on a combination of container design and content limitations (i.e., amount of radioactive material and its level of radioactivity) to control potential radiation exposure to the public and transportation workers during shipments of radioactive materials. Containers used to transport large quantities of radioactive material, such as spent fuels are designed to provide safety for both normal and accident conditions, independent of any special handling or control of the transportation environment. Such containers are classified as Type B containers.

Radioactive materials have been transported commercially in the U.S. for over 25 years. This experience has included about 3600 shipments of spent fuel by both truck and train. ${ }^{(3)}$ During this period of transporting fuel cycle materials no one has been injured from an accidental release of radioactive materials. There have been ten transportation accidents involving Type B packages. In no case did these accidents cause loss of container integrity; there was no release of radioactive material nor any loss of shielding. 
In addition, the protection provided by Type $B$ containers has been the subject of intensive analytical studies ${ }^{(5-7)}$ and scale-model tests. $(8,9)$ Ful1-scale testing to confirm the model studies is underway. $(10,11)$ The first tests have shown that a spent fuel cask will survive 60- and $80-\mathrm{mph}$ head-on collisions into a reinforced concrete barrier without significant damage to the cask or any loss of its contents.

The railroad industry has recently suggested that additional measures are necessary to assure safe transport of spent fuel assemblies by rail. In response to that concern, the Board of Directors of the Association of American Railroads (AAR) has recommended a set of operating practices (12) intended to provide greater control of the transportation environment for the shipment of spent fuel. The proposed operating practices would require the use of special trains and special procedures for spent fuel transport. Operating procedures recommended by the AAR for transporting spent fuel in special trains differ from those for conventional freight trains by the following restrictions:

- Speed Restriction - Spent fuel special trains would not move faster than $35 \mathrm{mph}$.

- Passing Restriction - When a spent fuel special train meets, passes, or is passed by another train, one train would stand while the other moved past at a speed not to exceed $35 \mathrm{mph}$.

- No-Other-Freight Restriction - Shipments of casks containing spent fuel cores would move in trains containing no other freight.

To examine the effect of these additional restrictions on future spent fuel shipments, the Energy Research and Development Administration (ERDA) (now the Department of Energy) asked Batte11e, Pacific Northwest Laboratory (PNL) to compare and evaluate the safety and economics of spent fuel shipments by special trains relative to shipments by conventional freight trains. This report presents the results of that study.

For this study, a spent fuel special train has been defined as a conventional freight train operated under the restrictions proposed by AAR. It was also assumed that up to five cask/rail car units could be transported in one 
special train. Modification of these assumptions could change the results of the study.

The safety of special trains was investigated by analyzing data from the Federal Railroad Administration for freight train accidents occurring during the period 1972-1974. The potential safety benefits of the operating practices proposed by AAR were determined by evaluating the effect of their implementation on the frequency and severity of freight train accidents.

The economic analysis compared the cost of spent fuel shipments by special trains and by conventional freight trains. The cost comparison considered the freight tariffs, special train charges, and cask use charges. The analysis also included a sensitivity study based on varying parameters such as transit time, terminal time, cask use charges, special train charges and cask size. The comparative analysis relied on two approaches -- costs to the shipper and revenues received by the railroads. The analysis is based on the quantities of spent fuel expected to be transported in 1986. 


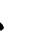

$\because$ 


\section{CHARACTERIZATION OF TRANSPORTATION SYSTEM}

The first phase of the study was to develop a transportation model consisting of spent fuel origin and destination sites, of the railroad links between the sites, and of the quantity shipped. A total of 50 railroad origin-destination links have been identified for 1986 . The total amount of spent fuel shipped by rail has been estimated at 2300 metric tons (MT) for that year. These estimates, obtained directly from potential spent fuel reprocessors, are shown in Table 1 and are based on the assumption that 230 nuclear power plants will be operating by 1986 of which 90 will ship spent fuel by rail. Two spent fuel reprocessing and storage sites are assumed. These are shown in Table 1, together with the estimated rail shipments of spent fuel.

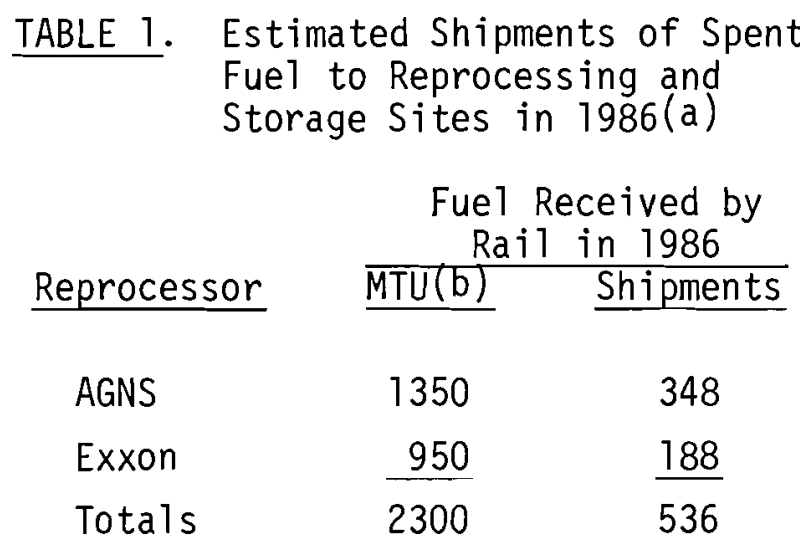

\footnotetext{
(a) Does not include the potential return of foreign (free world) discharges of spent nuclear fuel as a result of newly established government nonproliferation policy.

(b) Metric tons of uranium.
}

The model characterizes the transportation network in terms of distances, transit times, and route characteristics for conventional freight trains and spent fuel special trains. Table A-1 in Appendix A describes the assumed reactor and reprocessing rail transportation links for 1986 . The table's selection of plants and shipments to the reprocessing sites was based on (1) older plants having priority, (2) available reprocessing sites accepting shipments, and (3) availability of railroad spurs that permit use of rail casks. 
The reactor sites selected include some that are without direct rail and that require overweight truck transport to a railhead. The data for the table were generated following discussions with representatives of the spent fuel industry.

\section{RAILROAD NETWORK MODELS}

To minimize the uncertainties of the economic analysis, a detailed railroad network model that included shipping routes, transit times and other route-related variables, was used in this study. Because the number of spent fuel shipments in 1976 is small and because relatively accurate projections of shipping and receiving sites can be made for 1986, the latter period (1986) was used in the study. However, 1976 cost information and transit time estimates were used.

The railroad network for the shipment of spent fuel was based on discussions with railroad personnel and selection of most likely shipping routes using detailed rail system route maps. Appendix A presents a summary of the reactor sites and originating points, together with the number of rail shipments to be made in 1986. Table A-2 is a summary of railroad distances and corresponding transit times. The detail used in representing the railroad network facilitated economic analysis of spent fuel shipments and provided a thorough examination of the characteristics of spent fuel special trains and conventional freight trains on specific routes.

The safety analysis used a simpler model of the above railroad network since accident data is based on distances traveled. A total system shipping distance of 500,000 miles $(800,000 \mathrm{~km})$ was calculated from Table A-2 for the 536 rail shipments of spent fuel presented in Table $A-1$.

For this study, a typical conventional freight train was assumed to consist of three locomotives, 66 freight cars, and one caboose. Thirtyseven of the cars were assumed to be loaded and 29 empty, including four full and three empty tank cars. ${ }^{(13)}$ A spent fuel train was assumed to consist of one locomotive, one caboose, two buffer cars, and one to five spent fuel rail cars. 


\section{SPENT FUEL SHIPMENT CHARACTERISTICS}

The nuclear fuel for an 1100 MWe light water reactor (LWR) typically consists of 100 MTU for a pressurized water reactor (PWR) or 150 MTU for a boiling water reactor (BWR). Each year, on the average, one-third of the fuel in the PWR and one-fifth of the fuel in the BWR, i.e., about 30 MTU, is replaced with fresh fuel. The fuel consists of uranium dioxide pellets stacked in Zircaloy tubing to form a fuel rod. A fuel assembly is made up of 50 to 200 fuel rods about 4 meters long. A complete assembly weighs 280 to $670 \mathrm{~kg}$, containing approximately $190 \mathrm{~kg}$ of uranium for a BWR and $460 \mathrm{~kg}$ of uranium for a PWR. Thus about 160 assemblies are replaced each year in a BWR and 65 assemblies in a PWR. About 65 percent of the fuel expected to be shipped in 1986 will originate from PWR's with the remain-ing 35 percent from BWR's.

The spent fuel assemblies are highly radioactive at time of discharge from a reactor because of the irradiation and fissioning of the uranium. The spent fuel element contains some plutonium and other heavy elements and large amounts of fission products. As the radioactive atoms decay, they produce radiation and decay heat. The amount of radioactivity remaining in the fuel varies as the function of the length of time after discharge from the reactor. After discharge from the reactor, the fuel assemblies are typically stored in a water-filled basin at the reactor for 6 months or more before bing loaded into a sack for transport to a nuclear fuel reprocessing plant.

Shipping Casks

Al1 rail shipments of spent fuel are made in heavy lead-or uraniumshielded and steel encased casks weighing from 70 to 110 MT (77-121 tons). These containers must meet DOT and $\operatorname{INRC}(1,2)$ regulatory requirements for fissle material packages and for large quantity packages. They are known as Type B packages.

Two casks that have been licensed and fabricated for rail transportation of LWR fuel assemblies are expected to be used extensively in the future. (14) 
They include:

- IF-300 -- A 144,000 1b (65 MT) cask with a capacity of 7 PWR or 18 BWR assemblies (General Electric).

- NLI 10/24 -- A 200,000 1b (90 MT) cask with a capacity of 10 PWR or 24 BWR assemblies (NL Industries).

These were used as reference casks in the study, with the NLI 10/24 used in all shipments from reactors with railroads and the IF-300 for shipments from reactors without rail sidings. The IF- 300 cask was also used in cask capacity sensitivity studies.

In addition to these casks, General Electric has developed a design for a larger rail cask:

- IF-400 -- A 220,000 1b (100 MT) cask with a capacity of 15 PWR and 32 BWR assemblies.

This cask was used in sensitivity studies of effects of cask capacity on shipping costs.

Radiation shielding in spent fuel casks is provided by thick lead or uranium walls encased in steel, which attenuate gamma radiation from the fission products. Hydrogenous material such as water is used to absorb the neutron radiation. The spent fuel casks must also be able to dissipate large amounts of heat, up to $100 \mathrm{~kW}$, produced by radioactive decay. Water or a pressurized gas are usually used in the central cavity to transfer the decay heat from the fuel elements to the body of the cask. The heat is usuaily dissipated to the air through fins on the surface of the cask by natural processes. For some casks, air is forced over the fins by blowers to increase the cooling. The design of these casks assures adequate cooling by natural processes in air even if there is a loss of forced cooling.

\section{Transport Equipment}

The rail equipment used in the shipment of spent nuclear fuel is specially designed railroad flatcars that are used to carry the spent fuel casks. Two rail cars were considered as references for the transport of 
spent fuel: the GE four-axle flatcar and the NLI six-axle flatcar. The characteristics of these cars and their loads are as follows:

\begin{tabular}{|c|c|c|c|c|}
\hline & $\begin{array}{c}\text { Tare Weight } \\
\text { 1b (MT) } \\
\end{array}$ & $\begin{array}{l}\text { Container and } \\
\text { Load Weight } \\
\text { 1b (MT) }\end{array}$ & $\begin{array}{l}\text { Load } \\
1 \mathrm{~b}(\mathrm{MT})\end{array}$ & $\begin{array}{c}\text { Total Weight } \\
\text { 1b (MT) }\end{array}$ \\
\hline $\operatorname{ar}(I F-300)$ & $75,500 \quad(34)$ & $182,000(83)$ & $7,150(3.25)$ & $257,500(117)$ \\
\hline ir & $130,000 \quad(59)$ & $218,870(100)$ & $9,965(4.52)$ & $349,500(159)$ \\
\hline
\end{tabular}

While the rail casks and cars used in shipment of spent fuel represent heavy equipment, they are not unusually heavy or unique. Most new chlorine tank cars going into service have a capacity of 14,000 gallons, or 180,000 1b (82 MT), and a total weight in excess of 240,000 1b (110 MT). Over 10,000 shipments of chlorine are made in these cars each year. Some hopper cars have a gross weight of 263,000 1b (120 MT). These cars are used routinely in conventional freight service. It should also be noted that locomotive units range in gross weight up to 500,000 1b (240 MT).

Accident-Resistance of Spent Fuel Casks

Containers used for shipment of spent fuel must meet DOT and NRC regulations that specify certain accident damage tests. These tests include a sequence of the following: $(2)$

- a free fall from a height of $30 \mathrm{ft}(9 \mathrm{~m})$ onto a unyielding surface with the package landing in the orientation which does the most damage (impact test)

- a free fall from a height of $40 \mathrm{in}$. $(102 \mathrm{~cm})$ onto a $6-i \mathrm{n}$. $(15 \mathrm{~cm})$ diameter solid steel cylinder with the package in the most critical orientation (puncture test)

- heat input from exposure for 30 minutes to a fire having a temperature of $1475 \mathrm{~F}(800 \mathrm{C})$ (thermal test)

- immersion in water to a depth of $3 \mathrm{ft}(0.9 \mathrm{~m})$ for 8 hours (immersion test). 
These tests provide a means for producing the same general type and degree of damage that a cask may be reasonably expected to sustain in a severe transportation accident. Any container shown to meet these standards is called a Type B package and can be expected to withstand extremely severe accidents without release of any of its contents or significant loss of shielding. It should be noted that shipment of spent fuel represents a hazard only if the shipping cask is breached and a significant amount of its contents is released. 


\section{SAFETY ANALYSIS OF CONVENTIONAL FREIGHT TRAINS}

The direct method of determining the potential effect of the proposed special train operating practices on the safety of spent fuel shipments would be to compare special train accident data with conventional freight train accident data. However, no data of statistical significance was available. In the absence of adequate special train data, an estimate of the impact of special trains was made by examining the effect of the proposed special train operating practices using applicable conventional freight train accident data. For example, an estimate of the effect of the $35 \mathrm{mph}$ speed restriction on the probability of freight train accidents was made by determining the fractions of conventional freight train accidents which occur at speeds greater than and less than $35 \mathrm{mph}$. The resulting probabilities were combined with projected spent fuel shipping rates for 1986 to yield estimated accident frequencies for special trains carrying spent fuel.

Freight train accident data for Class I line-haul railroads were analyzed to determine the potential effect of proposed special train restrictions on the frequency and severity of train accidents. The accident data are on computer tapes furnished by the Office of Safety of the Federal Railroad Administration (FRA). The tapes summarize accident information from train accident T-sheets ${ }^{(a)}$ for the years 1972-74. ${ }^{(15)}$ Accident information available on the tapes includes:

- identification of railroad involved

- date of accident (month)

- location of accident (state)

- kind of train

- length of train

- speed of train

- accident class and subclass

- accident cause

- involvement of hazardous material

(a) Rail accident reports (Form T) maintained by Federal Railroad Administration. 
- defective equipment or track, if any

- dollar damage to railroad equipment

- dollar damage to track or roadbed

Proposed operating restrictions which were evaluated by analyzing the accident data on the FRA accident tapes included:

- the $35 \mathrm{mph}$ speed restriction

- the passing restriction

- the no-other-freight restriction

The available statistics were analyzed to determine the potential effect of these operating restrictions on both the overall frequency and the severity of freight train accidents.

\section{EXPERIENCE WITH SPECIAL TRAINS}

The Special Freight Train Service Tariffs define a special train to mean "a train that is operated on an expedited schedule at a charge in addition to the applicable class or commodity rates." ${ }^{(16)}$ Special train service for the shipment of spent fuel is defined in terms of the above statement and the recommended operating practices as suggested to the member railroads by the AAR (see Introduction). The railroads normally furnish special train service upon request and at their convenience. Factors that motivate requests by shippers for such service are speed of delivery and concern for possible damage to fragile and expensive cargo in normal shipping.

This study is based on freight train accident data for the years 1972year moving an average distance of 250 miles. These trains were involved in an average of 5700 reportable accidents per year which translates into approximately one railroad accident for every 350 trains. Available information on special trains shows a ratio of special train service requests to conventional freight service of about $1: 4000 ;{ }^{(17)}$ that is, about 500 special trains per year. Thus, if the special train accident rate is assumed to be 
equal to that of conventional trains, there is a likelihood of less than one special train accident per year. However, more than 65 percent of all freight train accidents are classified as switching yard, low damage accidents. Elimination of such accidents suggests one special train accident every two years. No specific instance of special train accidents was identified. With the low frequency of special train service, this is not an unexpected result.

Information on spent fuel transport by the U.S. Government shows that shipments have been made both in regular freight service with special handling and by special trains. (a) All shipments in regular train service were subjected, by request, to special handling that included no humping, placement of cars at prescribed positions in the train, and a $35 \mathrm{mph}$ speed restriction. Records for 157 shipments for over 700,000 miles (round trip) show no accidents or damage to the shipments. This, again, is not an unexpected result from statistical considerations of train accident data. After 1976 al1 government shipments have been made in spent fuel special trains at the request of the railroads. Information on the number of shipments made in special trains was not available.

\section{TRAIN ACCIDENT STATISTICS}

The definition of a freight train accident, as used in this study, is in accordance with that given in 49 CFR 225. (18) It includes a11 occurrences associated with the operation or movement of trains, locomotives, or cars that result in damage to railroad equipment, track or roadbed in excess of $\$ 750$. (b)

Train accidents are classified as collision, derailment, and other train accidents. (19) Collision accidents are subclassed by the type of collision (rear-end, head-on, etc.), and derailments are subclassed by the

(a) This information was communicated in a letter from C. J. Burkhart, Division of Environmental Control Technology, ERDA.

(b) In 1975 the minimum dollar damage value for a reportable train accident was increased from $\$ 750$ to $\$ 1750$. However, the accident data on which the present study is based are for the years 1972-1974. 
cause of the derailment. Grade crossing accidents that result in at least $\$ 750$ damage to railroad property are classified as other train accidents unless a derailment occurs, in which case the grade crossing accident is classified as a derailment accident.

Basic freight train accident data for the years 1972-1974 are presented in Tables 2 and 3. Table 2 provides information about freight train accident rates. Table 3 provides information about the number of freight train accidents by class of accident. For the years 1972-1974, the freight train accident rate on $\mathrm{Class} I \mathrm{l}$ ine-haul railroads was:

$$
R=1.2 \times 10^{-5} \text { train accident per train mile. }
$$

TABLE 2. Freight Train Accident Rates for 1972-1974, Class I Line-Haul Railroads

\begin{tabular}{|c|c|c|c|}
\hline Year & $\begin{array}{l}\text { Freight Train } \\
\text { Miles(a) } \\
\end{array}$ & $\begin{array}{l}\text { Number of } \\
\text { Freight Train } \\
\text { Accidents (b) } \\
\end{array}$ & $\begin{array}{l}\text { Accidents per } \\
\text { Million Freight } \\
\text { Train Miles } \\
\end{array}$ \\
\hline 1972 & $451,032,000$ & 4,673 & 10.4 \\
\hline 1973 & $469,122,000$ & 6,031 & 12.9 \\
\hline 1974 & $469,728,000$ & 6,449 & 13.7 \\
\hline $\begin{array}{c}\text { Cumulative } \\
1972-74\end{array}$ & $1,389,882,000$ & 17,153 & 12.3 \\
\hline
\end{tabular}

(a) Freight train miles were obtained from Reference 20.

(b) The number of freight train accidents were obtained from the train accident tapes. 
TABLE 3. Number of Freight Train Accidents by Year and by Class of Accident, Class I Line-Haul Railroads Only

\begin{tabular}{|c|c|c|c|c|c|}
\hline \multirow[b]{2}{*}{ Classification } & \multirow[b]{2}{*}{1972} & \multirow[b]{2}{*}{1973} & \multirow[b]{2}{*}{1974} & \multicolumn{2}{|c|}{ Tota 1} \\
\hline & & & & Number & Percent \\
\hline Collision & 456 & 534 & 446 & 1,436 & 8.4 \\
\hline Derailment & 3,760 & 5,050 & 5.571 & 14,381 & 83.8 \\
\hline Other Train Accidents & 457 & 447 & 432 & 1,336 & 7.8 \\
\hline Totals & 4,673 & 6,031 & 6,449 & 17,153 & 100.0 \\
\hline
\end{tabular}

Of these accidents, 8.4 percent were classified as collision accidents, 83.8 percent as derailment accidents, and 7.8 percent as other train accidents.

Reference 13 contains an analysis of the environments that an individual railcar is exposed to when any part of a train is involved in an accident. For collisions, all cars are involved but the magnitudes of the damage producing forces are not identical. For derailments, the data indicate that the average number of cars involved increases with velocity at time of derailment. It was estimated that 10 cars are derailed at $30 \mathrm{mph}$ and 25 at 60 mph. $(13,21,22)$ It was also estimated that 10 cars are involved in side or raking collisions. (13) When these data are combined, the average number of cars involved in an accident is about 10 cars per 66-car train. Thus the railcar accident rate per railcar mile was estimated to be:

$$
R_{C}=1.8 \times 10^{-6} \text { railcar accident per railcar mile. }
$$

Additional accident data used in this study, including data on accident frequency as a function of train speed, accident subclass, and dollar damage, are listed in Appendix B.

\section{DEFINITION OF ACCIDENT SEVERITY}

The most direct measure of accident severity is in terms of the physical forces produced in the accident. However, measurements of accident forces are not routinely available. The parameter chosen to measure accident 
severity for this study was total dollar damage to railroad equipment per accident. Property damage is assumed to be a monotonic function of the magnitude of the physical forces generated by an accident. Thus dollar damage becomes a measure of accident severity. It is recognized that the relationship between dollar damage and accident severity is not necessarily linear and the functional relationship is not well-defined.

Several factors limit the usefulness of dollar damage information as a measure of accident severity. At present there are no industry-wide criteria for determining dollar damage. Different railroad companies may produce different damage estimates for identical accidents, partly because there is no established procedure for depreciating equipment which is damaged after several years of service. An additional factor limiting the usefulness of total dollar damage figures in assessing accident severity is the variation in the number of freight cars involved in an accident. The average number of freight cars involved in an accident is a function of train speed and increases in an approximately linear fashion as the speed increases. $(13,21,22)$

Nevertheless, dollar damage per accident appeared to be the best available indicator of severity. Average dollar damage per car could be used as an indicator of accident severity in 1ieu of dollar damage per accident. Before 1975, however, railroads were not required to report the number of cars involved in an accident and this information is not contained on the FRA accident tapes that were available for use in the study.

Several levels of accident severity, as defined by dollar damage to railroad equipment, were selected for this study: $\$ 750$ (definition of a reportable accident), $\$ 75,000, \$ 150,000$, and $\$ 250,000$ damage to railroad equipment. The last three levels include approximately 7 percent, 3 percent and 1 percent of all railroad freight train accidents. There was no attempt to relate the values selected to severity of accidents that may breach a cask; this is beyond the scope of this study. It should be noted that the results from the analytical, scale-model, and preliminary ful1-scale studies $(5-11)$ indicate that spent fuel casks will not suffer significant damage nor release any of their contents in most accident environments typical of those found in the transportation industry. It is most likely that only accidents 
with severities significantly in excess of $\$ 250,000$ damage level will lead to any kind of threat to cask containment integrity.

\section{EFFECT OF SPECIAL TRAIN RESTRICTIONS}

This analysis sought to determine the effects on the transportation accident environment of the special train restrictions proposed by the AAR. The specific issues analyzed were:

- Speed Restriction - Spent fuel special trains cannot move faster than $35 \mathrm{mph}$.

- Passing Restriction - When trains are involved in passing situations, one train must stop while the other passes at a speed not to exceed 35 $\mathrm{mph}$.

- No-0ther-Freight Restriction - Trains carrying spent fuel can carry no other freight.

The effect of the speed restriction on accident frequency and severity was investigated by analyzing data on the frequencies of train accidents as a function of train speed and dollar damage to railroad equipment. The effect of the passing restriction on accident frequency and severity was investigated by analyzing side or raking accident data. The effect of the no-other-freight restriction was investigated by analyzing data on rail transportation accidents resulting in tank car and locomotive fires.

\section{Effect of Speed Restriction}

Three approaches were used to evaluate the effect of the proposed speed restriction for spent fuel special trains: data were examined on (1) the number of freight train accidents as a function of train speed for 19721974; (2) the frequency of severe (high dollar damage) accidents; and (3) the frequency and severity of freight train collision accidents.

\section{Accident Probabilities as a Function of Speed}

The effect of speed restriction was determined by examining the number of freight train accidents on Class I line-haul railroads as a function of train speed for the years 1972-1974 (see Appendix B). Table B-1 of Appendix B 
provides data for collision accidents; Table B-2 provides data for derailment accidents; and Table B-3 provides data for other train accidents. A11 data are from the FRA accident tapes. The composite accident rate (see Table 2) is $1.2 \times 10^{-5}$ accidents per train mile. A plot of accident frequency versus train speed for all reportable Class I line-haul accidents is shown in Figure 1.

Probabilities of accidents occurring at speeds above and below $35 \mathrm{mph}$ were estimated from the data to be as follows:

$\operatorname{Pr}$ \{accident at speeds below $35 \mathrm{mph} \mid$ train accident $\}=0.809^{(\mathrm{a})}$

$\operatorname{Pr}$ \{accident at speeds above $35 \mathrm{mph} \mid$ train accident $\}=0.191$

The above results suggest that the maximum theoretical reduction in accident probability, due to the speed restriction, is 0.19 . The actual reduction is undoubtedly smaller than this since accidents which occurred at train speeds greater than $35 \mathrm{mph}$ would not have a zero probability of occurrence, as assumed here, if the train speed had been less than $35 \mathrm{mph}$.

Additional insight into the data is gained by relating the number of accidents that occur at a given speed to the total freight train miles traveled at that speed. Unfortunately, the distribution of freight train speed as a function of track mileage is not available. However, a weighted estimate was made, for a representative route, of the length of track on which a freight train would travel at a speed not greater than $35 \mathrm{mph}$ as compared to the total length of track. Using this approach, it was estimated that approximately two-thirds of all freight train miles are traveled at speeds less than $35 \mathrm{mph}$. This estimate was confirmed by examining the speed distribution of derailment accidents caused by factors (i.e., defects or failures of couplers and defects or failures of locomotive and cars) that would be expected to be only weakly coupled to train speed.

(a) Read "The conditional probability that an accident has occurred at speeds below $35 \mathrm{mph}$, given that a train accident has occurred, is 0.809 ." This represents the fraction of all train accidents that occur at speeds below $35 \mathrm{mph}$. 


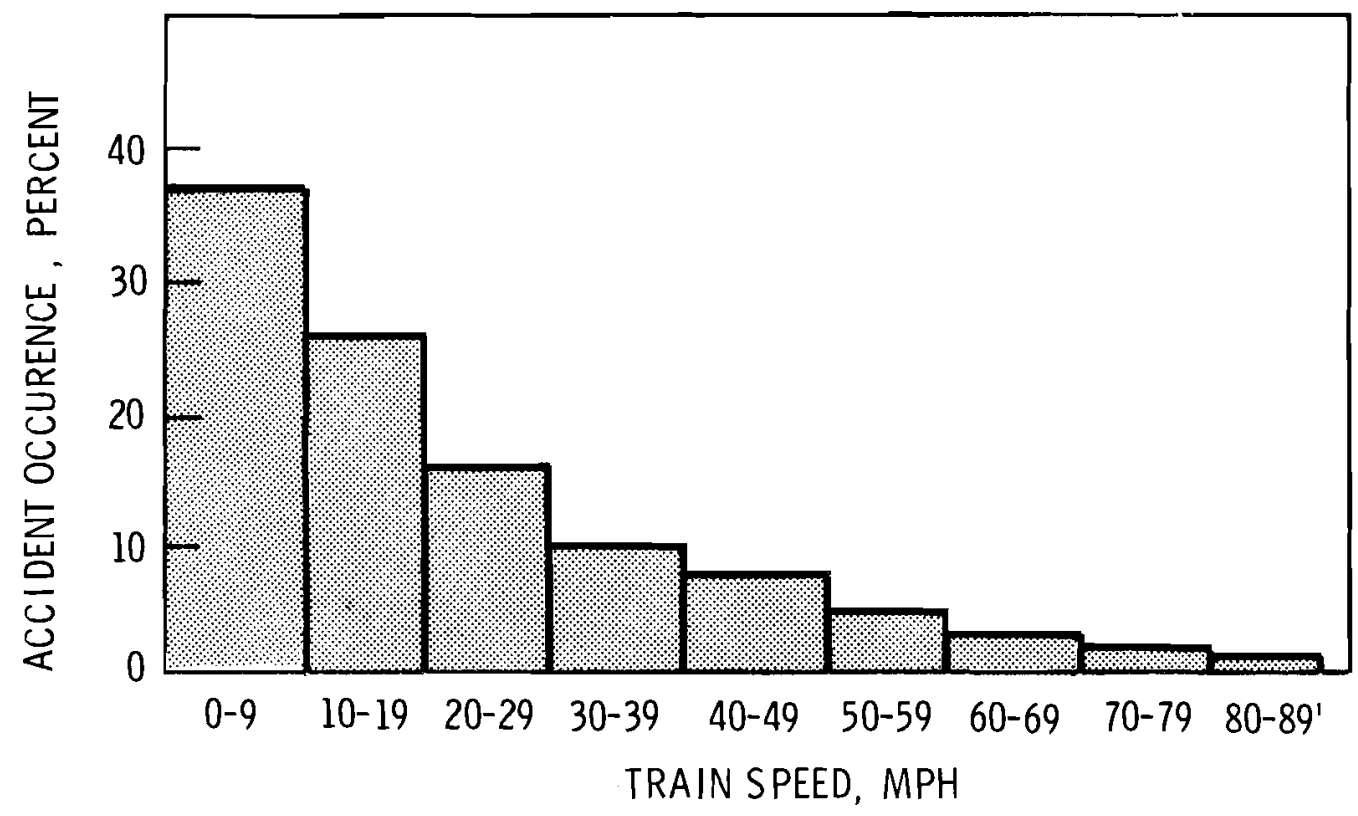

FIGURE 1. Accident Frequency Plotted as a Function of Train Speed for 1972-1974 (17,153 Accidents)

Factoring the mileage distributions into accident frequencies yielded the following accident rates:

$$
\begin{aligned}
& \text { Rate for al1 accidents }=12.3 \times 10^{-6} \text { accidents per train mile } \\
& \text { Rate for accidents at } \\
& \text { speeds below } 35 \mathrm{mph}=14.9 \times 10^{-6} \text { accidents per train mile } \\
& \text { Rate for accidents at } \\
& \text { speeds above } 35 \mathrm{mph}=7.1 \times 10^{-6} \text { accidents per train mile. }
\end{aligned}
$$

Thus the accident rate associated with train speeds less than $35 \mathrm{mph}$ is approximately double the accident rate associated with train speeds greater than $35 \mathrm{mph}$. This is not meant to suggest that it is safer to travel at high speeds but rather to suggest that accident-inducing factors are greatest in those portions of the railroad system that have speed limits of $35 \mathrm{mph}$ or lower. Speed limits are normally associated with rail yards, bad track, 
curves, bridges, grade crossings, populated areas and other physical constraints. Thus, it appears that speed restrictions necessary for safety already exist where necessary.

\section{Accident Probabilities as a Function of Speed and Severity}

To evaluate the effect of a $35 \mathrm{mph}$ speed limit on accident severity, the frequency of high dollar damage accidents was examined. Table B-4 of Appendix $B$ shows numbers of freight train accidents with dollar damage to railroad property exceeding $\$ 75,000, \$ 150,000$ and $\$ 250,000$ per accident. The speed distributions for these accidents are shown graphically in Figures 2, 3 , and 4. Dollar damage levels were chosen arbitrarility with the lowest $(\$ 75,000)$ being greater by a factor of 100 than the reporting threshold for a train accident. During the period 1972-1974, 7 percent of all freight train accidents resulted in dollar damage in excess of $\$ 75,000 ; 3$ percent of all freight train accidents resulted in dollar damage in excess of $\$ 150,000$; and about 1 percent of all freight train accidents resulted in dollar damage in excess of $\$ 250,000$.

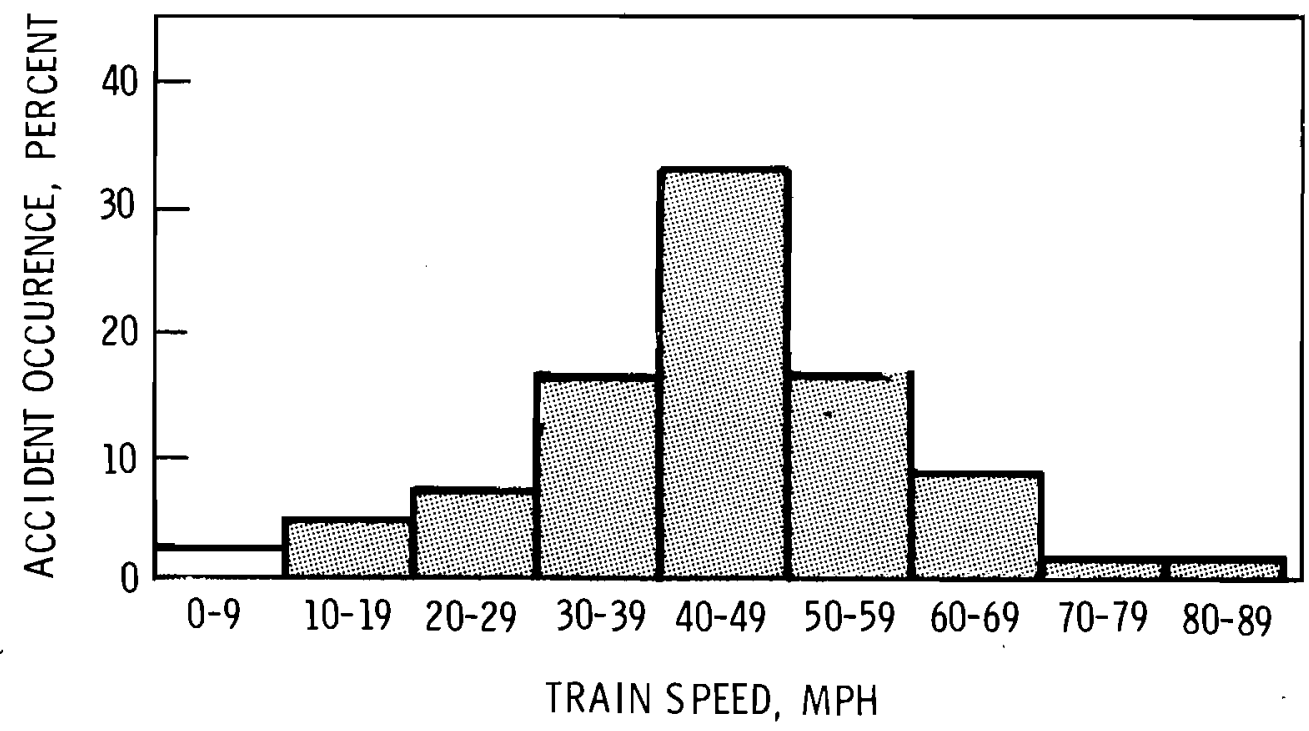

FIGURE 2. Accident Distribution Versus Train Speed for Freight Train Accidents with Damage Exceeding $\$ 75,000$ (Class I Line-Haul Railroads, 1972-1974) 

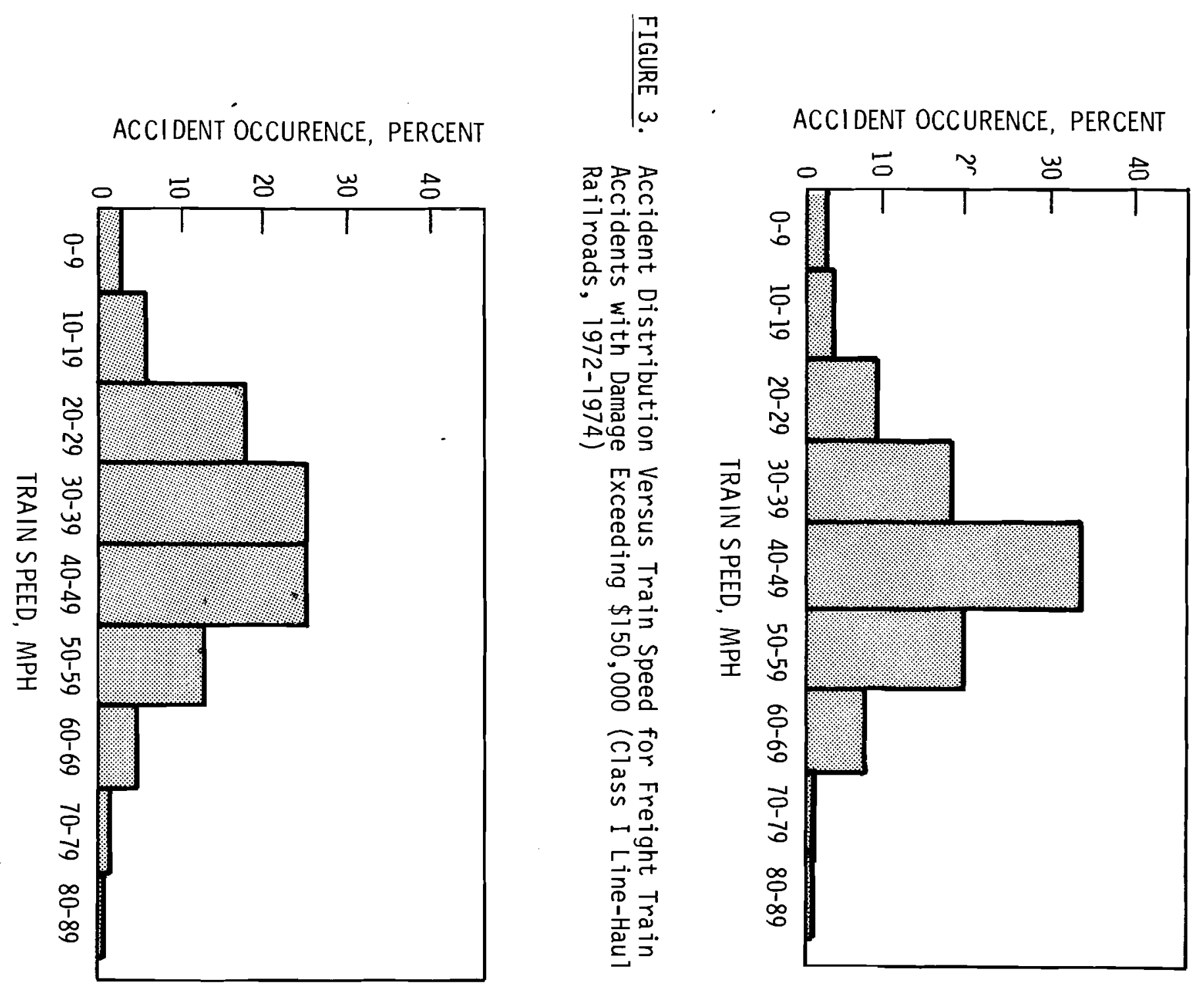
The probabilities of accidents occuring at speeds above and below $35 \mathrm{mph}$ with dollar damage per accident greater than $\$ 75,000$ were estimated from the data to be as follows:

$\operatorname{Pr}\{$ accident with more than $\$ 75,000$ damage $\mid$ train accident $\}=0.069$

$\operatorname{Pr}$ accident at less than $35 \mathrm{mph}$ and more than $\$ 75,000$ damage | train accident\}

$\operatorname{Pr}$ accident at more than $35 \mathrm{mph}$ and more than $\$ 75,000$ damage | train accident\}

The probabilities of accidents occurring at speeds above and below 35 mph with dollar damage per accident greater than $\$ 150,000$ were estimated from the data to be as follows:

$\operatorname{Pr}$ accident with more than $\$ 150,000$ damage | train accident\} $=0.030$

$\operatorname{Pr}$ accident at less than $35 \mathrm{mph}$ and more than $\$ 150,000$ damage | train accident\}

$$
=0.009
$$

$\operatorname{Pr}$ accident more than $35 \mathrm{mph}$ and more than
$\$ 150,000$ damage | train accident\}
$=0.021$.

The probabilities of accidents occurring at speeds above and below $35 \mathrm{mph}$ with dollar damage per accident greater than $\$ 250,000$ were estimated from the data to be as follows:

$\operatorname{Pr}$ accident with more than $\$ 250,000$ damage | train accident

$$
=0.013
$$

$\operatorname{Pr}$ accident at less than $35 \mathrm{mph}$ and more than $\$ 250,000$ damage | train accident $\} \quad=0.003$

$\operatorname{Pr}$ accident at more than $35 \mathrm{mph}$ and more than $\$ 250,000$ damage | train accident $=0.010$.

These probabilities indicate that an accident at a train speed greater than $35 \mathrm{mph}$ is more likely to result in a high dollar damage than is an accident at a train speed less than $35 \mathrm{mph}$. There are two factors that contribute to these results. First, the impact forces are greater in accidents involving trains moving at high speeds than they are in accidents involving trains moving at slow speeds, and thus the potential for severe damage is greater. 
Second, the number of rail cars involved in an accident will, on the average, increase as the train speed increases, and thus the cumulative damage to railroad equipment is higher. It should be noted that severe accidents are not eliminated by the speed restriction, thus indicating that severity is not a function of speed alone.

The absence of a strong dependence of accident severity on train speed is illustrated by the distribution of average dollar damage per car as a function of train speed. Figure 5 shows, for the year 1973, the average dollar damage per car for all freight train accidents for which total dollar damage exceeded $\$ 100,000$. The data are plotted as a function of train speed at the time of an accident. For accidents plotted in Figure 5, the average dollar damage per car ranges from less than $\$ 1000$ to almost $\$ 40,000$. Theoretically, high average impact forces (forces related to large magnitude changes in train speed) would be reflected in high dollar damage to an effected railcar. An increase in average dollar damage per car with increasing train speed might, therefore, be expected from the data. As shown in Figure 5, the average dollar damage per car varies over wide limits and is relatively insensitive to the speed of a train at the time of an accident.

Part of the variation in average dollar damage per car for accidents in a given speed range is probably due to the lack of uniformity in damage estimating techniques used by different railroads. However, the absence of a strong dependence of average car damage upon train speed in the data suggests that the severity of impact upon a railcar might not be directly related to train speed. This may be partly explained by the fact that only the first few cars are subjected to the maximum impact of an accident; subsequent cars are cushioned from severe impact by the preceeding cars. In a derailment accident, the number of cars derailed has been found to depend on train speed at the time of derailment. (13,21,22) However, after the first car derails, succeeding cars derail at successively lower speeds and thus at lower levels of severity. An additional factor which affects car damage is the geographical environment of an accident and the availability of objects which have a potential for doing serious damage to an impacting railcar. 


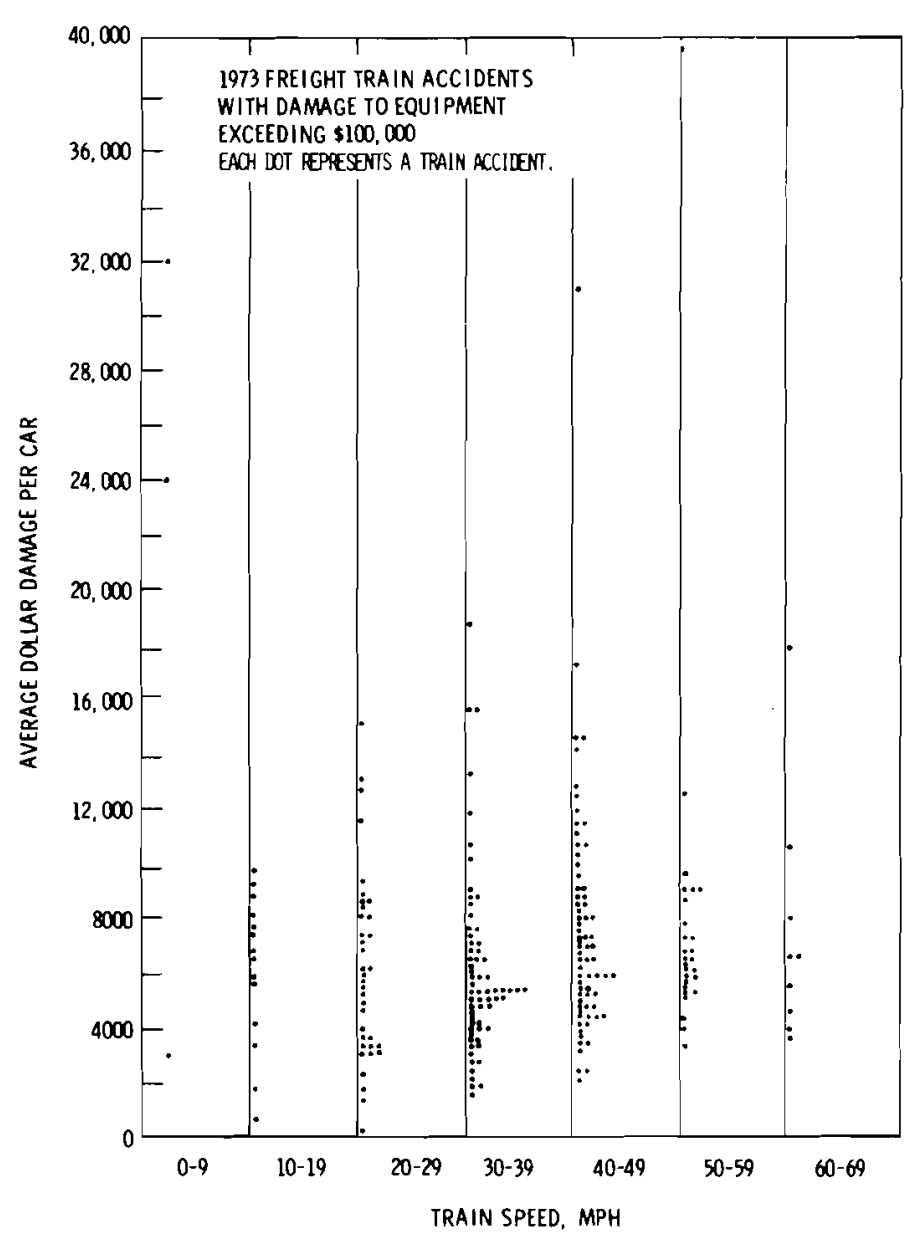

FIGURE 5. Distribution of Dollar Damage per Car as a Function of Train Speed

The effect of the speed restriction may not be as pronounced as indicated by the probabilities. For the accidents defined by $\$ 250,000$ damage, the likelihood of these severe accidents occurring is small, about one percent of all freight train accidents. Furthermore, al though the maximum potential reduction in the probability of these accidents is nearly 70 percent, the actual reduction would be much less. The large potential reduction assumes zero accident rate for those accidents that occurred at speeds above $35 \mathrm{mph}$ when they are replaced by conditions restricting speeds to $35 \mathrm{mph}$. In fact, a significant fraction of accidents is due to employee negligence, obstructions, defects or failures of couplers, defects or 
failures of braking mechanisms, and defects or failures of locomotives and cars. These factors are relatively independent of speed.

The possible importance of the $35 \mathrm{mph}$ speed restriction in reducing the frequency of spent fuel cask involvement in severe (i.e., high dollar damage) accidents may be estimated by combining spent fuel cask mileage information with freight train accident data. For this calculation it is necessary to assume that a spent fuel cask would be carried in regular train service. During the 3-year period for which data are available there were 229 freight train accidents with damage exceeding $\$ 250,000$ (see Table B-4). The total freight car mileage for this period was approximately 92 billion car miles. Assuming an average of 10 cars involved in an accident, the frequency of a freight car being involved in a $\$ 250,000$ accident was approximately $2.5 \times 10^{-8}$ per car mile. In 1986 the total mileage of spent fuel shipments is estimated to be about 500,000 miles. If spent fuel is shipped on regular trains and the same accident frequency is assumed, the expected frequency of involvement of a spent fuel shipment in a $\$ 250,000$ accident would be $1.3 \times 10^{-2}$ accidents per year or about one accident every 80 years. It should be noted that involvement of a spent fuel cask in an accident of this severity does not imply a threat to the cask containment integrity. Expected frequencies for involvement of a spent fuel cask in $\$ 150,000$ and $\$ 75,000$ accidents are one accident every 35 years and one accident every 15 years, respectively, for levels of spent fuel shipments projected for 1986. If the regular train were restricted to a maximum speed of $35 \mathrm{mph}$, assuming maximum effect of the restriction (i.e., zero rate for accidents which had occurred at speeds greater than $35 \mathrm{mph}$ ), the expected frequencies for involvement of a spent fuel cask in $\$ 250,000, \$ 150,000$ and $\$ 75,000$ accidents would be one accident per 320 years, 120 years and 35 years, respectively.

In summary, the maximum potential effect of the speed restriction on spent fuel shipments is a small reduction in overall accident probability. There is a potential reduction in the rates of severe accidents. However, it will take a very severe accident (one which has not been defined) to breach a cask and the frequency of such an accident involving a spent fuel cask car is likely to be low. Shappert et al. (23) estimate the frequency of 
accidents that would cause a large release from a cask of spent fue 1 to be less than $2 \times 10^{-12}$ per vehicle mile. Based on 1986 level of spent fuel shipments, this suggests one such accident per 1,000,000 years. It is also important to note that the speed restriction does not eliminate very severe accidents.

\section{Collision Accident Probabilities}

Data on freight train collision accidents were analyzed to further evaluate the effect of the proposed special train speed restriction. Table B-5 of Appendix B shows the distribution of freight trains involved in collision accidents as a function of accident subclass and train speed for the period 1972-1974. To evaluate the effect of the proposed speed restriction, only those collision accidents classified as rear-end, head-on, and side or raking were considered.

The total number of freight trains involved in rear-end, head-on, and side or raking collisions, for the period 1972-1974, was 271. Of these trains, 20 were traveling in excess of $35 \mathrm{mph}$ at the time of collision. Thus, for collision accidents in these subcategories, the probabilities of a train being involved in an accident while traveling at speeds below and above 35 miph are estimated to be:

$\operatorname{Pr}$ \{accident at speed less than $35 \mathrm{mph} \mid$ collision $=0.926$

$\operatorname{Pr}\{$ accident at speed greater than $35 \mathrm{mph} \mid$ collision $\}=0.074$

These results suggest that the maximum theoretical reduction in the probability of a rear-end, head-on, and side or raking collision, due to the speed restriction, is only about 7 percent.

of the 271 freight trains involved in rear-end, head-on, and side or raking accidents, 51 trains (19 percent) sustained dollar damage to railroad equipment in excess of $\$ 75,000$. Of these 41 trains were traveling at speeds less than $35 \mathrm{mph}$. Corresponding probabilities were estimated to be:

$\operatorname{Pr}$ \{accident with more than $\$ 75,000$ damage | rear-end, head-on, side or raking accident\}

$=0.188$ 
$\operatorname{Pr}$ \{accident at less than $35 \mathrm{mph}$ and more than $\$ 75,000$ damage | rear-end, head-on, side or raking accident?

$\operatorname{Pr}$ accident at more than $35 \mathrm{mph}$ and more than $\$ 75,000$ damage / rear-end, head-on, side or raking accident\}

There were 28 rear-end, head-on, and side or raking accidents with damage exceeding $\$ 150,000$ and 21 such accidents with damage exceeding $\$ 250,000$. The probabilities of such accidents occuring at speeds below and above $35 \mathrm{mph}$ are as follows:

$\operatorname{Pr}$ \{accident with more than $\$ 150,000$ damage | rear-end, head-on, side or raking accident $=0.104$

Pr accident at less than $35 \mathrm{mph}$ and more than $\$ 150,000$ damage | rear-end, head-on, side or raking accident?

$\mathrm{Pr}$ accident at more than $35 \mathrm{mph}$ and more than $\$ 150,000$ damage | rear-end, head-on, side or raking accident

and

$\operatorname{Pr}$ accident with more than $\$ 250,000$ damage | rear-end, head-on, side or raking accident

$\mathrm{Pr}$ \{accident at less than $35 \mathrm{mph}$ and more than $\$ 250,000$ damage | rear-end, head-on, side or raking accident\}

$\operatorname{Pr}$ \{accident at more than $35 \mathrm{mph}$ and more than $\$ 250,000$ damage | rear-end, head-on, side or raking accident\}

For 1986 shipping levels, the frequencies of such accidents for trains carrying spent fuel in conventional freight train service are one incident every 60 years, 110 years and 130 years for $\$ 75,000, \$ 150,000$ and $\$ 250,000$ accidents, respectively. This is based on the assumption that every car in a train collision accident is affected. If a more realistic average of 10 affected cars per accident is used, $(13,21,22)$ the rates become one incident per 400 years, 700 years, and 860 years, respectively. The maximum effect of the passing restriction would be to reduce these incident rates to one 
incident every 490 years, 880 years and 1,000 years for the $\$ 75,000, \$ 150,000$ and $\$ 250,000$ accidents, respectively. The net effect of the speed restriction on the frequency of involvement of a spent fuel cask in collision accidents of various severities appears to be small. As was noted previously, the cask can be expected to maintain its containment integrity in accidents greatly exceeding $\$ 250,000$ in damage.

\section{Effect of Passing Restriction}

The passing restriction recommended by the AAR appears to have less impact on freight train accident rates than the speed restriction discussed in the previous section. The passing restriction will primarily affect only side or raking accidents. Furthermore, the restriction appears to be redundant since on many lines, when two trains meet, one train must be stationary on a side rail. The passing restriction will have a significant effect primarily on freight train traffic on railroad lines with double main track. These comprise approximately 11 percent of the aggregate length of roadway for Class I line-haul railroads. (a)

To establish the maximum impact of the restriction, all side or raking accidents for Class I line-haul railroads for the period 1972-1974 were examined (see Table B-5, Appendix B for a summary of the results). A total of 97 trains was involved in these accidents. The probabilities of a train being involved in a side or raking accident while traveling at speeds above and below $35 \mathrm{mph}$ were found to be:

$$
\begin{array}{ll}
\operatorname{Pr} \text { \{accident at speed less than } 35 \mathrm{mph} \mid & =0.959 \\
\text { side or raking accident }\} & \\
\operatorname{Pr}\left\{\begin{array}{c}
\text { accident at speed greater than } \\
35 \mathrm{mph} \mid \text { side or raking accident }\}
\end{array}\right. & =0.041
\end{array}
$$

Thus, only 4 percent of all side or raking accidents involve a train traveling at a speed above $35 \mathrm{mph}$.

(a) Total second main track mileage was 24,866 miles in a total of 216,530 miles of railroad line. 
The data collected on the accident tapes indicates accident speed in $10 \mathrm{mph}$ blocks. The probability of a train being involved in a side or raking accident while traveling at speeds between 0 and $9 \mathrm{mph}$ was found to be:

$\operatorname{Pr}$ \{accident at speeds between 0 and $9 \mathrm{mph}$ side or raking accident\} $=0.711$

Assuming that the trains involved in side or raking accidents recorded in the $0-9$ mph data block are standing sti11, only about 29 percent of side or raking accidents would be affected by the passing restriction.

The expected frequency of such accidents for spent fuel shipments can be estimated using the level of activity of spent fuel shipments projected for 1986 . The potential reduction in all side or raking accidents involving spent fuel is from one per 60 years to one per 90 years. The frequency of involvement of a spent fuel cask in conventional freight train service in side or raking accidents with $\$ 75,000, \$ 150,000$ and $\$ 250,000$ damage were estimated to be once every 860 years, 3000 years and 6000 years, respectively. This is based on 500,000 miles of spent fuel shipments and an average of 10 rail cars affected by a side or raking accident. Since only about 11 percent of rail lines have second main lines, since side or raking accidents have a low frequency of occurrence, and since 71 percent of the side or raking accidents occur with trains standing still, the impact of the passing restriction appears to be negligible.

An important contributor to the incidence of side or raking accidents is train sway. The amplitude of sway of a car is not a linear function of the train speed but undergoes resonance at intermediate speeds. Resonance occurs at speeds between 10 and $25 \mathrm{mph}$, with the exact speed determined by such factors as mass, wheel base, spring constants and damping associated with each car. $(24,25)$ The passing restriction has a limited effect on this factor since the speed of the moving train is not controlled.

\section{Effect of No-Other-Freight Restriction}

The no-other-freight restriction proposed by the AAR is primarily intended to reduce the frequency of exposure of spent fuel casks to large fires. The 
potential effect of this restriction was investigated using information on the expected duration of freight train fires and data on the frequency of locomotive fires.

The probability per car mile that a spent fuel cask carried in normal train service will be exposed to a fire with a duration equal to or greater than a particular value is shown in Figure 6 . The information presented in the figure was obtained from A. W. Derinis of Sandia Laboratories. A Monte Carlo computer simulation was used to estimate the frequency of occurrence of fires of various durations. All flammable materials present in freight trains were included in the analysis. The probability numbers assume that a spent fuel cask would be exposed to one in ten fires that occur in the train in which the car is carried. This assumption is believed to be conservative since $90 \%$ of all freight train fires involve only a single car and since heat fluxes from the fires drop off rapidly with distance.

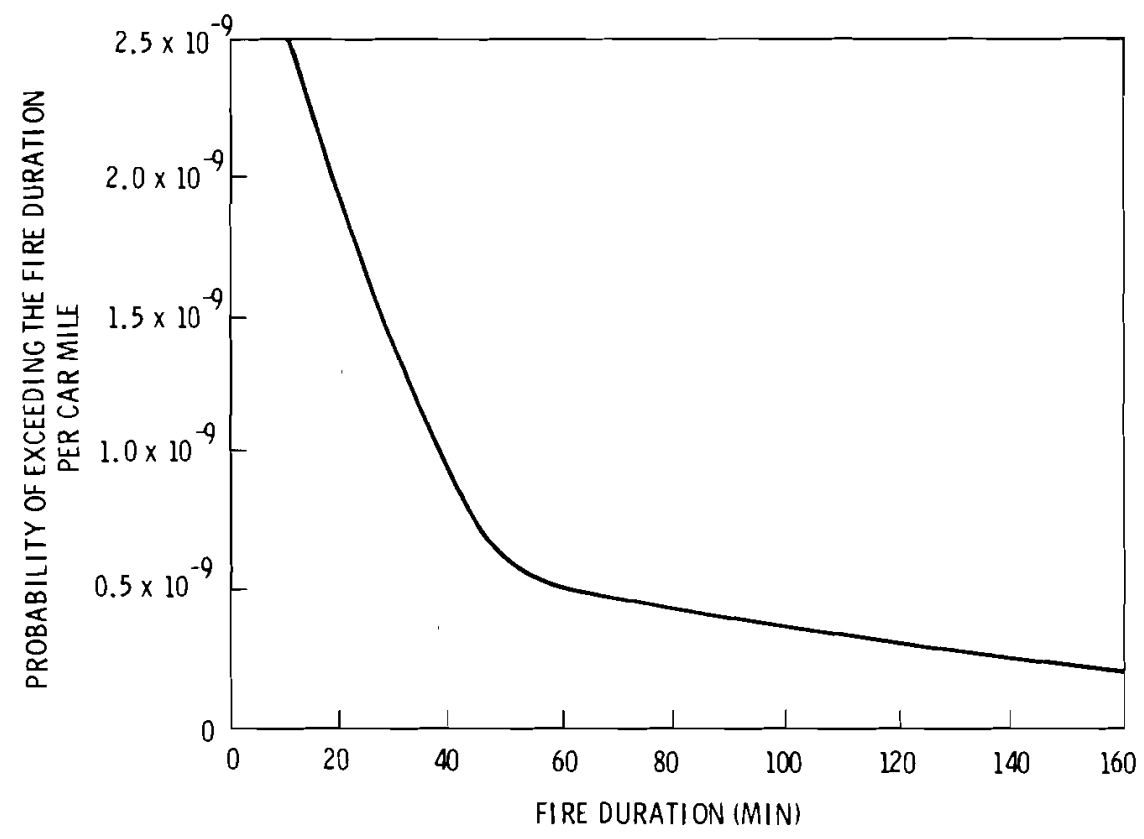

FIGURE 6. Estimated Probability per Car Mile that a Spent Fuel Cask in Normal Train Service will be Involved in a Fire with a Duration Exceeding that Shown 
Figure 6 shows that the probability that a spent fuel cask will be exposed to a fire with a duration of 30 minutes or more is about $1.5 \times 10^{-9} / \mathrm{mile}$. Detailed thermal analysis of the cask is required to determine the duration of fire that would result in release of radioactive material from the cask. Such analysis was beyond the scope of this study. The casks must be shown to be capable of withstanding a $1475^{\circ} \mathrm{F}$ fire for 30 minutes before they are licensed. Although exposure of the casks to longer fires does not necessarily imply a release of radioactive material, the licensing standard does provide a reasonable basis for comparing the fire hazard in regular train service with special train service. Using a total spent fuel shipping distance of 500,000 miles per year, it is estimated that a spent fuel cask carried in regular freight train service would be exposed to a fire exceeding the regulatory qualification test once in 1300 years.

If spent fuel casks were carried in special trains carrying no other freight, many of the potential fire sources present in a regular train would be eliminated. The casks would still be subject to exposure to fires involving the fuel carried in the locomotive. The frequency of exposure to locomotive fires can be estimated from data for regular train accidents. Locomotive fires occur in $26 \%$ of all fires that occur in collision accidents and $14 \%$ of all fires that result from derailments. ${ }^{(27)}$ As indicated in Table 3 (p. 14), derailments account for $83.8 \%$ of all accidents and collisions for $8.4 \%$ of a 11 accidents. These accidents result in fire about $1 \%$ of the time. (a) Combining this information, the probability of a locomotive fire, given that an accident has occurred is $1.4 \times 10^{-3}$.

The overall accident rate for regular train service is 1.2 accidents per 100,000 train miles. The accident rate for special trains can be estimated from the regular train accident information by removing the data on accidents that occur at speeds above $35 \mathrm{mph}$. Data on page 17 indicate that $9 \%$ of all regular train accidents occur at speeds above $35 \mathrm{mph}$. Adjusting the regular train accident rate by this amount results in a special train

(a) This information was furnished by A. W. Dennis of Sandia Laboratories. 
accident rate of $9.7 \times 10^{-6}$ per train mile. For a 500,000 mile shipping distance, a locomotive fire could then be expected to occur on a special train carrying a spent fuel cask about once in 140 years. The size of these fires will vary depending on the amount of fuel carried in the locomotive and the fraction of the fuel that is released in the accident. Information used to derive Figure 6 indicates that about $90 \%$ of locomotive fires last longer than 30 minutes. Since a spacer car is generally used between the locomotive and the spent fuel car, it is expected that the cask would not be exposed to a11 the fires that occur. Assuming, as before, that the cask is exposed to one fire in ten, spent fuel casks carried in special trains are estimated to be exposed to thermal environments that could threaten the cask integrity once in 1600 years for 1986 shipping levels.

In conclusion, the no-other-freight restriction does appear to have some potential for reducing the frequency of exposure of spent fuel casks to major fires, but the exposure rate even in conventional freight train service is still quite low.

\section{Considerations in the Safety of Spent Fuel Shipments}

Spent fuel is transported in massive thick-walled casks designed to retain shielding and containment integrity under Type $B$ accident conditions. Type $B$ damage test criteria include impact, puncture and fire tests which simulate the accident environments likely to be encountered in severe transportation accidents. The protection provided by Type $B$ package requirements has been investigated by intensive analytical studies $(5-7)$ and by small-scale model studies. $(8,9)$ Full-scale testing to confirm the model studies is underway. $(10,11)$ Results of cask test programs indicate that spent fuel casks will withstand very severe accidents.

A spent fuel cask may be regarded as providing double containment for irradiated fuel during transport. The first barrier to an accidental release of radioactivity is provided by the fuel cladding. The second barrier is provided by a combination of inner shell, gamma shield and outer shel1 which constitute the cask body. For a release to occur during transport, radioactive material must first escape to the cask cavity from 
perforated fue 1 rods. The material must then be released from the cask atmosphere as a result of a penetration of cask containment. The cask may be penetrated through one of three paths: failure of pressure relief mechanisms, loss of sealing capability of the closure head or breachment of the cask. Because of the way a cask is constructed, barrier failure from accidental breachment of the cask is considered to be an extremely unlikely event.

If a failure of containment were to occur as the result of a transportation accident, it would probably consist of small penetrations (cracks) in fuel rod cladding and in failure of pressure relief or cask head closure mechanisms which would result in very small openings into the cask. Even a very severe accident would probably release only a small fraction of the radioactivity contained within a cask. The most likely material release would be the loss of cask cavity coolant (usually water or helium). Radioactivity in the cavity coolant would also be released. More severe accidents could result in the rupture of some fuel rods and a release of fission gases from fuel rod void spaces. A high temperature environment severe enough to cause fuel rod perforation from thermal-hydraulic effects would probably result in the release of a small fraction of the cesium contained in these rods.

Although there have been many transportation accidents with Type B packages and about ten of these accidents might be considered severe, no release of radioactivity has resulted. ${ }^{(28)}$ Thus there has apparently been no accident that subjected a Type B container to the most severe accident conditions that it is able to withstand. To establish the likelihood of a release of radioactive material in a transportation accident and the impact of spent fuel special trains on transportation safety, it is important to determine quantitatively the levels of forces that could cause cask breach and compare these forces with the kinds and magnitudes of forces encountered in railroad accidents. 


\section{ECONOMIC IMPACT OF SPECIAL TRAIN REQUIREMENTS ON SPENT NUCLEAR FUEL SHIPMENTS}

Analysis of the economic impact of the special train requirements is a complex problem because it involves the interaction of a number of variables with considerable uncertainty. These items include (1) freight tariff, (2) special train charges, (3) cask use charges, (4) travel time from reactor to reprocessing plant, (5) terminal time for the cask at both the reactor and reprocessing plant, (6) frequency of cask car pickup and delivery by the railroad, (7) cask utilization and (8) cask capacity.

Economic impact of the special train requirements was examined primarily from the viewpoint of cost to the shipper. The basic cost factors were freight tariffs, special train charges, and cask use charges. The variability of these parameters necessitated a sensitivity study based on variations in these parameters. The sensitivity study also included items (4) through (8) above.

Previous studies have evaluated the economic impact of spent fuel special trains by considering only railroad revenues. The basic cost factors in these studies have been freight tariffs and special train charges. An analysis of the economic impact of special trains based on railroad revenues using the cost data developed for this study is presented at the end of the chapter. The previous work using this method is extended by evaluating the change in railroad revenues for spent fuel special trains with one to five cask cars per train.

To minimize the uncertainties of analysis, an accurate and detailed railroad network was used. Freight tariffs, travel times, and special train charges for a selected series of potential shipments to the proposed reprocessing plants at Barnwe11, SC, and Oak Ridge, TN, were developed. These routes and the related data are shown in Appendix $A$.

Three casks for spent fuel transport were considered in the analysis-the GE IF-300, the NLI 10/24 cask and the GE IF-400. Definitions of the reference cask parameters are shown in Table 4. Use charge estimates for the 
IF-300 and NLI 10/24 casks are based on discussions with NLI and GE personnel but do not represent contractual agreements. The GE IF-400 is in a design status only, and preliminary costs and terminal times associated with using this cask had to be estimated for the study. Where multiple casks are carried by the special train, the terminal time was increased since each cask must wait for the other casks for loading and unloading.

\section{TABLE 4. Reference Cask Parameters}

Casks Considered

NLI 10/24 - GE IF-300 - GE IF-400

Capacity, MT

4.52

3.25

6.75

Use Charge, \$/day

$\begin{array}{llll}\text { Reference } & 2,500 & 2,750 & 3,000 \\ \text { Upper Estimate } & 3,000 & 3,000 & 3,500\end{array}$

Total Terminal

Time, days

Regular Train

5

4

6

Special Train

\begin{tabular}{|c|c|c|c|c|c|c|}
\hline No. of Casks & One-Way & Both Ways & One-Way & Both Ways & One-Way & Both Ways \\
\hline 1 & 5 & 5 & 4 & 4 & 6 & 6 \\
\hline 2 & 7.5 & 10 & 6 & 8 & 9 & 12 \\
\hline 3 & 10 & 15 & 8 & 12 & 12 & 18 \\
\hline 4 & 12.5 & 20 & 10 & 16 & 15 & 24 \\
\hline
\end{tabular}

Shipping costs were analyzed by the TRAINS computer code (Appendix C), which was developed at PNL for this study. This code determines the lowest cost configuration of casks carried per trip for each reactor, calculates the freight charges, cask use charges and special train charges, and sums them for each reprocessor. IMPACT OF SPECIAL TRAIN RESTRICTIONS ON SHIPPER'S TRANSPORTATION COSTS

Table 5 shows the cost summary for reference rail shipments to three proposed reprocessing locations in 1986. Most of the shipments were assumed 
to be to the AGNS plant in Barnwe11, SC, with a proposed EXXON plant at Oak Ridge, TN handling most of the remainder.

TABLE 5. Rail Shipping Cost Summary for 1986 Reference Case

\begin{tabular}{|c|c|c|c|c|c|c|}
\hline \multirow{3}{*}{$\begin{array}{l}\text { Number of Reactors } \\
\text { Shipping Spent } \\
\text { Fuel }\end{array}$} & \multicolumn{6}{|c|}{ Reprocessing Sites } \\
\hline & \multicolumn{3}{|c|}{ Barnwe11, SC } & \multicolumn{3}{|c|}{ Dak Ridge, TN } \\
\hline & & 62 & & & 31 & \\
\hline $\begin{array}{l}\text { Total Spent Fuel } \\
\text { Shipped, kg }\end{array}$ & & $1,477,000$ & & & 812,000 & \\
\hline Train Category & Regular & $\begin{array}{l}\text { Special } \\
\text { One-Way } \\
\end{array}$ & $\begin{array}{c}\text { Special } \\
\text { Both Ways } \\
\end{array}$ & Regular & $\begin{array}{l}\text { Special } \\
\text { One-Way } \\
\end{array}$ & $\begin{array}{c}\text { Special } \\
\text { Both Ways } \\
\end{array}$ \\
\hline $\begin{array}{l}\text { Total Shipment } \\
\text { Costs Millions } \\
1975 \text { dollars }\end{array}$ & 22.9 & 29.2 & 34.7 & 15.1 & 15.7 & 18.3 \\
\hline Unit Costs $\$ / \mathrm{kg}$ & $15.50^{(a)}$ & $19.80^{(a)}$ & $23.50^{(\mathrm{a})}$ & 15.00 & 19.30 & 22.60 \\
\hline $\begin{array}{l}\text { \% Over Regular } \\
\text { Train }\end{array}$ & -- & $28 \%$ & $52 \%$ & -- & $29 \%$ & $50 \%$ \\
\hline $\begin{array}{l}\text { Number of Casks } \\
\text { Required per year }\end{array}$ & $19^{(a)}$ & $22^{(\mathrm{a})}$ & $24^{(a)}$ & 11 & 13 & 14 \\
\hline
\end{tabular}

\footnotetext{
(a) Since some reactors do not have rail heads, 3 of the casks are IF- $-300,3.25$ MT intermodal casks. Unit costs are weighted averages of costs using NFS 10/24 4.52 MT casks and the 3 IF- 300 casks.
}

\section{Reference Case}

The reference case used the estimates of parameters shown in Table A-2 of Appendix A. The reference case assumed equal transit times for regular and special trains. The reference case also assumed that the bimodal, 3.25-MT truck-train cask would be used for 1986 shipments from Athens, AL; Seneca, SC; Florida City, FL and Ft. Pierce, FL because of the lack of railheads at the reactors. A11 other reactors were assumed to use 4.52-MT rail casks.

Figure 7 shows the average unit costs for shipments to each reprocessor as well as the freight, special train, and cask use cost components. Units 
of cost are given as dollars per kilogram $(\$ / \mathrm{kg})$ of uranium. Table 6 details the cost components and shows that average freight charges are dependent on origin and destination points and thus are invariant for each reprocessor. Since multiple cask shipments are more economic and thus used, special trains have higher cask use charges because of increased terminal times caused by casks waiting for other casks to be loaded or unloaded. However, this higher cost is offset by reduced special train charges per cask in multiple car shipments.

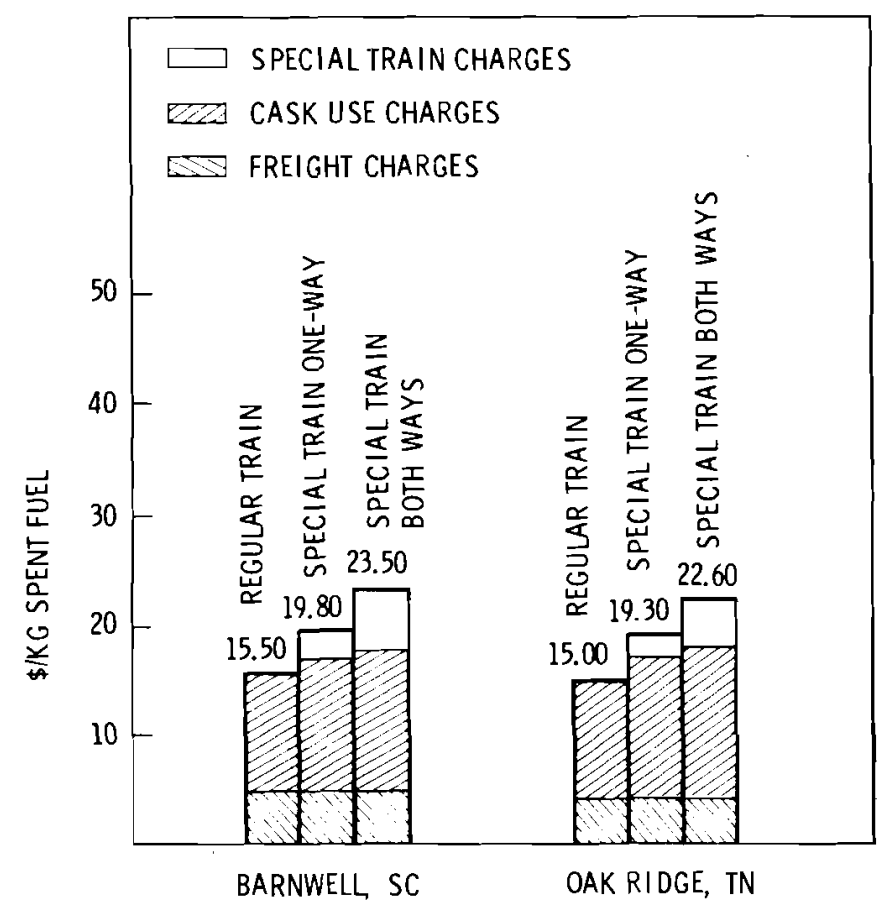

FIGURE 7. Average Unit Cost of Spent Fuel Rail Shipments to Reprocessors in 1986

The cost results using the reference case parameters show that special train requirements for traveling in both the loaded and unloaded direction increase the total average unit costs from $\$ 15.50 / \mathrm{kg}$ to $\$ 23.50 / \mathrm{kg}$ and $\$ 15.00 / \mathrm{kg}$ to $\$ 22.60 / \mathrm{kg}$ from Barnwell and Oak Ridge, respectively. If special trains are required only for the loaded shipment from reactor to reprocessor, unit 
TABLE 6. Average Costs for Spent Fuel Rail Shipments to Reprocessing Plants in 1986

\begin{tabular}{|c|c|c|c|c|c|}
\hline $\begin{array}{l}\text { Reprocessing } \\
\text { Plant }\end{array}$ & Shipping Method & $\begin{array}{c}\text { Freight } \\
\text { Charges, } \\
\$ / \mathrm{kgU} \\
\end{array}$ & $\begin{array}{c}\text { Special Train } \\
\text { Charges, } \\
\$ / \mathrm{kgU} \\
\end{array}$ & $\begin{array}{l}\text { Cask Use } \\
\text { Charges, } \\
\$ / \mathrm{kgU} \\
\end{array}$ & $\begin{array}{c}\text { Total Unit } \\
\text { Cost, } \\
\$ / \mathrm{kgU} \\
\end{array}$ \\
\hline \multirow[t]{3}{*}{ Barnwel1, SC } & Special Train 2-way & 5.00 & 5.50 & 13.00 & 23.50 \\
\hline & Special Train 1-way & 5.00 & 3.00 & 12.00 & 20.00 \\
\hline & Regular Train & 5.00 & -- & 10.50 & 15.50 \\
\hline \multirow[t]{3}{*}{ Oak Ridge, TN } & Special Train 2-way & 4.00 & 4.50 & 14.00 & 22.50 \\
\hline & Special Train 1-way & 4.00 & 2.50 & 13.00 & 19.50 \\
\hline & Regular Train & 4.00 & -- & 11.00 & 15.00 \\
\hline
\end{tabular}

costs increase approximately 30 percent over unit costs for regular trains for both reprocessors. A11 of the special train costs are based on using the most economic number of casks per trip. Conventional freight train costs are based on one cask per trip.

Assuming annual discharge and pickup for each reactor and a net cask use factor of 85 percent, regular train usage would require 19 and 11 shipping casks for shipments to Barnwell and Oak Ridge respectively.

The freight charges for conventional trains and special trains are identical. The average costs used in this study were $\$ 5.00 / \mathrm{kg}$ and $\$ 4.50 / \mathrm{kg}$ for shipments to Barnwell and Oak Ridge respectively.

Spent fuel special trains result in increased terminal times if multiplecask shipments are used. This results in more casks being needed to ship the same quantity of fuel in a year's time. Barnwell would require five and Oak Ridge three additional casks if special train requirements both ways were imposed. The increased cask use charges amount to about $\$ 2.50 / \mathrm{kg}$ and $\$ 3.00 / \mathrm{kg}$ for Barnwell and Oak Ridge respectively.

Special train charges account for the rest of the difference in unit charges. These average $\$ 5.50 / \mathrm{kg}$ for Barnwe 11 and $\$ 4.50 / \mathrm{kg}$ for Oak Ridge. 
Sensitivity of the Study Parameters

Table 7 summarizes results of a sensitivity analysis for the study's variables. Average train speed varies as a function of many factors including yard time and crew changes. In this study it is used to describe the total transit time for shipments between a reactor site and a reprocessing site. A wide range of average speeds was used to identify the cost-sensitivity of this parameter. The reference case study assumed that special train and conventional freight train speeds were identical and equal to $6.4 \mathrm{mph}$. This number was determined from an average of transit times given for conventional freight service in Table A-2. If the average speed of special trains were reduced to one-half that of regular train speeds, costs would be increased $\$ 7.00 / \mathrm{kg}$ or 30 percent. If the average speed of special trains were three times greater than regular trains, costs would be reduced 21 percent or $\$ 5.00 / \mathrm{kg}$.

TABLE 7. Sensitivity Analysis for Spent Fuel Shipping Parameters, Special Train Required in Both Directions (Based on Barnwe11, SC Data)

\begin{tabular}{|c|c|c|c|c|}
\hline Parameter & $\begin{array}{c}\text { Parameter } \\
\text { Reference } \\
\text { Value }\end{array}$ & $\begin{array}{l}\text { Parameter } \\
\text { Variation }\end{array}$ & $\begin{array}{l}\text { Percent } \\
\text { Change } \\
\end{array}$ & $\begin{array}{l}\text { Cost } \\
\text { Change } \\
\text { Percent } \\
\end{array}$ \\
\hline \multirow[t]{3}{*}{ Average Train Speed } & $6.4 \mathrm{mph}$ & $3.2 \mathrm{mph}$ & -50 & +30 \\
\hline & $6.4 \mathrm{mph}$ & $12.8 \mathrm{mph}$ & +100 & -17 \\
\hline & $6.4 \mathrm{mph}$ & $19.2 \mathrm{mph}$ & +200 & -21 \\
\hline \multirow{2}{*}{ Cask Terminal Times } & 5 days/cask & 3 days/cask & -40 & -11 \\
\hline & 5 days/cask & 7 days/cask & +40 & +9 \\
\hline \multirow[t]{2}{*}{ Cask Use Charges } & $\$ 2,500 /$ day & $\$ 3,000 /$ day & +20 & +9 \\
\hline & $\$ 2,500 /$ day & $\$ 2,000 /$ day & -20 & -13 \\
\hline Special Train Charges & $\$ 39,400 /$ trip $^{(a)}$ & $\$ 59,200 /$ trip & +50 & +11 \\
\hline
\end{tabular}

(a) This is the average special train cost to 51 different reactor locations. 
Cask terminal times influence cost by affecting the trip times and, therefore, affecting the total number of casks required during a given time period. Increasing cask turnaround times from 5 to 7 days increased unit costs by 9 percent or $\$ 2.00 / \mathrm{kg}$. Decreasing terminal time from 5 to 3 days lowered unit costs by $\$ 2.50 / \mathrm{kg}$ or 11 percent.

If cask use charges are increased by 20 percent, unit costs increase 9 percent. If cask use charges are decreased by 20 percent, unit costs decrease by 13 percent. The effect of this parameter is diluted, however, since it affects comparative costs only when special train and conventional freight train transit and terminal times differ.

Special train charges have a relatively minor effect on total unit costs. An increase of 50 percent in special train charges results in only an 11 percent increase in the unit costs.

The most cost-sensitive parameter is cask size. Increasing the cask size from 4.52 MT to 6.75 MT (50 percent increase) reduces the unit cost by $\$ 4.50 / \mathrm{kg}$ or 20 percent. Use of a smaller 3.25-MT cask for all shipments increases the unit cost by 31 percent. However, this parameter does not enter into direct comparison of special train and conventional freight train costs since it affects both nearly equally. The parameter study is presented here for completeness and background information.

\section{ANALYSIS OF COST PARAMETERS}

The following sections briefly describe the computer code TRAINS and show in detail the effects of variations in parameters on shipment costs. TRAINS Computer Code

This program, developed at PNL, basically determines a lowest-cost, multiple-cask shipping configuration for each reactor and calculates the freight charges, special train charges and cask use charges for this configuration. These charges are then summed and averaged for all reactors shipping to a given reprocessor to develop the average charge per kilogram of spent fuel shipped. Details of the program are given in Appendix $C$. 


\section{Effect of Multiple Cask Shipments}

The impact of special train charges can be mitigated to some extent by carrying more than one cask in each shipment. This is illustrated for three sample shipments chosen from the 51 routes analyzed. Table 8 shows the parameters for these reference shipments. The table shows the distance, the annual tonnage shipped, the amount of freight charges, the special train charges, and the estimated transit time and average speed for regular trains. The quantity to be shipped is important because it affects the number of casks required; for example, the Watts Bar shipments were to be 24.8 tons per year. This would require six cask shipments to be made. The significance of the special train charges relative to the freight charges is also seen in the table. For example, on a 3,000-mile shipment total freight charges will be about $\$ 42,220$ and the special train charge for just one way is $\$ 56,770$. For the reference case, the analysis assumed that special trains will travel at the same average speed as regular trains.

The costs of the sample shipments are shown in Figure 8 and detailed in Table 9. Multiple casks have no advantage for the 100-mile shipment. On a $\$ / \mathrm{kg}$ basis, the reduction in special train charges is overshadowed by the increased cask use charges. For the 810-mile shipment, the shipping costs on $\$ / \mathrm{kg}$ basis are less for a two-cask shipment and increase again at three casks. For the 2,990-mile shipment, three casks are optimum but there are only small differences between the two, three, or four-cask shipping costs.

\section{Effect of Cask Size}

The capacity of the cask has a significant impact on the cost of spent fuel shipments, as illustrated in Figure 9. Using the reference cask with a capacity of 4.52 MT, it was found that a smaller cask (3.25 MT) increased costs by about 30 percent. A larger cask ( 6.75 MT) decreased costs by about 20 percent. It should be noted that cask size does not affect the comparative costs of shipping by conventional freight or special trains. However, it does affect terminal times and thus indirectly affects the total comparative costs. 
TABLE 8. Sample Reactor-Destination Parameters

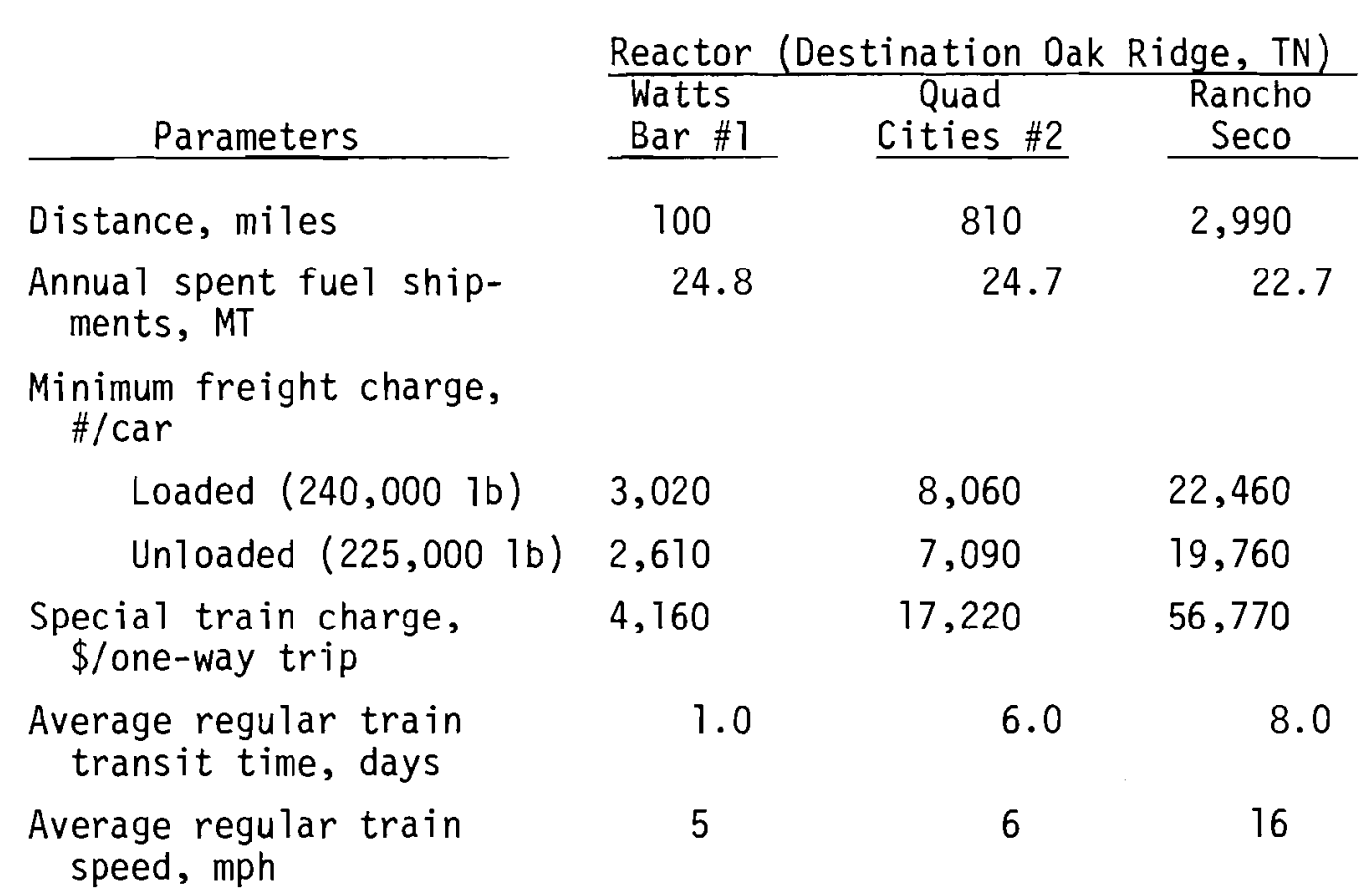

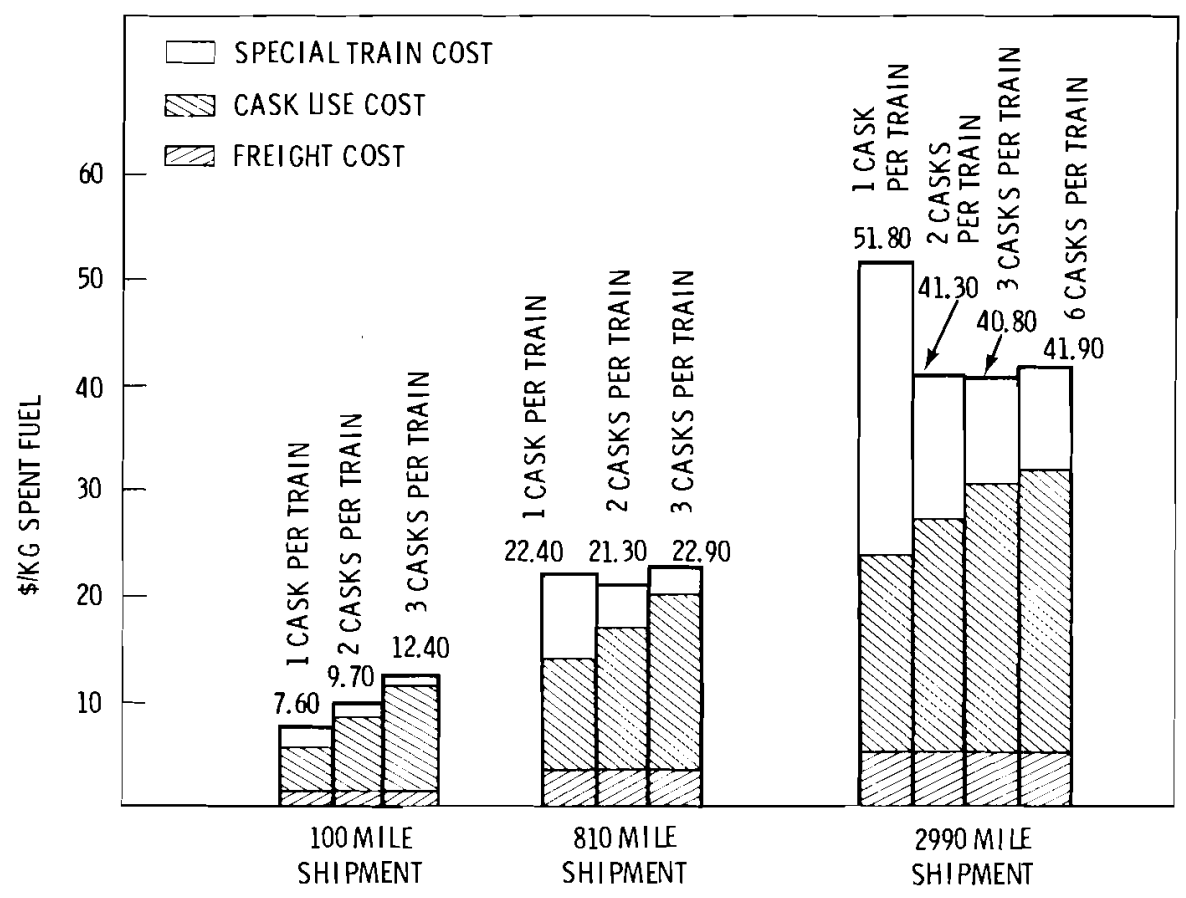

FIGURE 8. Effect of Multiple Cask Shipments for Selected Reactor Destinations (Special Train Both Directions) 


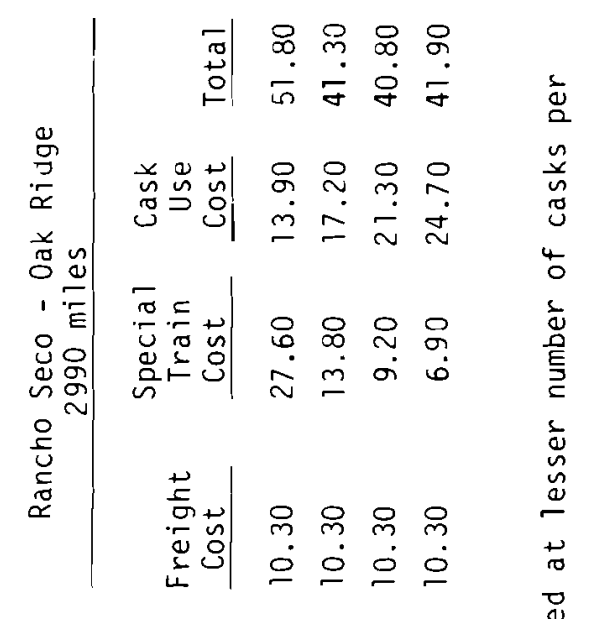

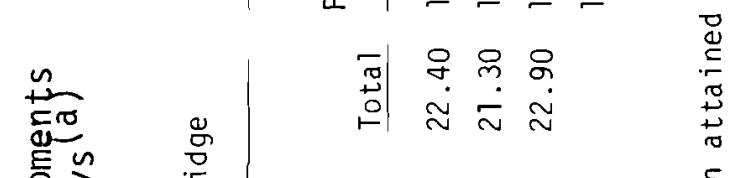

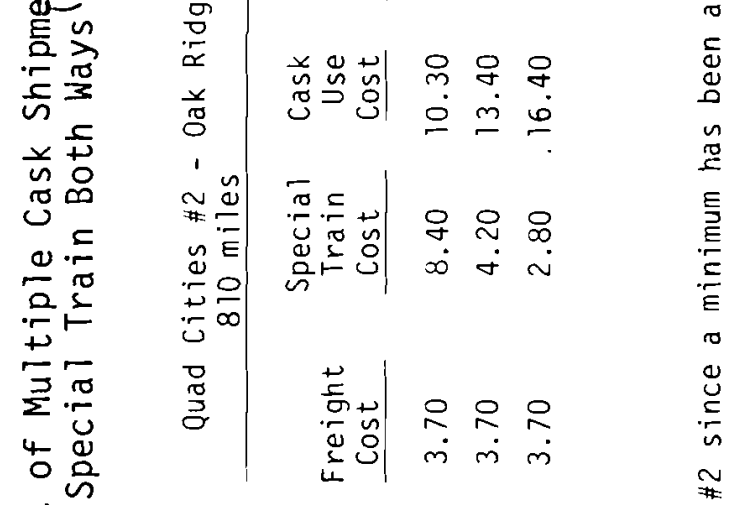

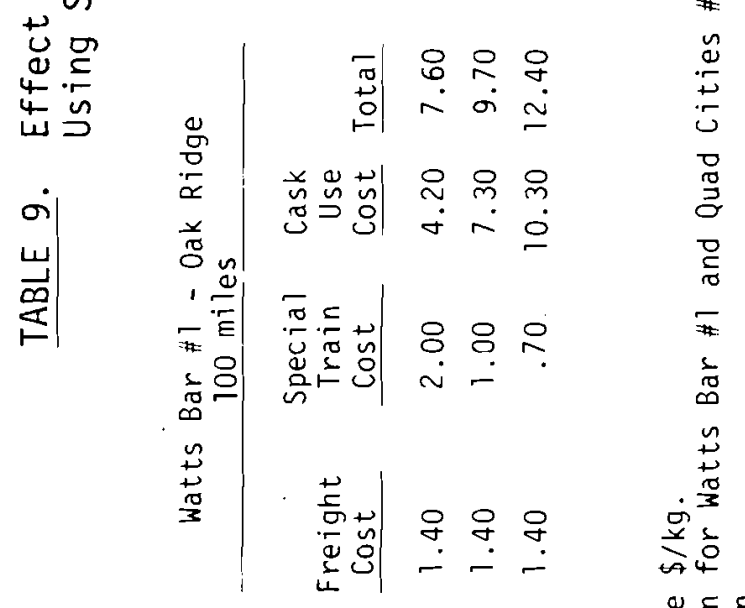

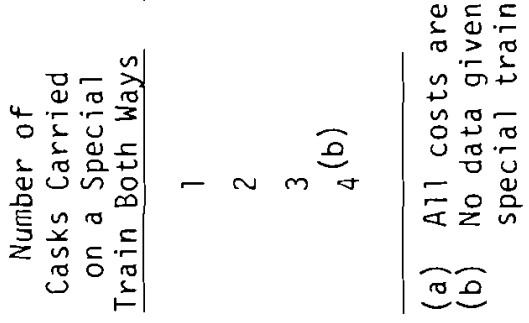




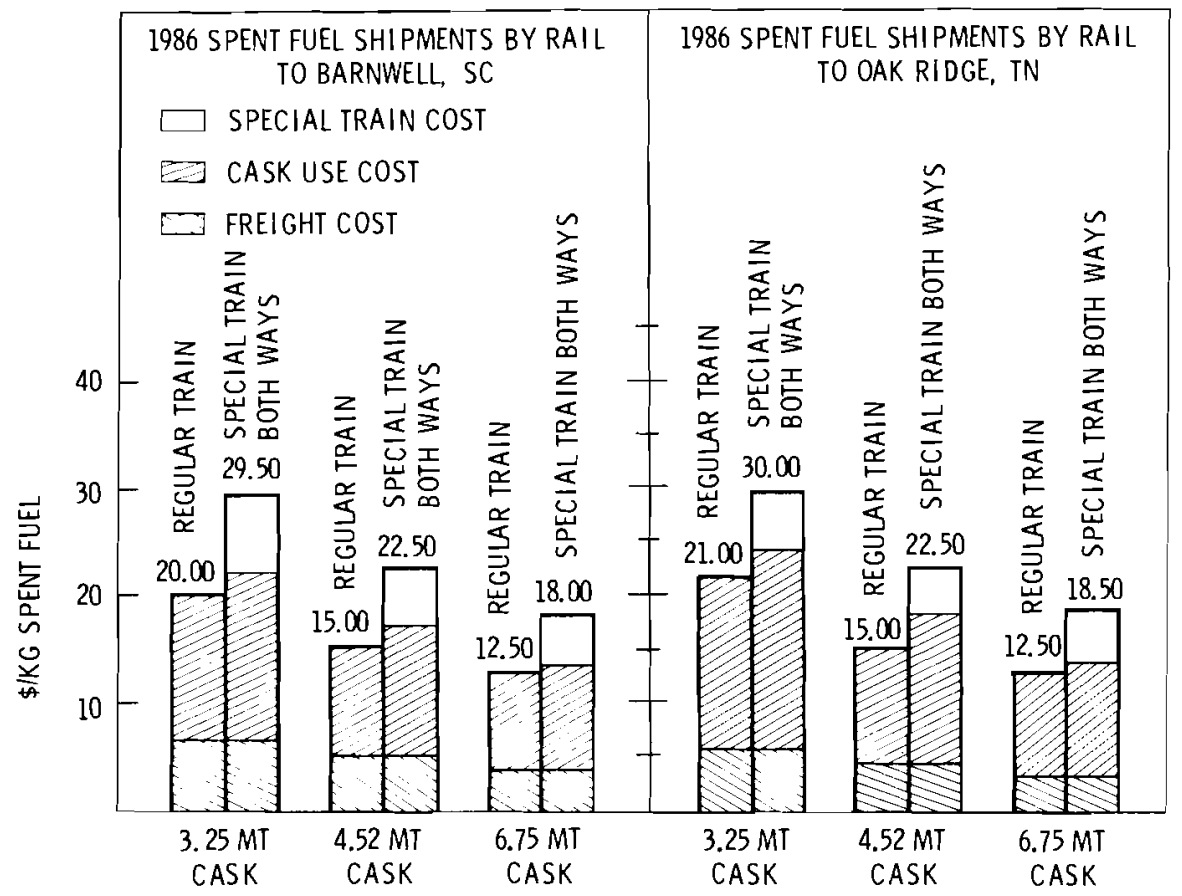

FIGURE 9. Effect of Cask Size on 1986 Shipping Costs

\section{Effect of Cask Terminal Time}

Another uncertainty in estimating shipping costs is the terminal time, that is, the time required for loading and unloading the casks plus the time waiting for the rail pickup. We assumed a range of 4 to 6 days for terminal time for single cask shipments. Discussions with AGNS indicated that they estimate terminal times of 3 days at the reactor and 2 days at the reprocessing plant.

Terminal time is greater for multiple cask shipments in special trains (Table 4) because of the waiting time necessary while loading and unloading casks. Figure 10 illustrates the impact of this uncertainty on the total shipping costs. For the regular train shipment this uncertainty amounts to approximately $\$ 2.00 / \mathrm{kg}$ regardless of distance shipped. However, for the special train shipments with multiple casks the effect is greater because each cask must wait while the other casks are loaded. The effect of this parameter on special trains to and from Barnwe11, SC is about $\$ 4.50 / \mathrm{kg}$. 


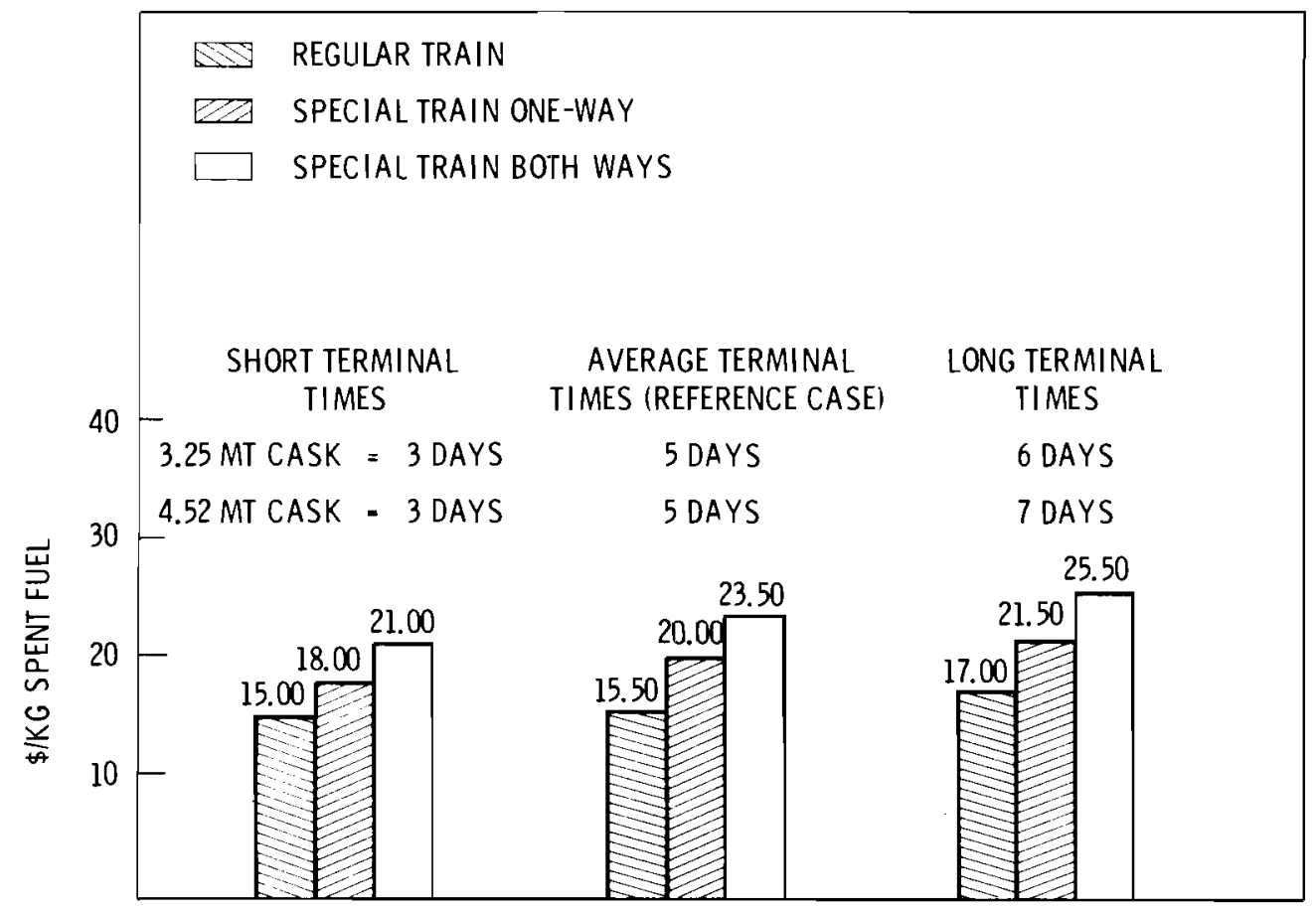

FIGURE 10. Effect of Cask Terminal Time on 1986 Shipping Costs to Barnwel1, SC

\section{Effect of Cask Use Charges}

Cask use charges affect the shipping cost and disproportionately increase the cost of special train shipments. This is illustrated in Figure 11. A range of use charges from $\$ 2,000 /$ day to $\$ 3,000 /$ day was considered. In the case of Barnwell shipments, the effect is approximately $\$ 5.00 / \mathrm{kg}$ for either regular train or special train. For Oak Ridge shipments (not shown in figure) the effect is about $\$ 6.00 / \mathrm{kg}$.

\section{Effect of Train Speed}

The comparative costs of spent fuel shipments are affected significantly by the average rates of travel for the special trains relative to the conventional trains. Estimates of relative speeds range from one-half to three times as fast as regular freight. The effect of this range of uncertainties for the Barnwell and Oak Ridge shipments is shown in Figure 12. The effect of doubling the train speed reduces the cost from $\$ 23.50 / \mathrm{kg}$ to $\$ 19.50 / \mathrm{kg}$ or $\$ 4.00 / \mathrm{kg}$ for special trains in both directions. The effect of reducing this speed by half increases the cost from $\$ 23.50 / \mathrm{kg}$ to $\$ 30.50 / \mathrm{kg}$ or approximately $\$ 7.00 / \mathrm{kg}$. 


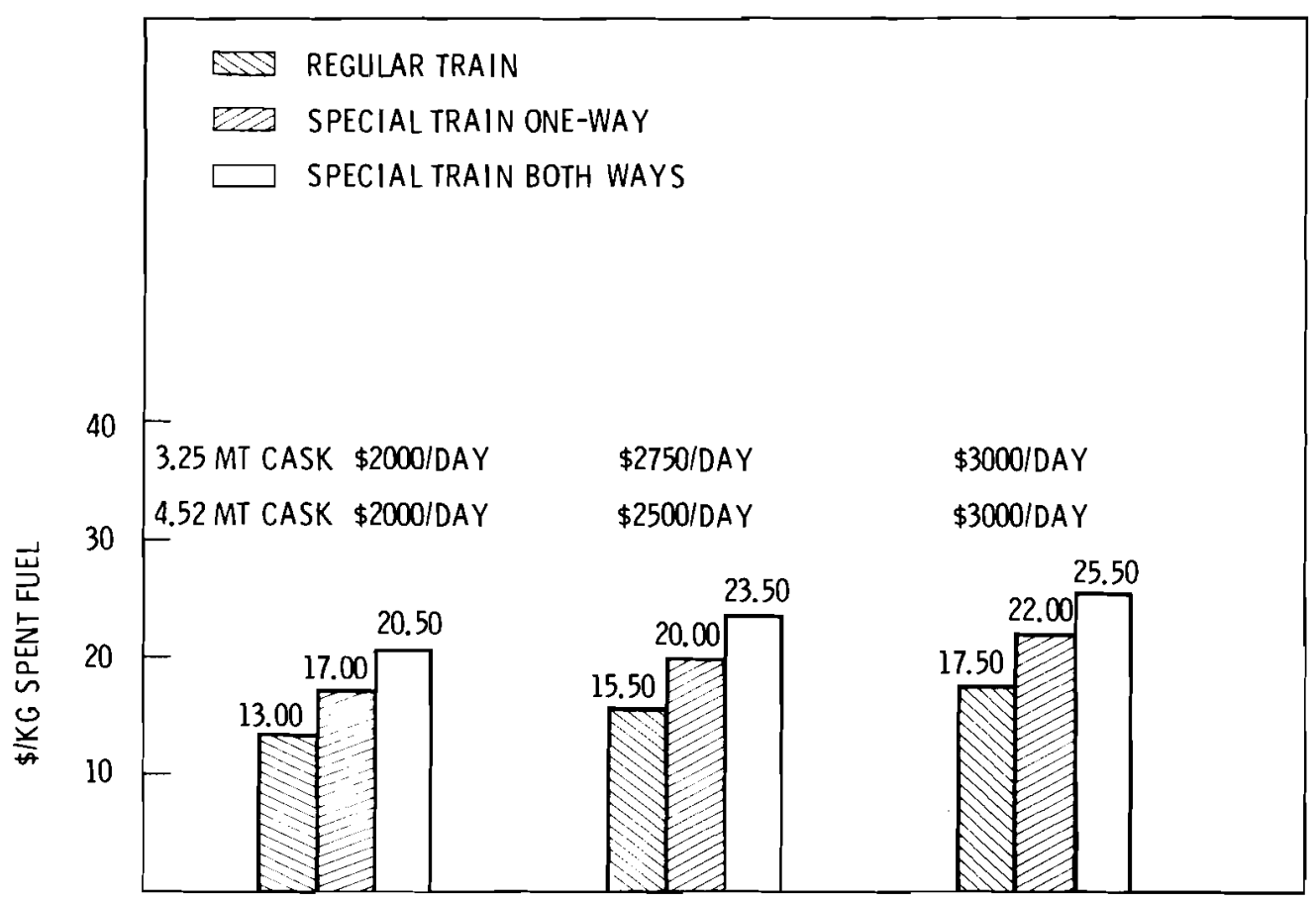

FIGURE 11. Effect of Cask Use Charges on 1986 Shipping Costs to Barnwel1, SC

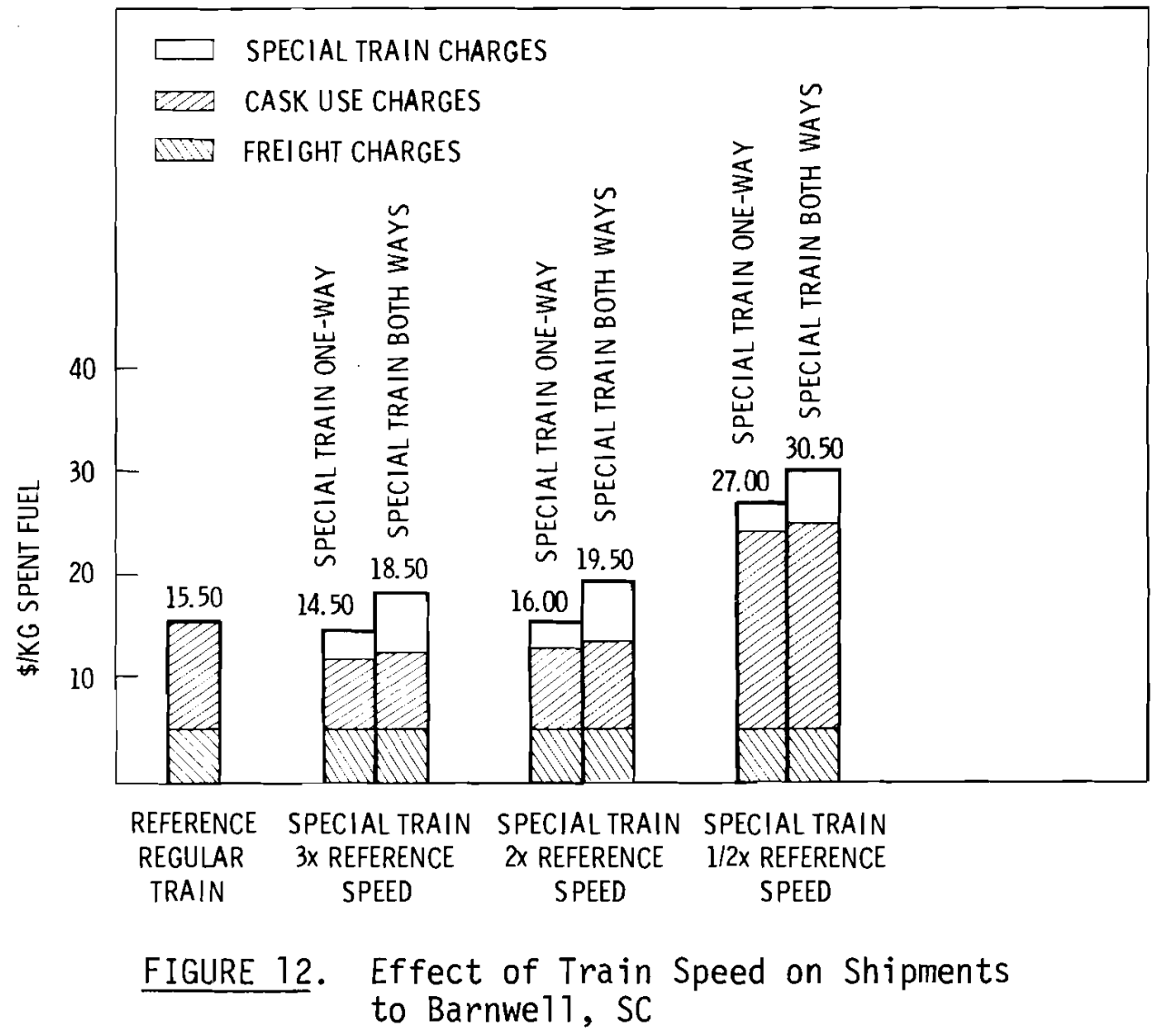


The average speed of a spent fuel special train is seen to be an important determinant in the cost of shipping spent fuel. Since there has been little experience with special trains of the type that are proposed for spent fuel, the average speed that spent fuel special trains might actually travel was not apparent. Although special trains for other commodities often travel at average speeds greater than the average speed of conventional freight trains, several factors suggest that this may not be the case for spent fuel special trains. Unless spent fuel special trains receive priority for movement on high traffic density lines their average speeds will be reduced by the passing and speed restrictions. Alternative routing around high traffic density lines could reduce this problem, but the extra distance traveled would still decrease average train speeds. The passing restriction may also create congestion and slow train movements near reprocessing sites, which may receive and ship several special trains of radioactive material each day.

Effect of Special Train Charges

The effects of variance in special train charges are shown in Figure 13. Increasing special train charges 50 percent increases the unit costs for shipments to Barnwel1 by $\$ 2.50 / \mathrm{kg}$ for a two-way special train and $\$ 1.00 / \mathrm{kg}$ for one-way or about 10 percent. This parameter appears to have less impact on shipping costs than the other parameters.

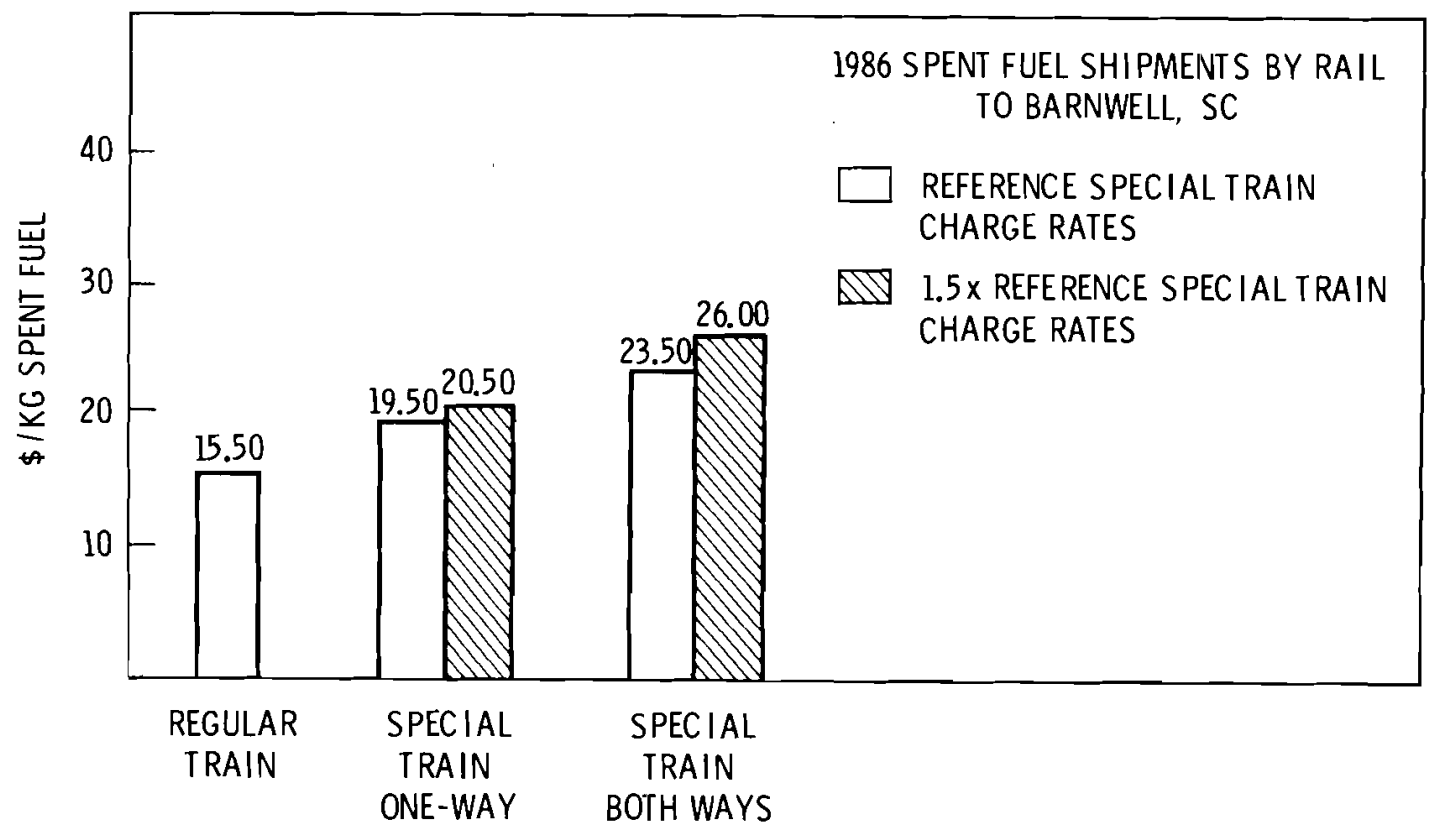

FIGURE 13. Effect of Special Train Charges 
Range of Unit Costs for Special Trains

A range of maximum, most likely, and minimum special train costs was estimated to reflect the uncertainties associated with the cost components of spent fuel shipments. Table 10 lists the parameter values associated with the estimate of each component. The most likely estimate used the reference case parameters previously described. The cost ranges are shown in Figure 14. A11 special train costs are for special trains in both directions. The graph shows that under parameter conditions most favorable to reducing special train costs, unit costs can be as much as $\$ 3.00 / \mathrm{kg}$ less than regular train costs. However, under least favorable conditions, unit costs could be as much as $\$ 32 / \mathrm{kg}$ more than regular train costs. Most likely estimates place special train unit costs about $\$ 8 / \mathrm{kg}$ higher than regular train costs.

\section{IMPACT OF SPECIAL TRAIN REQUIREMENTS ON RAILROAD REVENUES}

An alternate approach that has been used to evaluate the economic impact of the mandatory special train service is to determine the change in railroad revenues that would result from the use of special trains (see Appendix $D$ ). A number of studies $(29,30)$ have assessed this cost impact assuming in their calculations that a special train contains only one cask car. This analysis has extend the results of previous work for special trains containing from one to five cask cars. The reference case parameters defined in the previous section are used here.

The results of the analysis are presented in Table 11. Calculations were made for the cost of shipping spent fuel from three reactor sites to a proposed reprocessing plant in 0ak Ridge, TN. A11 costs are in 1976 constant dollars. Special trains both ways included minimum weight requirements in both the loaded $(240,000 \mathrm{lb})$ and empty $(225,000 \mathrm{lb})$ directions.

The increases in round-trip revenues range from 29 percent for a 5-car shipment to 267 percent for a 1-car shipment. The average increase in roundtrip revenues for a 5 -car shipment is about 50 percent. For a 1-car shipment the average increase in revenues is about 250 percent. However, the first would not be a practical mode of operation for the nuclear power industry 
TABLE 10. Parameter Values for High, Low and Most Likely (Reference) Unit Costs for Special Trains

\begin{tabular}{|c|c|c|c|}
\hline Parameter & $\begin{array}{l}\text { Low } \\
\text { Special Train } \\
\text { Shipping Cost }\end{array}$ & $\begin{array}{l}\text { Most Likely } \\
\text { (Reference) } \\
\text { Special Train } \\
\text { Shipping Cost } \\
\end{array}$ & $\begin{array}{l}\text { High } \\
\text { Special Train } \\
\text { Shipping Cost }\end{array}$ \\
\hline Year & 1986 & 1986 & 1986 \\
\hline Cask Size, MT & 6.75 & 4.52 & 3.25 \\
\hline Cask use charge, $\$ /$ day & 3,000 & 2,500 & 2,500 \\
\hline Cask turnaround time, days & 4 & 5 & 6 \\
\hline $\begin{array}{l}\text { Train speed (fraction of regu- } \\
\text { lar train speed) }\end{array}$ & 3.0 & 1.0 & 0.5 \\
\hline $\begin{array}{l}\text { Special train charges relative } \\
\text { to reference special train } \\
\text { charges }\end{array}$ & 1.0 & 1.0 & 1.5 \\
\hline
\end{tabular}

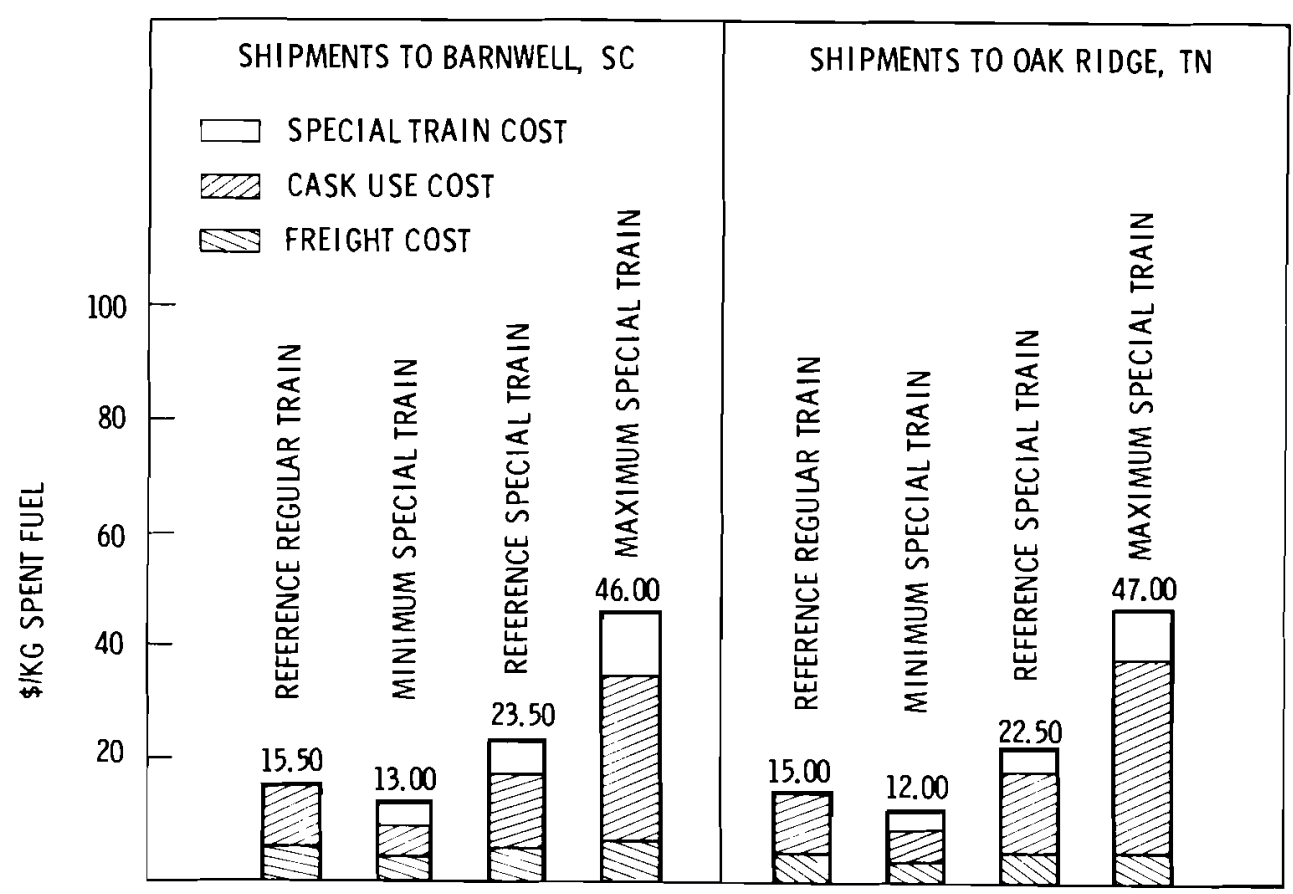

FIGURE 14. Estimated Maximum and Minimum Unit Costs of Using Special Trains Shown with Reference Case Costs 
TABLE 11. Increase in Railroad Revenues Due to Spent Fue 1 Special Train Requirements Both Ways $(a)$

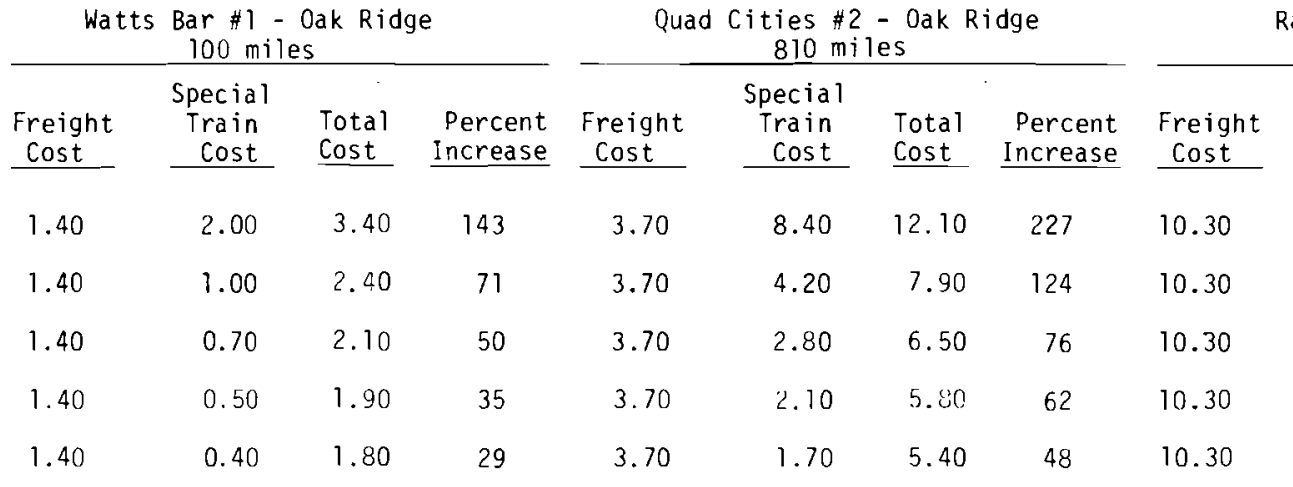

Rancho Seco - Oak Ridge

Number of

Casks Carried

on a Special

Train Both Ways

1.40

0.40

3.70

$1.70 \quad 5.40 \quad 48$

10.30 Special

cost cost Increase

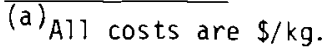

$\begin{array}{rrr}27.60 & 37.90 & 267 \\ 13.80 & 24.10 & 134 \\ 9.20 & 19.50 & 89 \\ 6.90 & 17.20 & 67 \\ 5.50 & 15.80 & 53\end{array}$


since it would require a large number of spent fuel casks. This is a result of the number of casks that must await shipping while one cask is being loaded. These results are consistent with References 29 and 30.

\section{SUMMARY OF ECONOMIC ANALYSIS}

The economic analysis of shipping costs showed that the special train requirements will probably increase average costs of spent fuel shipments about 50 percent and could as much as 200 percent. Under favorable conditions, a cost saving of 20 percent could be achieved. The costs of shipping by special trains could be expected to vary from $\$ 13.00 / \mathrm{kg}$ to $\$ 46.00 / \mathrm{kg}$ for average shipments to Barnwell, SC. Most likely costs, based on an optimal number of cask cars per special train, are expected to be about $\$ 23.50 / \mathrm{kg}$. The average conventional freight shipping costs, based on one cask car per train, are $\$ 15.50 / \mathrm{kg}$ in 1976 dollars. Thus the expected average increase of shipping spent fuel by special train is 50 percent. The costs for shipments to Oak Ridge are similar.

Economic analysis in terms of railroad revenues that included only freight and special train charges showed that the cost of special trains will be 50 percent to 250 percent higher depending on the number of cask cars used in each special train. Single cask car shipments will result in greatest increases in railroad revenue. Multiple cask car shipments reduce special train costs in inverse proportion to the number of cask cars since the special train charge is independent of the number of cask cars in a train. However, multiple cask car shipments will require a large number of cask cars because of long waiting periods while one cask car is being loaded and thus may not be a practical alternative for the shipper.

The sensitivity analysis of the parameters affecting the cost of spent fuel shipments indicated cask size to be the most cost-sensitive parameter. Defining elasticity factor as the ratio of percent change in cost to the percent changes in a specific parameter, the elasticity factor for cask size was found to be nearly unity. Other elasticity factors were found to be about 0.50 for cask use charges, 0.25 for cask terminal time, 0.20 for special train charges, and 0.20 for train speed. These factors reflect the significance of spent fuel casks in the overall economics of spent fuel shipping. 


\section{REFERENCES}

1. Department of Transportation, Hazardous Material Regulations, Title 49, Code of Federal Regulations, Parts 170-174.

2. Atomic Energy Commission, Packaging of Radioactive Materials for Transportation, Title 10, Code of Federal Regulations, Part 71.

3. The Environmental Impact of Transportation of Nuclear Materials in the LMFBR Program, ERDA-40, USERDA, Washington, DC, May 1975.

4. J. W. Langhaar, "Transport Experience with Radioactive Materials," Proceedings of the International Symposium on the Management of Wastes from the LWR Fuel Cycle, Denver, CO, July 11-16, 1976, CONF-76-0701, p. 469.

5. 0. A. Kelly and W. C. Stoddart, Highway Vehicle Impact Studies: Tests and Mathematical Analyses of Vehicle, Package and Tiedown Systems Capable of Carrying Radioactive Material, ORNL-NSIC-61, Nuclear Safety Information Center, Oak Ridge National Laboratory, Oak Ridge, TN, February 1970.

6. L. B. Shappert, A Guide for the Design and Operation of Shipping Casks for Nuclear Application, Cask Designers Guide, ORNL-NSIC-68, Nuclear Safety Information Center, Oak Ridge National Laboratory, Oak Ridge, TN, February 1970.

7. A. E. Spaller, Structural Analysis of Shipping Casks: Resistance to Puncture, ORNL-TM-1312, Vol. 2, Oak Ridge National Laboratory, Oak Ridge, TN, September 1966.

8. L. B. Shappert and J. H. Evans, The Obsolete Cask Program: Initial Tests, ORNL-TM-1312, Vo1. 14, Oak Ridge National Laboratory, Oak Ridge, TN, November 1974.

9. G. P. Wachte11, "Drop and Fire Tests of Half-Scale Model of TN-9 Shipping Container," Proceedings of the Fourth International Symposium on Packaging and Transportation of Radioactive Materials, CONF-740901, Miami Beach, FL, September 1974.

10. H. R. Yoshimura and M. Huerte, Full Scale Tests of Spent-Nuclear-Fuel Shipping Systems, SAND 76-5707, Sandia Laboratories, Albuquerque, NM, July 1976.

11. L. B. Shappert et a1., "The Ful1 Scale Cask Program at ORNL," International Seminar on the Design, Construction and Testing of Packaging for the Safe Transport of Radioactive Materials, IAEA-SR-10/6, Vienna, Austria, August 1976. 
12. Board of Directors of the AAR, Movement of Spent Nuclear Fuel Elements, Memorandum to Railroad Industry, May 3, 1974.

13. R. K. Clarke, J. T. Foley, W. F. Hartman and D. W. Larson, Severities of Transportation Accidents, Volume IV - Train, SLA-74-0001, Sandia Laboratories, A1buquerque, NM, September 1975.

14. Nuclear Regulatory Commission, Public Documents, Docket 71-9001 and Docket 71-9023.

15. Train accident tapes for 1972, 73, and 74. Provided by the Office of Safety of the Federal Railroad Administration. These tapes summarize accident data from train accident T-Sheets.

16. Supplement 1 to Western Railroads Freight Tariff 1-B, Special Train Service Tariff, Issued by W. J. Harden, Chicago, IL, Effective July 25, 1975.

17. Hearings before the Interstate Commerce Commission, Docket No. 36307 et al., Radioactive Materials, Missouri-Kansas-Texas Railroad Co., Washington, DC.

18. Department of Transportation, Hazardous Material Regulations, Title 49, Code of Federal Regulations, Part 225, 1974.

19. Rules Governing the Monthly Reports of Railroad Accidents, 1968 Revision, Department of Transportation, Federal Railroad Administration, Washington, DC.

20. Yearbook of Railroad Facts, 1975 Edition, Association of American Railroads, Washington, DC.

21. Final Phase 01 Report on Accident Review, - Railroad Tank Car Safety Research and Test Project, RA-01-4-16, Association of American Railroads, Railway Progress Institute, Chicago, IL, June 30, 1972.

22. Railroad Tank Car Safety Research and Test Project, Phase 08 Report on Computer Derailment Study, FA-08-1-12, Association of American Railroads, Chicago Research Center, Chicago, IL, February 1972.

23. L. B. Shappert et a1., "Probability and Consequences of Transportation Accidents Involvino Radioactive Material Shipments in the Nuclear Fuel Cycle," Nuclear Safety, 14(6).

24. Track Train Dynamics, Publication R-122, Association of American Railroads, 1973.

25. W. Silver, Damage Abatement Test Report: Railroad Shipment Study on HTX-DHX Tube Bundle, Westinghouse, Baltimore, MD, June 1974. 
26. Final Generic Environmental Statement on the Use of Recycle Plutonium in Mixed Oxide Fuel in Light Water Cooled Reactors, NUREG-0002, U.S. Nuclear Regulatory Commission, Washington, DC, August 1976, p. IV G-4.

27. Persona 1 Communication W. F. Hartman, Sandia Laboratories, Albuquerque, NM, to W. V. Loscutoff, Battelle, Pacific Northwest Laboratories.

28. J. W. Langhaar, "Transport Experience with Radioactive Materials," Proceedings of the International Symposium on the Management of Waste from the LWR Fuel Cycle, CONF-76-0701, Denver, C0, 1976, p. 469.

29. J. F. Donelan and J. Guandolo, "Joint Protest Against and Petition for Suspension and Investigation of Uniform Freight Classification 12," I.C.C. 8, Supplement 3, AGNS and NLI, December 19, 1975.

30. G. P. Rifakes, Testimony before the Interstate Commerce Commission, Docket No. 36325. 
$-$ 
APPENDIX A

TRANSPORT NETWORK MODEL FOR SPENT

FUEL SHIPMENTS IN 1986 


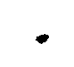




\section{TABLE A-1. Plants Shipping Spent Fuel in 1986}

\begin{tabular}{|c|c|}
\hline $\begin{array}{l}0 / 0 \\
\text { No. }\end{array}$ & Plant \\
\hline $\begin{array}{l}1 \\
2 \\
3 \\
4 \\
5\end{array}$ & $\begin{array}{l}\text { Arkansas } 1,2 \\
\text { Bailiy } \\
\text { Beaver Valley } 1,2 \\
\text { Braidwood } 1,2 \\
\text { Brunswick 1,2 }\end{array}$ \\
\hline $\begin{array}{l}6 \\
8 \\
9\end{array}$ & $\begin{array}{l}\text { Comanche Peak 1, } 2 \\
\text { Cooper }\end{array}$ \\
\hline & $\begin{array}{l}\text { Comanche Peak } 1,2 \\
\text { Cook } 1,2\end{array}$ \\
\hline $\begin{array}{r}8 \\
6 \\
7 \\
8 \\
9 \\
10\end{array}$ & $\begin{array}{l}\text { Comanche Peak } 1,2 \\
\text { Cook } 1,2 \\
\text { Cooper } \\
\text { Crysta River } \\
\text { Davis Besse 1, } 2\end{array}$ \\
\hline $\begin{array}{l}11 \\
12 \\
13 \\
14 \\
15\end{array}$ & $\begin{array}{l}\text { Duane Arnold } 1 \\
\text { Enrico Fermil } \\
\text { Farley } 1,2\{a\} \\
\text { Fort Calhoun } 1,2 \\
\text { Fitzpatrick } 1\end{array}$ \\
\hline $\begin{array}{l}16 \\
17 \\
18 \\
19 \\
20\end{array}$ & $\begin{array}{l}\text { Forked River } 1 \\
\text { Ginna 1(a) } \\
\text { Hatch 1,2 } \\
\text { Hope Creek 1, } 2 \\
\text { LaSa1le 1,2 }\end{array}$ \\
\hline $\begin{array}{l}21 \\
22 \\
23 \\
24 \\
25\end{array}$ & $\begin{array}{l}\text { Limerick } 1,2 \\
\text { Maine Yankee } \\
\text { McGuire 1,2 } \\
\text { Midland 1,2 } \\
\text { Millstone 1,2, } 3\end{array}$ \\
\hline $\begin{array}{l}26 \\
27 \\
28 \\
29 \\
30\end{array}$ & $\begin{array}{l}\text { Monticel lo } \\
\text { North Anna } 1,2,3,4 \\
\text { Oconee } 1,2,3(a) \\
\text { Oyster Creek } 1 \\
\text { Palisades }(a)\end{array}$ \\
\hline $\begin{array}{l}31 \\
32 \\
33 \\
34 \\
35\end{array}$ & $\begin{array}{l}\text { Peach Bottom 2, } 3^{(a)} \\
\text { Prairie Island } 1,2 \\
\text { Quad Cities 1, 2 } \\
\text { Rancho Seco } \\
\text { Robinson } 2\end{array}$ \\
\hline $\begin{array}{l}36 \\
37 \\
38 \\
39 \\
40\end{array}$ & $\begin{array}{l}\text { San Onofre } 1,2,3 \\
\text { Sequoyah } 1,2 \\
\text { Susquehanna 1, } 2 \\
\text { Three Mile Isiand, } 1,2 \\
\text { Trojan }\end{array}$ \\
\hline $\begin{array}{l}41 \\
42 \\
43 \\
44 \\
45\end{array}$ & $\begin{array}{l}\text { Virgil Summer } \\
\text { Vermont Yankee } \\
\text { Waterford } \\
\text { Watts Bar } 1,2 \\
\text { WPPSS } 1,2,3,4,5\end{array}$ \\
\hline $\begin{array}{l}46 \\
47 \\
48 \\
49 \\
50\end{array}$ & $\begin{array}{l}\text { Zion } 1,2 \\
\text { Turkey Point } 3,4(a) \\
\text { St. Lucie } 1,2(a) \\
\text { Browns Ferry } 1,2,3(a) \\
\text { Humboldt Bay }\end{array}$ \\
\hline
\end{tabular}

\begin{tabular}{|c|c|}
\hline pment & Origin \\
\hline $\begin{array}{r}11 \\
4 \\
9 \\
11 \\
11\end{array}$ & $\begin{array}{l}\text { Russellville, AR } \\
\text { Gary, IN } \\
\text { Shippingport, PA } \\
\text { Braidwood, IL } \\
\text { Southport, NC }\end{array}$ \\
\hline $\begin{array}{r}11 \\
6\end{array}$ & $\begin{array}{l}\text { Somervell Co., TX } \\
\text { Brownville, NB }\end{array}$ \\
\hline $\begin{array}{l}11 \\
11\end{array}$ & $\begin{array}{l}\text { Somervel1 } 1 \text { Co., TX } \\
\text { Benton Harbor, MI }\end{array}$ \\
\hline $\begin{array}{r}11 \\
11 \\
6 \\
6 \\
11\end{array}$ & $\begin{array}{l}\text { Somervell Co., TX } \\
\text { Benton Harbor, MI } \\
\text { Brownville, NB } \\
\text { Red Level, Tampa, FL } \\
\text { Oak Harbor, OH }\end{array}$ \\
\hline $\begin{array}{r}4 \\
7 \\
14 \\
8 \\
6\end{array}$ & $\begin{array}{l}\text { Ceadar Rapids, IA } \\
\text { Monroe, MI } \\
\text { Dothan, AL } \\
\text { Blair, NB } \\
\text { Oswego, NY }\end{array}$ \\
\hline $\begin{array}{r}7 \\
4 \\
12 \\
15 \\
14\end{array}$ & $\begin{array}{l}\text { Toms River, NJ } \\
\text { Rochester, NY } \\
\text { Baxley, GA } \\
\text { Bordentown, NJ } \\
\text { Seneca, IL }\end{array}$ \\
\hline $\begin{array}{r}15 \\
6 \\
11 \\
11 \\
16\end{array}$ & $\begin{array}{l}\text { Potts town, PA } \\
\text { Portland, ME } \\
\text { Charlotte, NC } \\
\text { Midland, MI } \\
\text { Hartford, CT }\end{array}$ \\
\hline $\begin{array}{r}5 \\
20 \\
23 \\
6 \\
8\end{array}$ & $\begin{array}{l}\text { Monticello, MN } \\
\text { Mineral, VA } \\
\text { Seneca, SC } \\
\text { Toms River, NJ } \\
\text { South Haven, MI }\end{array}$ \\
\hline $\begin{array}{r}18 \\
6 \\
11 \\
5 \\
5\end{array}$ & $\begin{array}{l}\text { Peach Bottom, PA } \\
\text { Redwing, MN } \\
\text { Cordova, IL } \\
\text { Sacramento, CA } \\
\text { Hartsville, SC }\end{array}$ \\
\hline $\begin{array}{l}16 \\
11 \\
14 \\
11 \\
6\end{array}$ & $\begin{array}{l}\text { San Clemente, CA } \\
\text { Chattanooga, TN } \\
\text { Shickshinny, PA } \\
\text { Middletown, PA } \\
\text { Rainier, OR }\end{array}$ \\
\hline $\begin{array}{r}6 \\
4 \\
6 \\
11 \\
32\end{array}$ & $\begin{array}{l}\text { Jenkinsville, SC } \\
\text { Vernon, VT } \\
\text { Norco, LA } \\
\text { Spring City, TN } \\
\text { Richland, WA }\end{array}$ \\
\hline $\begin{array}{r}11 \\
13 \\
14 \\
30 \\
3\end{array}$ & $\begin{array}{l}\text { Zion, Chicago, IL } \\
\text { FL City, Miami, FL } \\
\text { Ft. Pierce, FL } \\
\text { Athens, AL } \\
\text { Eureka, CA }\end{array}$ \\
\hline
\end{tabular}

\begin{tabular}{|c|c|}
\hline Originating Rail Service & Destination \\
\hline $\begin{array}{l}\text { Missouri Pacific } \\
\text { Chicago South Shore \& South Bend } \\
\text { New Cumberland \& Pittsburg } \\
\text { Illinois Central Gulf } \\
\text { Seaboard Coast Line }\end{array}$ & $\begin{array}{l}\text { Oak Ridge, TN } \\
\text { Oak Ridge } \\
\text { Barnwell, SC } \\
\text { Oak Ridge } \\
\text { Barnwell }\end{array}$ \\
\hline $\begin{array}{l}\text { At. Topeka \& Santa Fe } \\
\text { Burlington Northern }\end{array}$ & $\begin{array}{l}\text { Oak Ridge } \\
\text { Oak Ridge }\end{array}$ \\
\hline $\begin{array}{l}\text { At. Topeka \& Santa Fe } \\
\text { Chesapeake \& Ohio }\end{array}$ & $\begin{array}{l}\text { Oak Ridge } \\
\text { Barnwell }\end{array}$ \\
\hline $\begin{array}{l}\text { At. Topeka \& Santa Fe } \\
\text { Chesapeake \& Ohio } \\
\text { Burlington Northern } \\
\text { Seaboard Coast Line } \\
\text { Norfolk \& Western }\end{array}$ & $\begin{array}{l}\text { Oak Ridge } \\
\text { Barnwell } \\
\text { Oak Ridge } \\
\text { Barnwell } \\
\text { Barnwell }\end{array}$ \\
\hline $\begin{array}{l}\text { Chicago, Rock Island \& Pacific } \\
\text { Conrail } \\
\text { Seaboard Coast Line } \\
\text { Chicago \& Northwestern } \\
\text { Conrail }\end{array}$ & $\begin{array}{l}\text { Barnwell } \\
\text { Dak Ridge } \\
\text { Barnwell } \\
\text { Barnwell } \\
\text { Barnwell }\end{array}$ \\
\hline $\begin{array}{l}\text { Conrail } \\
\text { Penn Central } \\
\text { Southern } \\
\text { Conrail } \\
\text { At. Topeka \& Santa Fe }\end{array}$ & $\begin{array}{l}\text { Oak Ridge } \\
\text { Barnwell } \\
\text { Oak Ridge } \\
\text { Oak Ridge } \\
\text { Oak Ridge }\end{array}$ \\
\hline $\begin{array}{l}\text { Conrail } \\
\text { Maine Central } \\
\text { Seaboard Coast Line } \\
\text { Chesapeake \& Ohio } \\
\text { Penn Central }\end{array}$ & $\begin{array}{l}\text { Oak Ridge } \\
\text { Barnwell } \\
\text { Barnwell } \\
\text { Oak Ridge } \\
\text { Barnwell }\end{array}$ \\
\hline $\begin{array}{l}\text { Burlington Northern } \\
\text { Chesapeake \& Ohio } \\
5 \mathrm{mi} \text { (truck) to Southern } \\
\text { Conrail } \\
\text { Chesapeake \& Ohio }\end{array}$ & $\begin{array}{l}\text { Oak Ridge } \\
\text { Barnwell } \\
\text { Barnwell } \\
\text { Barnwell } \\
\text { Barnwell }\end{array}$ \\
\hline $\begin{array}{l}\text { Maryland \& Pennsylvania } \\
\text { Chicago, Milw. St. Paul \& Pacific } \\
\text { Chicago, Milw. St. Paul \& Pacific } \\
\text { Southern Pacific } \\
\text { Seaboard Coast Line }\end{array}$ & $\begin{array}{l}\text { Barnwell } \\
\text { Oak Ridge } \\
\text { Oak Ridge } \\
\text { Oak Ridge } \\
\text { Barnwell }\end{array}$ \\
\hline $\begin{array}{l}\text { At. Topeka \& Santa Fe } \\
\text { Southern } \\
\text { Conrail } \\
\text { Conrail } \\
\text { Burlington Northern }\end{array}$ & $\begin{array}{l}\text { Barnwell } \\
\text { Barnwell } \\
\text { Oak Ridge } \\
\text { Barnwell } \\
\text { Oak Ridge }\end{array}$ \\
\hline $\begin{array}{l}\text { Southern } \\
\text { Central Vermont } \\
\text { Texas \& Pacific } \\
\text { Southern } \\
\text { Chicago, Milw. St. Paul \& Pacific }\end{array}$ & $\begin{array}{l}\text { Barnwe } 11 \\
\text { Barnwell } \\
\text { Oak Ridge } \\
\text { Oak Ridge } \\
\text { Barnwell }\end{array}$ \\
\hline $\begin{array}{l}\text { Chicago \& Northwestern } \\
9 \mathrm{mi} \text { (truck) to Florida East Coast } \\
9 \mathrm{mi} \text { (truck) to Florida East Coast } \\
9 \mathrm{mi} \text { (truck) to Southern } \\
\text { Northwestern Pacific }\end{array}$ & $\begin{array}{l}\text { Barnwe } 11 \\
\text { Barnwe11 } \\
\text { Barnwe } 11 \\
\text { Barnwe } 11 \\
\text { Barnwell }\end{array}$ \\
\hline
\end{tabular}

(a) Requires truck and rail shipment using casks with 3.25 MT capacity. All others use casks with 4.52 MT capacity. 


\section{TABLE A-2. Summary of Estimated Freight Charges, Train Miles, Special Train Charges, and Regular Train Transit Time (1986)}

\begin{tabular}{|c|c|c|c|c|c|c|c|c|c|c|}
\hline $\begin{array}{l}0 / 0 \\
\text { No. }\end{array}$ & Origin & estination & $\begin{array}{l}\text { Originating } \\
\text { Railroad }\end{array}$ & \multicolumn{2}{|c|}{$\begin{array}{l}\text { Freight Rate } \\
\$ / 100 \text { bs }(a, b)\end{array}$} & \multicolumn{2}{|c|}{$\begin{array}{l}\text { Freight Charge, } \\
\$ / \text { Car }(a, b, c)\end{array}$} & $\begin{array}{l}\text { Estimated } \\
\text { Trajn- } \\
\text { Miles (d) }\end{array}$ & $\begin{array}{c}\text { Estimated } \\
\text { Special Train } \\
\text { Charge, } \\
\$ / 1-\text { Way }(a, b)\end{array}$ & $\begin{array}{l}\text { Estimated } \\
\text { Regular Train } \\
\text { Transit Time, } \\
\text { Days (d) } \\
\end{array}$ \\
\hline \multicolumn{11}{|c|}{ North Pacific Coast Territory } \\
\hline $\begin{array}{l}40 \\
45\end{array}$ & $\begin{array}{l}\text { Rainier, OR } \\
\text { Richland, WA }\end{array}$ & $\begin{array}{l}\text { OR } \\
\mathrm{B}\end{array}$ & $\begin{array}{l}B N \\
M I\llcorner W\end{array}$ & $\begin{array}{l}9.47 \\
9.11\end{array}$ & $\begin{array}{l}8.85 \\
8.52\end{array}$ & $\begin{array}{l}22,730 \\
21,864\end{array}$ & $\begin{array}{l}19,910 \\
19,770\end{array}$ & $\begin{array}{l}2,920 \\
2,940\end{array}$ & $\begin{array}{l}55,380 \\
55,880\end{array}$ & $\begin{array}{l}9-3 / 4 \\
9\end{array}$ \\
\hline \multicolumn{11}{|c|}{ Pacific South Coast Territory } \\
\hline $\begin{array}{l}50 \\
34 \\
36\end{array}$ & $\begin{array}{l}\text { Eureka, CA } \\
\text { Sacramento, CA } \\
\text { San Clemente, CA }\end{array}$ & $\begin{array}{l}B \\
O R \\
B\end{array}$ & $\begin{array}{l}\text { NWP } \\
\text { SP } \\
\text { ATSF }\end{array}$ & $\begin{array}{r}10.21 \\
9.36 \\
10.21\end{array}$ & $\begin{array}{l}9.59 \\
8.78 \\
9.59\end{array}$ & $\begin{array}{l}24,500 \\
22,460 \\
24,500\end{array}$ & $\begin{array}{l}21,580 \\
19,760 \\
21,580\end{array}$ & $\begin{array}{l}3,340 \\
2,990 \\
2,740\end{array}$ & $\begin{array}{l}63,380 \\
56,770 \\
52,120\end{array}$ & $\begin{array}{l}9-1 / 2 \\
8 \\
8\end{array}$ \\
\hline \multicolumn{11}{|c|}{ Southwestern Territory } \\
\hline $\begin{array}{l}7 \\
6\end{array}$ & $\begin{array}{l}\text { Russellville, AR } \\
\text { Somerville Co, TX }\end{array}$ & $\begin{array}{l}\text { OR } \\
\text { OR }\end{array}$ & $\begin{array}{l}\text { MP } \\
\text { ATSF }\end{array}$ & $\begin{array}{l}3.38 \\
4.30\end{array}$ & $\begin{array}{l}3.17 \\
4.04\end{array}$ & $\begin{array}{r}8,110 \\
10,320\end{array}$ & $\begin{array}{l}7,130 \\
9,090\end{array}$ & $\begin{array}{r}850 \\
1,310\end{array}$ & $\begin{array}{l}16,230 \\
26.540\end{array}$ & $\begin{array}{l}4-1 / 2 \\
5\end{array}$ \\
\hline \multicolumn{11}{|c|}{ Western Trunk Line Territory } \\
\hline $\begin{array}{r}26 \\
32 \\
14 \\
8 \\
11\end{array}$ & $\begin{array}{l}\text { Monticello, MN } \\
\text { Redwing, MN } \\
\text { Blair, NB } \\
\text { Brownville, N8 } \\
\text { Cedar Rapids, IA }\end{array}$ & $\begin{array}{l}O R \\
O R \\
B \\
O R \\
B\end{array}$ & $\begin{array}{l}\text { BN } \\
\text { MILW } \\
\text { CNW } \\
\text { BN } \\
\text { RI }\end{array}$ & $\begin{array}{l}4.37 \\
4.14 \\
5.07 \\
4.14 \\
4.62\end{array}$ & $\begin{array}{l}4.10 \\
3.87 \\
4.76 \\
3.87 \\
4.33\end{array}$ & $\begin{array}{r}10,490 \\
9,940 \\
12,170 \\
9,940 \\
11,090\end{array}$ & $\begin{array}{r}9,220 \\
8,710 \\
10,710 \\
8,710 \\
9,740\end{array}$ & $\begin{array}{l}1,180 \\
1,080 \\
1,340 \\
1,020 \\
1,150\end{array}$ & $\begin{array}{l}22,320 \\
21,010 \\
27,090 \\
19,440 \\
21,810\end{array}$ & $\begin{array}{l}7-3 / 4 \\
6-1 / 2 \\
9 \\
7-3 / 4 \\
8\end{array}$ \\
\hline \multicolumn{11}{|c|}{ Illinois Freight Association Territory } \\
\hline $\begin{array}{r}4 \\
20 \\
46 \\
33\end{array}$ & $\begin{array}{l}\text { Braidwood, IL } \\
\text { Seneca, IL } \\
\text { Zion, IL } \\
\text { Cordova, IL }\end{array}$ & $\begin{array}{l}\mathrm{OR} \\
\mathrm{OR} \\
\mathrm{B} \\
\mathrm{OR}\end{array}$ & $\begin{array}{l}\text { ICG } \\
\text { ATSF } \\
\text { CNW } \\
\text { MILW }\end{array}$ & $\begin{array}{l}2.13 \\
2.13 \\
2.94 \\
3.36\end{array}$ & $\begin{array}{l}2.04 \\
2.04 \\
2.76 \\
3.15\end{array}$ & $\begin{array}{l}5,110 \\
5,110 \\
7,060 \\
8,060\end{array}$ & $\begin{array}{l}4,590 \\
4,590 \\
6,210 \\
7,090\end{array}$ & $\begin{array}{r}720 \\
725 \\
1,060 \\
810\end{array}$ & $\begin{array}{l}17,000 \\
17,050 \\
22,420 \\
17,220\end{array}$ & $\begin{array}{l}5 \\
5 \\
6 \\
6\end{array}$ \\
\hline \multicolumn{11}{|c|}{$\underline{\text { Southern Territory }}$} \\
\hline $\begin{array}{r}37 \\
44 \\
23 \\
5 \\
35 \\
41 \\
28 \\
18 \\
9 \\
48 \\
47 \\
13 \\
49 \\
43 \\
27\end{array}$ & $\begin{array}{l}\text { Chattanooga, TN } \\
\text { Spring City, TN } \\
\text { Charlotte, NC } \\
\text { Southport, NC } \\
\text { Hartsville, SC } \\
\text { Jenkinsvilie, SC } \\
\text { Seneca, SC } \\
\text { Baxley, GA } \\
\text { Red Level JCt, FL } \\
\text { Ft. Pierce, FL } \\
\text { Florida City, FL } \\
\text { Dothan, AL } \\
\text { Athens, AL } \\
\text { Norco, LA } \\
\text { Mineral, VA }\end{array}$ & $\begin{array}{l}B \\
O R \\
B \\
B \\
B \\
B \\
B \\
O R \\
B \\
B \\
B \\
B \\
B \\
O R \\
B\end{array}$ & $\begin{array}{l}\text { SOU } \\
\text { SOU } \\
\text { SCL } \\
\text { SCL } \\
\text { SCL } \\
\text { SOU } \\
\text { SOU } \\
\text { SOU } \\
\text { SCL } \\
\text { FEC } \\
\text { FEC } \\
\text { SCL } \\
\text { SOU } \\
\text { TP } \\
\text { CO }\end{array}$ & $\begin{array}{l}2.49 \\
1.26 \\
1.81 \\
2.04 \\
1.55 \\
1.51 \\
1.81 \\
2.74 \\
2.45 \\
2.80 \\
3.17 \\
2.49 \\
2.87 \\
3.30 \\
2.74\end{array}$ & $\begin{array}{l}2.31 \\
1.16 \\
1.71 \\
1.89 \\
1.44 \\
1.40 \\
1.71 \\
2.57 \\
2.27 \\
2.61 \\
2.99 \\
2.31 \\
2.69 \\
3.08 \\
2.57\end{array}$ & $\begin{array}{l}5,980 \\
3,020 \\
4,340 \\
4,900 \\
3,720 \\
3,620 \\
4,340 \\
6,580 \\
5,880 \\
6,720 \\
7,610 \\
5,980 \\
6,890 \\
7,920 \\
6,580\end{array}$ & $\begin{array}{l}5,200 \\
2,610 \\
3,850 \\
4,250 \\
3,240 \\
3,150 \\
3,850 \\
5,780 \\
5,110 \\
5,870 \\
6,730 \\
5,200 \\
6,050 \\
6,930 \\
5,780\end{array}$ & $\begin{array}{r}390 \\
100 \\
230 \\
230 \\
120 \\
90 \\
220 \\
420 \\
390 \\
480 \\
640 \\
400 \\
520 \\
670 \\
480\end{array}$ & $\begin{array}{r}7,400 \\
4,160 \\
4,350 \\
4,340 \\
2,220 \\
4,160 \\
5,450 \\
7,910 \\
7,310 \\
9,140 \\
12,080 \\
7,520 \\
9,750 \\
15,880 \\
10,160\end{array}$ & $\begin{array}{l}2-1 / 2 \\
1 \\
2-1 / 4 \\
2-1 / 2 \\
1-1 / 4 \\
1-1 / 2 \\
2 \\
3 \\
3 \\
3 \\
3-1 / 2 \\
2-1 / 2 \\
3 \\
3 \\
3\end{array}$ \\
\hline \multicolumn{11}{|c|}{ General Territory } \\
\hline $\begin{array}{r}15 \\
17 \\
21 \\
38 \\
3 \\
39 \\
31 \\
16 \\
29 \\
19 \\
51 \\
30 \\
24 \\
7 \\
12 \\
10 \\
2\end{array}$ & $\begin{array}{l}\text { Oswego, NY } \\
\text { Rochester, NY } \\
\text { Pottstown, PA } \\
\text { Shickshinny, PA } \\
\text { Shippingport, PA } \\
\text { Middletown, PA } \\
\text { Peach Bottom, PA } \\
\text { Toms River, NJ } \\
\text { Toms River, NJ } \\
\text { Bordentown, NJ } \\
\text { Charlevoix, MI West } \\
\text { South Haven, MI } \\
\text { Midland, MI } \\
\text { Benton Harbor, MI } \\
\text { Monroe, MI } \\
\text { Oak Harbor, OH } \\
\text { Bailey Town, IN } \\
\text { (Gary) }\end{array}$ & $\begin{array}{l}B \\
B \\
O R \\
O R \\
B \\
B \\
B \\
O R \\
B \\
\text { OR } \\
\text { Val ley, NY } \\
B \\
\text { OR } \\
B \\
\text { OR } \\
B \\
\text { OR }\end{array}$ & $\begin{array}{l}\text { PC } \\
P C \\
\text { RDG } \\
\text { EL } \\
? \\
P C \\
M P A \\
C N J \\
\text { CNJ } \\
\text { PC } \\
\text { CO } \\
\text { CO } \\
\text { CO } \\
\text { CO } \\
\text { PC } \\
\text { NW } \\
\text { CSS }\end{array}$ & $\begin{array}{l}4.24 \\
4.17 \\
3.23 \\
3.64 \\
3.87 \\
3.42 \\
3.42 \\
3.67 \\
3.64 \\
3.64 \\
2.89 \\
4.17 \\
3.23 \\
4.17 \\
2.87 \\
3.92 \\
3.05\end{array}$ & $\begin{array}{l}3.97 \\
3.91 \\
3.03 \\
3.39 \\
3.64 \\
3.22 \\
3.22 \\
3.42 \\
3.39 \\
3.39 \\
2.69 \\
3.91 \\
3.03 \\
3.91 \\
2.69 \\
3.63 \\
2.95\end{array}$ & $\begin{array}{r}10,180 \\
10,010 \\
7,750 \\
8.740 \\
9,290 \\
8,210 \\
8,210 \\
8,810 \\
8,740 \\
8,740 \\
6,940 \\
10,010 \\
7,750 \\
10,010 \\
6,890 \\
9,410 \\
7,320\end{array}$ & $\begin{array}{l}8,930 \\
8,800 \\
6,820 \\
7,630 \\
8,190 \\
7,240 \\
7,240 \\
7,700 \\
7,630 \\
7,630 \\
6,050 \\
8,800 \\
6,820 \\
8,800 \\
6,050 \\
8,280 \\
6,640\end{array}$ & $\begin{array}{r}1,070 \\
1,040 \\
650 \\
810 \\
890 \\
740 \\
730 \\
820 \\
810 \\
790 \\
860 \\
1,060 \\
640 \\
1,030 \\
530 \\
1,090 \\
560\end{array}$ & $\begin{array}{l}21,380 \\
20,760 \\
13,160 \\
16,120 \\
17,880 \\
14,740 \\
14,660 \\
16,460 \\
16,220 \\
15,860 \\
17,750 \\
20,624 \\
12,771 \\
19,980 \\
10,490 \\
21,840 \\
12,600\end{array}$ & $\begin{array}{l}8-1 / 2 \\
8-1 / 2 \\
7-1 / 4 \\
8-1 / 4 \\
8-1 / 2 \\
6-1 / 2 \\
6-1 / 2 \\
9-1 / 4 \\
8-1 / 2 \\
9-1 / 4 \\
\text { n.d. } \\
\text { n.d. } \\
\text { n.d. } \\
\text { n.d. } \\
6-1 / 2 \\
4-1 / 2 \\
\text { n.d. }\end{array}$ \\
\hline \multicolumn{11}{|c|}{ New England Territory } \\
\hline $\begin{array}{l}22 \\
42 \\
25\end{array}$ & $\begin{array}{l}\text { Portland, ME } \\
\text { Vernon, VT } \\
\text { Hartford, CT }\end{array}$ & $\begin{array}{l}\mathrm{B} \\
\mathrm{B} \\
\mathrm{B}\end{array}$ & $\begin{array}{l}\text { MEC } \\
C V \\
P C\end{array}$ & $\begin{array}{l}4.62 \\
4.24 \\
4.14\end{array}$ & $\begin{array}{l}4.33 \\
3.97 \\
3.87\end{array}$ & $\begin{array}{r}11,090 \\
10,180 \\
9,940\end{array}$ & $\begin{array}{l}9,740 \\
8,930 \\
8,710\end{array}$ & $\begin{array}{l}1,230 \\
1,060 \\
1,000\end{array}$ & $\begin{array}{l}24,500 \\
21,240 \\
19,940\end{array}$ & $\begin{array}{l}8-1 / ? \\
8-1 / 2 \\
B-1 / 2\end{array}$ \\
\hline
\end{tabular}

(a) Listed freight rates and charges and special train charges include all increases through $x-318$.

(b) The Eastern railroads do not participate in these tariffs and require that the movement of spent nuclear fuel elements be conducted under contract. Thus, the listed freight rates and charges and special train charges may not be applicable for the Eastern railroads.

(c) Assume: Class 40 minimum net weight $=240,0001 \mathrm{~b}$; Class $37-1 / 2$ minimum net weight $=225,0001 \mathrm{~b}$.

(d) Regular train transit times listed for General and New England territories are preliminary estimates. All data were obtained from direct contact with railroad companies. 


\section{APPENDIX B}

FREIGHT TRAIN ACCIDENT DATA 


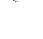


TABLE B-1. Number of Freight Train Collision Accidents by Year and by Train Speed (Class I Line Haul Railroads)

\begin{tabular}{|c|c|c|c|c|c|}
\hline \multirow{2}{*}{$\begin{array}{c}\text { Train Speed } \\
(\mathrm{mph})\end{array}$} & \multirow[b]{2}{*}{1972} & \multirow[b]{2}{*}{1973} & \multirow[b]{2}{*}{1974} & \multicolumn{2}{|c|}{ Total } \\
\hline & & & & Number & Percent \\
\hline $0-9$ & 299 & 339 & 288 & 926 & 64.5 \\
\hline $10-19$ & 88 & 108 & 89 & 285 & 19.8 \\
\hline $20-29$ & 40 & 41 & 24 & 105 & 7.3 \\
\hline $30-39$ & 14 & 20 & 17 & 51 & 3.6 \\
\hline $40-49$ & 8 & 16 & 15 & 39 & 2.7 \\
\hline $50-59$ & 4 & 5 & 7 & 16 & 1.1 \\
\hline $60-69$ & 3 & 5 & 4 & 12 & 0.8 \\
\hline $70-79$ & 0 & 0 & 1 & 1 & 0.1 \\
\hline $80-89$ & 0 & 0 & 0 & 0 & - \\
\hline Unknown & $\underline{0}$ & $\underline{0}$ & 1 & 7 & 0.1 \\
\hline Totals & 456 & 534 & 446 & 1436 & 100.0 \\
\hline
\end{tabular}

TABLE B-2. Number of Freight Train Derailment Accidents by Year and by Train Speed (Class I Line Haul Railroads)

\begin{tabular}{|c|c|c|c|c|c|}
\hline \multirow{2}{*}{$\begin{array}{c}\text { Train Speed } \\
\text { (mph) }\end{array}$} & \multirow[b]{2}{*}{1972} & \multirow[b]{2}{*}{1973} & \multirow[b]{2}{*}{1974} & \multicolumn{2}{|c|}{ Total } \\
\hline & & & & Number & Percent \\
\hline $0-9$ & 1,312 & 1,826 & 1,960 & 5,098 & 35.5 \\
\hline $10-19$ & 893 & 1,307 & 1,410 & 3,610 & 25.1 \\
\hline $20-29$ & 636 & 792 & 952 & 2,380 & 16.6 \\
\hline $30-39$ & 375 & 506 & 581 & 1,462 & 10.2 \\
\hline $40-49$ & 308 & 390 & 413 & 1,111 & 7.7 \\
\hline $50-59$ & 158 & 163 & 197 & 518 & 3.6 \\
\hline $60-69$ & 70 & 61 & 47 & 178 & 1.2 \\
\hline $70-79$ & 6 & 4 & 9 & 19 & 0.1 \\
\hline $80-89$ & 1 & 1 & 0 & 2 & -- \\
\hline Unknown & 1 & $\underline{0}$ & 2 & 3 & -- \\
\hline Totals & 3,760 & 5,050 & 5,571 & 14,381 & 100.0 \\
\hline
\end{tabular}


TABLE B-3. Number of Other Freight Train Accidents by Year and by Train Speed (Class I Line Haul Railroads)

\begin{tabular}{|c|c|c|c|c|c|}
\hline \multirow{2}{*}{$\begin{array}{c}\text { Train Speed } \\
\text { (mph) }\end{array}$} & \multirow[b]{2}{*}{1972} & \multirow[b]{2}{*}{1973} & \multirow[b]{2}{*}{1974} & \multicolumn{2}{|c|}{ Total } \\
\hline & & & & Number & Percent \\
\hline $0-9$ & 70 & 74 & 62 & 206 & 15.4 \\
\hline $10-19$ & 51 & 49 & 56 & 156 & 11.7 \\
\hline $20-29$ & 75 & 79 & 83 & 237 & 17.7 \\
\hline $30-39$ & 86 & 73 & 85 & 244 & 18.3 \\
\hline $40-49$ & 96 & 78 & 73 & 247 & 18.5 \\
\hline $50-59$ & 47 & 61 & 56 & 164 & 12.3 \\
\hline $60-69$ & 26 & 30 & 16 & 72 & 5.4 \\
\hline $70-79$ & 6 & 2 & 0 & 8 & 0.6 \\
\hline $80-89$ & 0 & 0 & 0 & 0 & -- \\
\hline Unknown & $\underline{0}$ & 1 & 1 & 2 & 0.1 \\
\hline Totals & 457 & 447 & 432 & 1336 & 100.0 \\
\hline
\end{tabular}


TABLE B-4. Number of Accidents as a Function of Train Speed for Various Dollar Damage Categories (Freight Train Accidents on Class I Line Haul Railroads, 1972-1974)

\begin{tabular}{|c|c|c|c|c|c|c|c|c|}
\hline \multirow[b]{2}{*}{ Train Speed } & \multicolumn{2}{|c|}{$>\$ 750$ Damage } & \multicolumn{2}{|c|}{$>\$ 75,000$ Damage } & \multicolumn{2}{|c|}{$>\$ 150,000$ Damage } & \multicolumn{2}{|c|}{$>\$ 250,000$ Damage } \\
\hline & $\begin{array}{l}\text { Number of } \\
\text { Accidents }\end{array}$ & $\begin{array}{l}\text { Percent of } \\
\text { Accidents }\end{array}$ & $\begin{array}{l}\text { Number of } \\
\text { Accidents }\end{array}$ & $\begin{array}{l}\text { Percent of } \\
\text { Accidents }\end{array}$ & $\begin{array}{l}\text { Number of } \\
\text { Accidents }\end{array}$ & $\begin{array}{l}\text { Percent of } \\
\text { Accidents }\end{array}$ & $\begin{array}{l}\text { Number of } \\
\text { Accidents }\end{array}$ & $\begin{array}{l}\text { Percent of } \\
\text { Accidents }\end{array}$ \\
\hline $0-9 \mathrm{mph}$ & 6232 & 36.3 & 28 & 2.4 & 10 & 1.9 & 6 & 2.6 \\
\hline $10-19 \mathrm{mph}$ & 4052 & 23.6 & 81 & 6.9 & 23 & 4.4 & 9 & 3.9 \\
\hline $20-29 \mathrm{mph}$ & 2724 & 15.9 & 218 & 18.5 & 64. & 12.4 & 20 & 8.7 \\
\hline $30-39 \mathrm{mph}$ & 1758 & 10.3 & 310 & 26.3 & 107 & 20.7 & 42 & 18.3 \\
\hline $40-49 \mathrm{mph}$ & 1397 & 8.1 & 312 & 26.4 & 169 & 32.7 & 79 & 34.5 \\
\hline $50-59 \mathrm{mph}$ & 698 & 4.1 & 165 & 14.0 & 97 & 18.8 & 47 & 20.5 \\
\hline $60-69 \mathrm{mph}$ & 262 & 1.5 & 60 & 5.1 & 45 & 8.7 & 24 & 10.5 \\
\hline $70-79 \mathrm{mph}$ & 28 & 0.2 & 3 & 0.3 & 1 & 0.2 & 1 & 0.5 \\
\hline$>80 \mathrm{mph}$ & 2 & -- & 1 & 0.1 & 1 & 0.2 & 1 & 0.5 \\
\hline TOTALS & 17153 & 100.0 & 1178 & 100.0 & 517 & 100.0 & 229 & 100.0 \\
\hline
\end{tabular}


TABLE B-5. Distribution of Freight Train Collision Accidents by Subclass and Train Speed (Class I Line Haul Railroads, 1972-1974)

\begin{tabular}{|c|c|c|c|c|c|c|c|c|c|c|c|c|c|c|c|c|}
\hline \multirow{2}{*}{$\begin{array}{l}\text { Train } \\
\text { Speed } \\
\text { (mph) }\end{array}$} & \multicolumn{2}{|c|}{ Rear-End } & \multicolumn{2}{|c|}{ Head-On } & \multicolumn{2}{|c|}{ Broken-Train } & \multicolumn{2}{|c|}{$\begin{array}{l}\text { Sice or } \\
\text { raking }\end{array}$} & \multicolumn{2}{|c|}{ Crossing } & \multicolumn{2}{|c|}{$\begin{array}{c}\text { Trains with Cars } \\
\text { not in Trains }\end{array}$} & \multicolumn{2}{|c|}{ Switching } & \multicolumn{2}{|c|}{$\begin{array}{l}\text { Not El sewhere } \\
\text { Classifiable }\end{array}$} \\
\hline & Number & Fraction & Number & Fraction & Numer & Fraction & Numider & Fraction & Number & Fraction & iumber & Fraction & Number & Fraction & Number & Fraction \\
\hline $0-9$ & 39 & 0.348 & 18 & 0.290 & 11 & 0.083 & 69 & 0.711 & 2 & 0.333 & 25 & 0.510 & 723 & 0.795 & 39 & 0.591 \\
\hline $10-19$ & 41 & 0.365 & 25 & 0.403 & 27 & 0.203 & 14 & 0.144 & 2 & 0.333 & 13 & 0.265 & 147 & 0.162 & 16 & 0.242 \\
\hline $20-29$ & 17 & 0.152 & 9 & 0.145 & 36 & 0.271 & 8 & 0.082 & 1 & 0.167 & 4 & 0.082 & 24 & 0.027 & 6 & 0.091 \\
\hline $30-37$ & 10 & 0.089 & 7 & 0.113 & 19 & 0.143 & 3 & 0.031 & 0 & & 5 & 0.102 & 6 & 0.007 & 1 & 0.015 \\
\hline $40-49$ & 2 & 0.018 & 2 & 0.032 & 21 & 0.158 & 1 & 0.011 & 1 & 0.167 & 2 & 0.041 & 7 & 0.008 & 3 & 0.045 \\
\hline $50-59$ & 1 & 0.009 & 1 & 0.016 & 12 & 0.090 & 1 & 0.011 & 0 & & 0 & & 0 & & 1 & 0.015 \\
\hline $60-69$ & 2 & 0.018 & 0 & 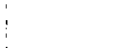 & 7 & 0.053 & 0 & & 0 & & 0 & & 3 & & 0 & \\
\hline $70-79$ & 0 & & 0 & $\vdots$ & 0 & & 1 & 0.010 & 0 & & 0 & & 0 & & 0 & \\
\hline $80-89$ & 0 & & 0 & ; & 0 & & 0 & & 0 & & 0 & & 0 & & 0 & \\
\hline L'nknown & & & & 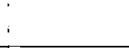 & & & & & & & & & 1 & 0.001 & & \\
\hline Totals & 112 & & 62 & & 133 & & 97 & & 6 & & 49 & & 911 & & 66 & \\
\hline$\leq 35 \mathrm{mph}$ & 102 & 0.971 & 56 & 0.903 & 84 & 0.632 & 93 & 0.959 & 5 & 0.833 & 45 & 0.918 & 898 & 0.986 & 62 & 0.939 \\
\hline$>35 \mathrm{mph}$ & 10 & 0.089 & 6 & 0.097 & 49 & 0.368 & 4 & $0.04 i$ & 7 & 0.167 & 4 & 0.082 & 13 & 0.014 & 4 & 0.061 \\
\hline
\end{tabular}




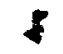

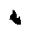

APPENDIX C

TRAINS - COMPUTER CODE FOR ECONOMIC ANALYSIS 
This program basically determines a lowest-cost, multiple-cask shipping configuration for each reactor and calculates the freight charges, special train charges and cask use charges for this configuration. These charges are then summed and averaged for all reactors shipping to a given reprocessor to develop the average charge per kilogram of spent fuel shipped. The program prints out:

(1) The number of trips made to each reactor and the number of casks carried on each trip.

(2) The total costs in dollars for freight charges, special train charges and cask use charges associated with each annual reactor pickup.

(3) The unit charges in dollars per kilogram for the above.

(4) The total cask-days required to serve each reactor.

(5) The number of casks required by each reprocessor serving the system in a year's time.

(6) The total and average unit costs for each reprocessor.

A set of tables showing the program output for the reference case are given in Appendix A.

The cost algorithms used to compute costs are shown in Equations (1), (2) and (3) for one trip from Reactor $i$ to Reprocessor $j$.

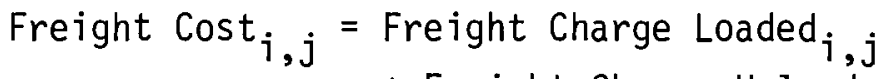

$$
\begin{aligned}
& + \text { Freight Charge Untoaded }_{i, j}
\end{aligned}
$$

Cask Use Cost $=$ Cask Use Charge Per Day $\times$ Cask-Days 
The total cost to service Reactor $j$ is given by:

$$
\begin{aligned}
& \text { Cost for Reactor } j=\frac{\text { Spent Fue }_{j}}{\text { Cask Payload }_{m}} \text { Freight Cost }_{i, j} \\
& +\frac{{\text { Special Train } \text { Cost }_{i, j}}_{\text {Number Cask-Trips }}}{\text { Nusk Use Cost }}+\text { Cas }_{j}
\end{aligned}
$$

where

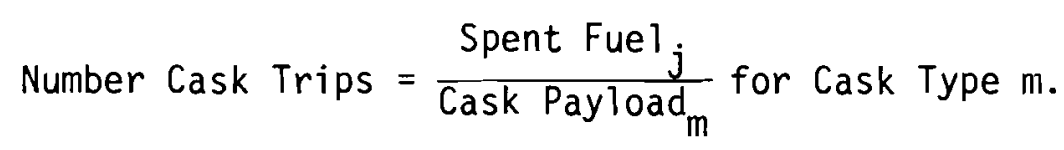

The total cost for Reprocessor $j$ is calculated somewhat differently using Equations (1), (2) and (3) and the number of trips, $k$. This is because yearly rental or ownership of casks is assumed and, therefore, cask use costs are a function of total casks in use in the reprocessor's system during the year rather than strictly a function of the number of days the casks are used (as would be calculated for individual reactors). In other words, total reprocessor costs are not simply the sum of reactor costs, but will probably include some slack time for which the reprocessor would be charged, but during which the casks would not be in use. The equation for calculation of total reprocessor costs is:

$$
\begin{aligned}
\text { Total Cost } \mathrm{j}_{j}= & \sum_{i=1}^{N_{0}} \sum_{k=1}^{T}\left[\left(\text { Freight Cost Per Trip } p_{i}\right)\right. \\
& \times \text { Number of Casks Carried Per Trip } \\
& + \text { Special Train Costs Per Trip } i] \\
& + \text { Cask Use Charge Per Day } \times \text { Number of Casks in } \\
& \text { Reprocessor System } \times \text { Number of Days Cask Can } \\
& \text { Be Used Per Year. }
\end{aligned}
$$

where

$$
\begin{aligned}
N_{0} & =\text { Number of Reactors } i \text { serviced by Reprocessor } j . \\
T & =\text { Number of trips made to Reactor } i .
\end{aligned}
$$


One additional complication to the above equation not shown here is that different sized casks are used to service different reactors in the Barnwe 11 system since intermodal train and truck casks are required for some reactors because of lack of railheads. 
APPENDIX D

RAILROAD CHARGES APPLICABLE TO SHIPMENT

OF SPENT NUCLEAR FUEL ELEMENTS 
SPECIAL CAR AND CASK COMBINATION CHARGES $^{(a)}$

(A) Loaded: (1) Item 80762, Uniform Freight Classification 12 (UFC-12)

Declared Valuation less than $\$ 0.40 / 1 b$ - Class 40 Rate

Declared Valuation $\$ 0.40$ to $\$ 1.00 / 1 b$ - Class 70 Rate

Declared Valuation $\$ 1.00$ to $\$ 5.00 / 1 b$ - Class 85 Rate

(2) Item $80768 \mathrm{~A}$, Note 3, UFC-12

Eastern railroads flag out of tariff and require

special contract.

(3) Item $80769 \mathrm{~A}$, Note 4 , UFC-12

Class rates apply against minimum net weight of

$240,0001 \mathrm{~b}$ for each car.

(a) Source: Tariff Publishing Officer, LIFC-12, Chicago, IL.

ASSUME: Loaded - Class 40 rates apply

240,000 1b/car minimum

Special train required (S.T. charges additive to Class 40 freight charges)

Eastern railroads do not participate in these tariffs and rates and require special contract. Thus, the listed freight rates and charges and special train charges may not be directly applicable for the Eastern railroads.

Unloaded - Class $37-1 / 2$ rates apply 225,000 1b/car minimum

Special train not required

Eastern railroads are not flagged out

QUALIFICATION: Staff members of a number of Eastern and Western roads indicated that the return trip must also be by special train and that AAR supports this position. Among the staff members of Eastern and Western roads interviewed, this position was not unanimous. Pressure may be applied to require this in the future. 
(4) I tem 80769.5 , Note 5 , UFC-12

Class rates are only applicable on shipments moving in special freight train service subject to provisions of applicable special freight train service tariffs.

(B) Unloaded: (1) I tem 81295B, UFC-12

(Return

Cars shipping radioactive materials moved on own

Trip) whee1s. Class $37-1 / 2$. Subject to $225,000-1 \mathrm{~b}$ minimum for each car.

(2) Item $81297 \mathrm{~B}$, Note $5-1 / 2$, UFC-12

Contains further description of car and cask combination.

SPECIAL TRAIN RATES (a)

(INCLUDE ALL INCREASES THROUGH $X-318$ )

SOUTHERN TERRITORY

$\$ 18.93 /$ train-mile (all Southern Roads)

110 miles minimum for each railroad involved in movement

\section{WESTERN TERRITORY}

$\$ 19.32 /$ train-mile (a11 Western Roads)

$\$ 2120$ (i.e., 2110 miles) minimum for each railroad involved in movement.

(a) Special train charges are additive to freight charges. 


\section{DISTRIBUTION}

No. of

Copies

\section{OFFSITE}

A. A. Churm

Chicago Patent Group

Chicago Operations Office

9800 South Cass Avenue

Argonne, IL 60439

27 DOE Technical Information Center

K. A. Trickett

Division of Reactor Development and Demonstration

Department of Energy

Germantown, MD 20014

W. Brobst

Division of Environmental Control Technology

Transportation Branch

Department of Energy

Washington, DC 20545

M. Chais

Division of Environmental Control Technology

Transportation Branch

Department of Energy

Washington, DC 20545

R. Garrison

Division of Environmental Control Technology

Transportation Branch

Department of Energy

Washington, DC 20545

R. B. Chitwood

Waste Management Division

Department of Energy

Washington, DC 20545
No. of

Copies

J. A. Sisler

Division of Environmental

Control Technology

Transportation Branch

Department of Energy

Washington, DC 20545

R. M. Moser

DOE Chicago Operations Office

9800 South Cass Avenue

Argonne, IL 60439

L. L. Turner

DOE Savannah River Operations Office

P.0. Box A

Aiken, SC 29801

D. Davis

DOE Albuquerque Operations Office P.0. Box 5400

Albuquerque, NM 87115

J. A. Lamb

DOE Oak Ridge Operations Office P.0. Box E

Oak Ridge, TN 37830

J. J. Schreiber

DOE Oak Ridge Operations Office

P.0. Box E

Oak Ridge, TN 37830

R. C. Dove

University of California

Los Alamos Scientific Laboratory

P. 0. Box 1663

Los Alamos, NM 87545

T. K. Keenan

University of Cal ifornia

Los Alamos Scientific Laboratory

P. 0. Box 1663

Los Alamos, NM 87545 
No. of

Copies

T. A. Butler

University of California

Los Alamos Scientific Laboratory

P. 0. Box 1663

Los Alamos, NM 87545

\section{Benner \\ National Transportation \\ Safety Board \\ Washington, DC 20594}

J. Power

Westinghouse Electric Corp.

P.0. Box 355

Pittsburgh, PA 15230

P. J. Eicker

Sandia Laboratories, Livermore

Livermore, CA 94550

J. W. Langhaar

E. I. Dupont de Nemours \& Company

Savannah River Plant

Aiken, SC 29801

3 Department of Transportation

Materials Transportation Bureau

2100 Second St. S.W.

Washington, DC 20590

H. Thompson

Battelle Memorial Institute

Washington Operations

2030 M. St. NW

Washington, DC 20545

W. Rowe

Environmental Protection Agency

401 M. Street

Washington, DC 20460

A. J. Nertney

Aerojet Nuclear Company

550 2nd St.

Idaho Falls, ID 83401
No. of

Copies

C. Starr

Electrical Power Research Inst.

P. 0. Box 10412

Palo Alto, CA 94304

C. Comar

Electrical Power Research Inst.

P. 0. Box 10412

Palo Alto, CA 94304

Mary Anne Lauderdale

SSI

560 San Antonio Rd, Suite 204

Palo Alto, CA 94306

E. Zebrowski

Electrical Power Research Inst.

P.0. Box 10412

Palo Alto, CA 94304

R. Williams

Electrical Power Research Inst.

P. 0. Box 10412

Palo Alto, CA 94304

Combustion Engineering, Inc.

Windsor, CT 06095

J. Desmond

Babcock \& Wilcox, Co.

P.0. Box 1260

Lynchburg, VA 24505

C. Woods

Babcock \& Wilcox Co.

P.0. Box 1260

Lynchburg, VA 24505

Prof. Norman C. Rasmussen

Massachusetts Institute of

Technology

Cambridge, MA 02139

L. Bonzon

Sandia Laboratories

P. 0. Box 5800

Albuquerque, NM 87115 
No. of

Copies

J. K. Cole

Sandia Laboratories

P. 0. Box 5800

Albuquerque, NM 87115

J. T. Foley

Sandia Laboratories

P. 0. Box 5800

Albuquerque, NM 87115

J. Freedman

Sandia Laboratories

P. 0. Box 5800

A1buquerque, NM 87115

W. F. Hartmann

Sandia Laboratories

P. 0. Box 5800

Albuquerque, NM 87115

R. M. Jefferson

Sandia Laboratories

P. 0. Box 5800

Albuquerque, INM 87115

R. Luna

Sandia Laboratories

P. 0. Box 5800

Albuquerque, NM 87115

T. G. Priddy

Sandia Laboratories

P. 0. Box 5800

A1buquerque, NM 87115

A. W. Snyder

Sandia Laboratories

P. 0. Box 5800

Albuquerque, NM 87115

R. Yoshimura

Sandia Laboratories

P. 0. Box 5800

Albuquerque, NM 87115
No. of

Copies

R. F. Barker

Nuclear Regulatory Commission

Washington, DC 20555

C. B. Bartlett

Nuclear Regulatory Commission

Washington, DC 20555

C. E. MacDonald

Nuclear Regulatory Commission Washington, DC 20555

D. A. Nussbaumer

Nuclear Regulatory Commission Washington, DC 20555

M. J. Steindler

Argonne National Laboratory

9700 South Cass Avenue

Argonne, IL 60439

S. J. Basham

Battelle Memorial Insititute

Columbus Operations

505 King Avenue

Columbus, $\mathrm{OH} 43201$

R. A. Robinson

Battelle Memorial Institute

Columbus Operations

505 King Avenue

Columbus, $\mathrm{OH} 43201$

W. L. Goodwin

Manger, R\&E Services

Westinghouse Nuclear Fuels

Division

P. 0. Drawer R

Columbia, SC 29250

A. L. Kaplan

General Electric Co.

Nuclear Fuel Division

P. 0. Box 780

Wilmington, NC 28401 
No. of

Copies

G. Lapier

Babcock \& Wilcox Co.

Apo 110, PA 15613

J. G. Crawford

Goodyear Atomic Corp.

P. 0. Box 628

Piketon, $\mathrm{OH} 45661$

J. 0. Blomeke

Union Carbide Corporation

Oak Ridge National Laboratories

P. 0. Box $X$

Oak Ridge, TN 37830

R. D. Seagren

Union Carbide Corporation

Oak Ridge National Laboratories

P. 0. Box $X$

Oak Ridge, TN 37830

L. B. Shappert

Union Carbide Corporation

Oak Ridge National Laboratories

P. 0. Box $X$

Oak Ridge, TN 37830

J. Duckworth

Nuclear Fuel Service, Inc.

P.0. Box 124

West Valley, NY 14171

W. A. 01dham

Nuclear Fuel Service, Inc.

P.0. Box 124

West Valley, NY 14171

G. L. Stukenbroker

$N$ L Industries, Inc.

Nuclear Transportation Dept.

919 Market St., Suite 1701

Wilmington, DE 19801
No. of

Copies

H. G. Shealy

Bureau of Radiological Health

South Carolina Department of Health and Environmental Control

Columbia, SC 29405

J. S. Corbett

ChemNuclear Systems, Inc.

P. 0. Box 1866

Bellevue, WA 98009

P. T. Tuite

Hittman Nuclear and Development Corporation

9190 Red Branch Rd.

Columbia, MD 21045

S. Williamson

Nuclear Engineering Co.

P.0. Box 4308

Walnut Creek, CA 94596

J. Edlow

Edlow International Inc.

1100 17th St. N.W., Suite 404

Washington, DC 20036

L. Rutland

ATCOR, Inc.

Park Mal1

Peekski11, Ny 10566

D. A. Edling

Mound Laboratories

P.0. Box 32

Miamisburg, $\mathrm{OH} 45342$

J. W. Doty

Mound Laboratories

P.0. Box 32

Miamisburg, $\mathrm{OH} 45342$ 
No. of

Copies

D. Okrent

Department of Engineering and

Applied Science

University of California

Los Angeles, CA 90024

2 L. Forrest

California Energy Resources

Conservation and Development

Commission

1111 Howe Avenue

Sacramento, CA 95825

M. Gordon

Atomic Industrial Forum

7101 Wiscons in Ave.

Washington, DC 20014

A. L. Babb

Department of Nuclear Engineering

Benson Hall

University of Washington

Seattle, WA 98195

W. S. Fellows

Southern Interstate Nuclear Board

One Exchange Place Suite 1230

Atlanta, GA 30341

R. M. Graziano

Association of American

Rail roads

1920 L St.

Washington, DC 20036

K. P. Furber

Association of American

Railroads

1920 L St.

Washington, DC 20036

D. G. Maxwell

$\mathrm{N}$ L Industries

Nuclear Division

Foot of West Street

Wilmington, PA 19801
No. of

Copies

W. R. Teer

Transnuclear Inc.

One N. Broadway

White Plains, NY 10601

R. S. Lowrie

Union Carbide Corporation

Office of Waste Isolation

P. D. Box $Y$

Oak Ridge, TN 37830

D. Turner

Union Carbide Corporation

Office of Waste Isolation

P. 0. Box $Y$

Oak Ridge, TN 37830

S. C. Cohen

Teknekron

4701 Sangamore Rd.

Washington, DC 20016

B. J. Garrick

Pickard, Low and Garrick, Inc. 200 Newport Center Drive

Suite 312

Newport Beach, CA 92660

L. Sennema

Health Physics Division

Ontario Hydro

P.O. Box 3000

Tiverton, Ontario

Canada

W. R. Taylor

Atomic Energy of Canada Ltd.

Chalk River Laboratories

Chalk River, Ontario KOJIJ0

Canada

M. Toml inson

White Shell Nuclear Research

Establ ishment

Pineqa, Manitoba ROE ILO

Canada 
No. of

Copies

S. A. Mayman

Fuel Recycle Waste

Management Program

Whiteshell Nuclear Research

Establ ishment

Pinewa, Manitoba ROE ILO

Canada

W. J. Shelley

Kerr-McGee Corporation

Oklahoma City, OK

R. W. Peterson

Allied General Nuclear Services

P. 0. Box 847

Barnwe11, SC 29812

A. Carson

General Electric Company

175 Curtner Avenue

San Jose, CA 95125

R. A. Koynenburg

University of California

Lawrence Livermore Laboratories

P. 0. Box 808

Livermore, CA 94551

W. E. Pollock

Oregon Department of Energy

Salem, OR 97301

Dick Moyer

E I dupont delNeumours and Co., Inc. Savanah River Laboratory

Aiken, SC 29801

K. Woods

Oregon Department of Energy

Salem, OR 97301

W. M. Rogers

Western Interstate Nuclear

Board

1300 Carr

Denver, CO 80226
No. of

Copies

G. P. Jones

University of Southern

California

University Park

Los Angeles, CA 90007

L. L. Philipson

University of Southern

California

University Park

Los Angeles, CA 90007

C. V. Hodges

Holmes \& Narver

400 E. Orangethrope Ave.

Anaheim, CA 92801

E. A. Straker

Science Applications, Inc.

P. 0. Box 2351

La Jolla, CA 92038

R. C. Erdman

Science Applications, Inc.

2680 Hanover St.

Palo Alto, CA 94304

G. Waymire

Exxon Nuclear Company, Inc.

P. 0. Box 3990

MS $8 A-68$

Seattle, WA 98124

Duncan B. Phillips

General Attorney

Southern Railway System

Washington, DC 20545

J. G. German

Vice President - Engineering

Missouri - Pacific Railroad Co.

210 N. 13th St.

St. Louis, MO 63103 
No. of

Copies

7 DOE Richland Operations Office
T. A. Bauman
W. A. Burns
R. B. Goranson
P. E. Lamont
J. M. Peterson
H. E. Ransom
D. J. Squires

3 Rockwe11 Hanford Operations
W. G. Bevan
W. M. Harty
D. D. Woodrich

3 United Nuclear Industries, Inc.

J. A. Adams

P. A. Crosetti

T. E. Dabrowski

1 Hanford Engineering Development Laboratory

A. W. DeMerschman

Battelle-Northwest
W. J. Bair
C. L. Brown
S. H. Bush
N. E. Carter
L. L. Clark
J. G. DeSteese

No. of

Copies

H. K. Elder

E. A. Eschbach

A. L. Franklin

L. 0. Foley

R. J. Hall

H. Harty

P. L. Hendrickson

H. L. Henry

J. F. Johnson

W. S. Kelly

S. N. Liu

W. V. Loscutoff

R. W. McKee

E. S. Murphy

R. E. Rhoads

J. W. Voss

E. C. Watson

R. D. Widrig

L. D. Williams

G. H. Winsor

Technical Information (5)

Technical Publications

$\underline{\text { OFFSITE }}$

2 Washington Public Power Supply System

G. F. Bailey

J. B. Vetrano

3 Exxon Nuclear Company, Inc.

R. Nilsen

R. K. Robinson

G. Waymire 


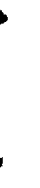

$y$

. 